Florida International University

FIU Digital Commons

$3-31-2017$

\title{
South-South Cooperation as an Alternative Development Strategy: Rethinking Development Cooperation through South-South Cooperation in Latin America and the Caribbean- Brazil and Haiti
}

Karen Elaine Clay

Florida International University, kclay001@fiu.edu

Follow this and additional works at: https://digitalcommons.fiu.edu/etd

Part of the International Relations Commons

\section{Recommended Citation}

Clay, Karen Elaine, "South-South Cooperation as an Alternative Development Strategy: Rethinking Development Cooperation through South-South Cooperation in Latin America and the Caribbean- Brazil and Haiti" (2017). FIU Electronic Theses and Dissertations. 3206.

https://digitalcommons.fiu.edu/etd/3206

This work is brought to you for free and open access by the University Graduate School at FIU Digital Commons. It has been accepted for inclusion in FIU Electronic Theses and Dissertations by an authorized administrator of FIU Digital Commons. For more information, please contact dcc@fiu.edu. 


\section{FLORIDA INTERNATIONAL UNIVERSITY}

Miami, Florida

\section{SOUTH-SOUTH COOPERATION AS AN ALTERNATIVE DEVELOPMENT STRATEGY: RETHINKING DEVELOPMENT COOPERATION THROUGH SOUTH-SOUTH COOPERATION IN LATIN AMERICA AND THE CARIBBEAN- \\ BRAZIL AND HAITI}

A dissertation submitted in partial fulfillment of

the requirements for the degree of

DOCTOR OF PHILOSOPHY

in

INTERNATIONAL RELATIONS

by

Karen Clay 
To: Dean John F. Stack

Steven J. Green School of International and Public Affairs

This dissertation, written by Karen Clay, and entitled South-South Cooperation as an Alternative Development Strategy: Rethinking Development Cooperation through SouthSouth Cooperation in Latin America and the Caribbean- Brazil and Haiti, having been approved in respect to style and intellectual content, is referred to you for judgment.

We have read this dissertation and recommend that it be approved.

Maria Willumsen

Barry Levitt

Astrid Arrarás

Eduardo Gamarra, Major Professor

Date of Defense:

The dissertation of Karen Clay is approved.

Dean John F. Stack

Steven J. Green School of International and Public Affairs

Andrés G. Gil

Vice President for Research and Economic Development and Dean of the University Graduate School

Florida International University, 2017 
(C) Copyright 2017 by Karen Clay

All rights reserved. 


\author{
ABSTRACT OF THE DISSERTATION \\ SOUTH-SOUTH COOPERATION AS AN ALTERNATIVE DEVELOPMENT \\ STRATEGY: RETHINKING DEVELOPMENT COOPERATION THROUGH \\ SOUTH-SOUTH COOPERATION IN LATIN AMERICA AND THE CARIBBEAN- \\ BRAZIL AND HAITI \\ by \\ Karen Clay
}

Florida International University, 2017

Miami, Florida

Professor Eduardo Gamarra, Major Professor

The dissertation examined the South-South cooperation as an alternative development strategy for Southern countries by targeting the collaboration between Brazil and Haiti, two countries in Latin America and the Caribbean. Examining development cooperation between Brazil and Haiti could contribute to a better understanding of the central question, why Southern countries engage in South-South cooperation?

In the context of the 2008 financial crisis and the ensuing reduction of aid coming from Global North countries to developing countries, South-South cooperation has become an alternative economic and political arrangement from the more traditional North-South framework. For this reason, South-South cooperation between emerging donors and recipients was deemed an important development for the international aid architecture as a whole. 
A combination of semi-structured interviews and survey questionnaires were conducted to capture the professional, diplomatic and political perspectives of highranking officials, leaders and experts on South-South cooperation and Latin American and Caribbean relations. The study's findings revealed that the benefits and challenges of the South-South cooperation framework does not affect development in a conclusive way. 
TABLE OF CONTENTS

CHAPTER

PAGE

CHAPTER 1 INTRODUCTION AND OVIEW OF THE STUDY .................................

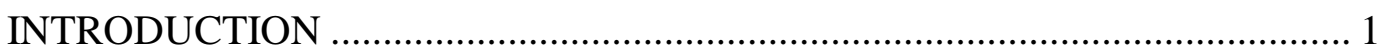

COMPLEXITY OF SOUTH-SOUTH COOPERATION …............................. 4

KEY MILESTONES AND EVENTS IN SOUTH-SOUTH COOPERATION ... 14

SIGNIFICANCE AND ASSUMPTIONS ..................................................... 35

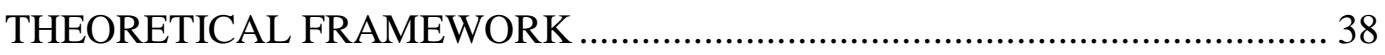

RESEARCH FRAMEWORK AND METHOD ............................................ 41

HYPOTHESIZED OUTCOME AND OVERVIEW OF DISSERTATION ........ 47

CHAPTER 2 THE EXPLANATORY FRAMEWORK …........................................49

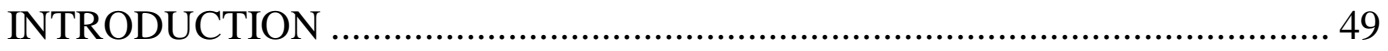

EXPLICATION OF GLOBAL SOUTH ….................................................. 50

APPROACHES TO SOUTH-SOUTH COOPERATION .................................. 55

EMERGING DONOR CHALLENGE TO THE TRADITONAL

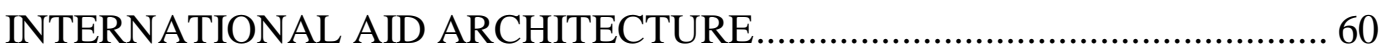

SOUTH-SOUTH COOPERATION IN LATIN AMERICA ............................... 73

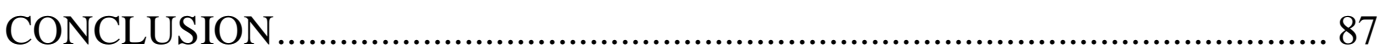

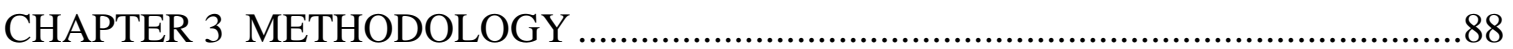

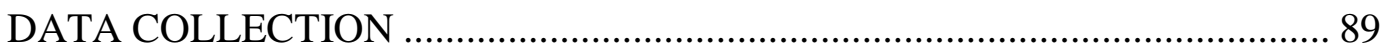

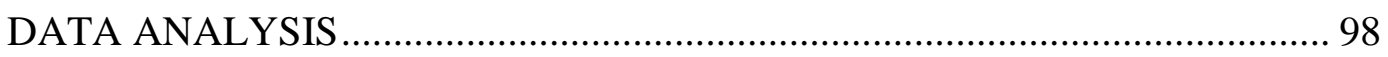

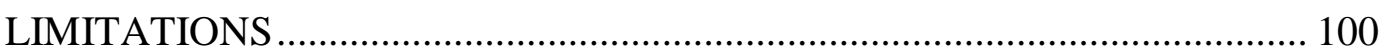

OVERVIEW OF DATA AND ANALYSIS CHAPTERS .............................. 101

CHAPTER 4 A TWIN CASE OF EXCEPTIONALISM …........................................ 102

CONTEXTUALIZING CRISIS - HAITI .................................................... 102

CONTEXTUALIZING CRISIS - BRAZIL.................................................. 107

THE RISE OF BRAZIL AS A DEVELOPMENT PROVIDER ........................ 108

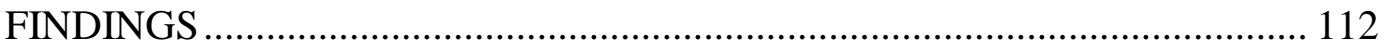

SUMMARY OF THE QUALITATIVE FINDINGS ..................................... 144 
CONCLUSION

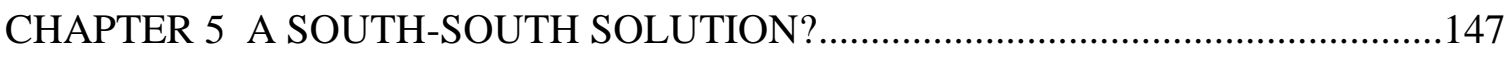

DISCUSSION OF THE QUALITATIVE FINDINGS ....................................... 149

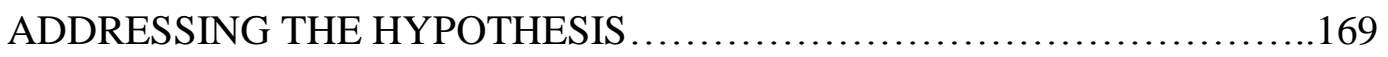

ADDRESSING THE CENTRAL QUESTION ............................................. 173

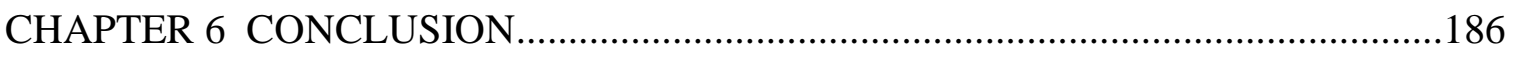

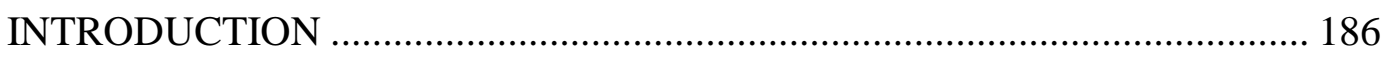

RETHINKING DEVELOPMENT COOPERATION ....................................... 190

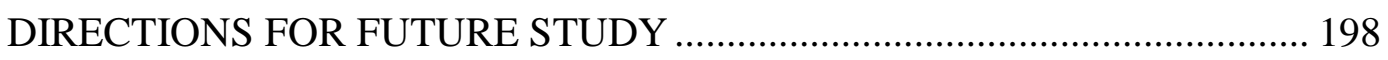

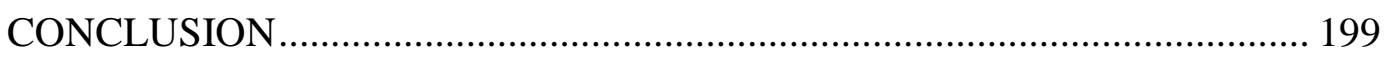

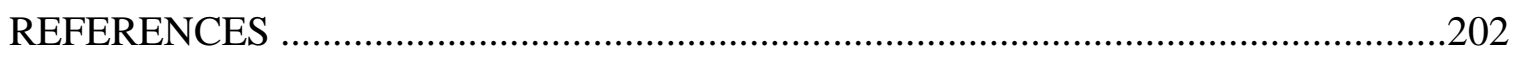

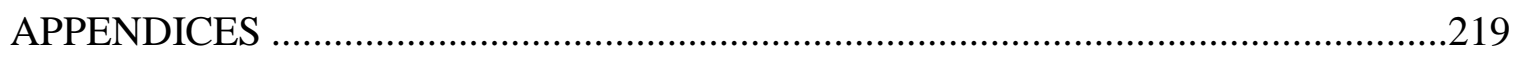

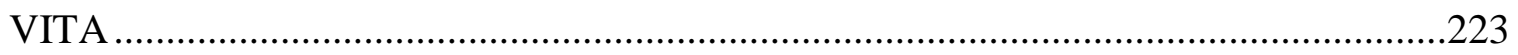




\section{LIST OF TABLES}

TABLE

PAGE

1. Structural Projects of the Brazilian Ministry of Foreign Relations in Latin America and the Caribbean (LAAC) and Africa 2000-2014.

2. Key Milestones and Events in South-South Cooperation among Regions and States of the South during the Cold War Era

3. The Ten Principles of the Bandung Conference, 1955

4. A Brief Compilation of Kwame Nkrumah's Perspectives on of Non-alignment between 1958 and 1973

5. Key Milestones and Events in South-South Cooperation during the Cold War Era within the United Nations System

6. Estimates of Gross Concessional Flows for Development Co-operation ("ODA-like" Flows) from OECD Key Partners .

7. Principles of South-South Cooperation that Guide Latin American Development Cooperation

8. Bolivarian Alliance for the Peoples of Our America - Peoples' Trade Treaty (ALBATCP)-Haiti Institutional Process and Outcome.

9. Participant Demographic

10. Foreign Invasions and Foreign Interventions into Haiti: 1914-present 104

11. Benefits of Engaging in the SSC Framework

12. Challenges from Engaging in the SSC Framework

13. Strategic Plans for Engaging in the SSC Framework 


\section{LIST OF FIGURES}

FIGURE

PAGE

1. Intended direction of the research framework. ......................................................44

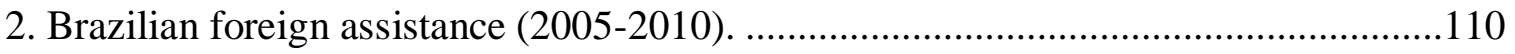

3. Graphic representation addressing the hypothesis framework. ...............................148

4. Graphic representation addressing the central question framework. .........................149

5. Directionality of the qualitative responses to the dissertation sub-questions. .............170

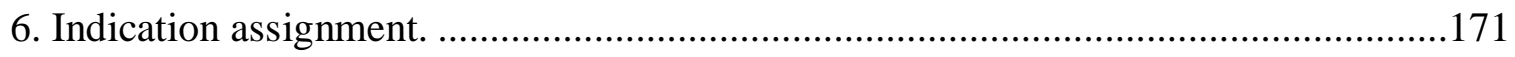

7. Graphic representation addressing the hypothesis results and outcomes. ..................173

8. Graphic representation addressing the central question....................................... 185 


\section{CHAPTER 1}

\section{$\underline{\text { INTRODUCTION AND OVIEW OF THE STUDY }}$}

\section{INTRODUCTION}

In this dissertation, emerging donor engagement in South-South cooperation was examined by targeting the collaboration between Brazil and Haiti. In the context of the 2008 financial crisis and the ensuing reduction of aid coming from Global North ${ }^{1}$ countries to developing countries, South-South cooperation has become an alternative economic and political arrangement from the more traditional North-South framework. ${ }^{2}$ Evidence for this alternative includes the growing presence of emerging donor countries

\footnotetext{
${ }^{1}$ The "Global North" pertains to a cluster of developed countries that include the United States, Japan, and European nations based on their socio-economic and political similarities See Önis, Ziya (2016). "Democracy in Uncertain Times: Inequality and Democratic Development in the Global North and Global South." METU Studies in Development, 43(1): 317-336.

${ }^{2}$ See Burges, Sean W. (2007). "Building a Global Southern Coalition: The Competing Approaches of Brazil's Lula and Venezuela's Chavez." Third World Quarterly, 28(7): 1343-1358.; de Renzio, Paolo and Seifert, Jurek (2014). "South-South Cooperation and the Future of Development Assistance: Mapping Actors and Options." Third World Quarterly, 35(10): 1860-1875; Ugwuja, Alex A., Ubaku, Kelechi C. Obiakor, Nwachukwu J. and Ibekilo, Bruno (2014). "South-South Cooperation and the Prospects of a New International Economic Order: An Insight into the India Brazil-South Africa (IBSA) Dialogue Forum." International Journal of Humanities Social Sciences and Education (IJHSSE), 1(8): 171-182; Quadir, Fahimul (2013). "Rising Donors and the New Narrative of 'South-South' Cooperation: What Prospects for Changing the Landscape of Development Assistance Programmes?" Third World Quarterly, 34(2): 321338; Stuenkel, Oliver. (May 2013). "Institutionalizing South-South Cooperation: Towards a New Paradigm? Background Research Paper Submitted to the High Level Panel on the Post-2015 Development Agenda." Accessed November 26, 2014. http://www.post2015hlp.org/wpcontent/uploads/2013/05/Stuenkel_Institutionalizing-South-South-Cooperation-Towards-a-NewParadigm.pdf; Gore, Charles (2013). "The New Development Cooperation Landscape: Actors, Approaches, Architecture.” Journal of International Development, 25(6): 769-786.
} 
such as the BRICS (Brazil, Russia ${ }^{3}$, China, India, and South Africa) within the global aid architecture, providing assistance to other developing countries. ${ }^{4}$

As an alternative strategy for the development of countries of the Global South ${ }^{5}$, the impact of South-South cooperation has largely been defined as too small to entirely replace Northern assistance; at best, it may only complement North-South cooperation. ${ }^{6}$ This overall understanding is based on a gap in the available data on development cooperation activities between Southern countries including the amount, quality, and types of development assistance exchanged among them. ${ }^{7}$ Southern actors do not follow traditional reporting, evaluation, and assessment mechanisms; consequently, very little is known about development results from South-South cooperation. ${ }^{8}$

To address this gap in knowledge about South-South assistance in the context of dwindling aid from the Global North ${ }^{9}$ and activism among developing countries in the

\footnotetext{
${ }^{3}$ For the purpose of the dissertation Russia as a country of the North will not be defined as an emerging donor country.

${ }^{4}$ IBON International (2014). Ibon Primer on South-South Cooperation. IBON International. Quezon City, Philippines: IBON International. Accessed November 16, 2015. http://iboninternational.org/resources/14/05/13/ibon-primer-south-south-cooperation; Woods, Ngaire (2008). "Whose Aid? Whose Influence? China, Emerging Donors and the Silent Revolution in Development Assistance." International Affairs, 84(6): 1205-1221.

5 The "Global South" pertains to a cluster of developing countries that include nations in Africa, Latin America, and parts of Asia based on their socio-economic and political similarities (Önis, 2016).

${ }^{6}$ Stuenkel (2013).

${ }^{7}$ Gray, Kevin and Gills, Barry K. (2016). "South-South Cooperation and the Rise of the Global South." Third World Quarterly, 37(4): 557-574.

${ }^{8}$ Quadir, (2013).

${ }^{9}$ Abdenur, Adriana Erthal and Marques Da Fonseca, João Moura Estevão (2013). “The North's Growing Role in South-South Cooperation: Keeping the Foothold.” Third World Quarterly, 34(8): 1475-1491.
} 
area of development cooperation, this dissertation aimed to examine the overall cooperation framework between Southern countries through the central question of why Southern countries engage in South-South cooperation. To answer the question, I explored South-South cooperation as an alternative development strategy in Latin America and the Caribbean (LAC). The specific goal of this research was to analyze the impact including the benefits, challenges, and strategic rationale of a South-South cooperation framework (SSC framework) comprised of agreements, statements, rhetoric and actions of two countries. I took the case study approach through the application of the SSC framework to two select countries in the LAC region: Brazil and Haiti.

Yiping Zhou, Director of the Special Unit for South-South Cooperation in United Nations Development UNDP speaking to the OECD meeting of National Focal Points for Policy Coherence for Development argues for the need to define the aspects of SouthSouth relations, including South-South trade, South-South investment, South-South technology transfers, and South-South development cooperation in order to understand South-South cooperation. ${ }^{10}$ However, Partners in Population and Development —an inter-governmental organization for promoting South-South cooperation-has chosen to approach South-South cooperation as an "international development strategy."11 This dissertation placed importance on examining South-South cooperation as an international

\footnotetext{
${ }^{10}$ Zhou, Yiping (October 2010). The Future of South-South Development Assistance and the Role of the $U N$. Speech presented to the OECD Meeting of National Focal Points for Policy Coherence for Development, Paris, France. Accessed June 11, 2014. http://www.oecd.org/development/pcd/46188961.pdf.
}

${ }^{11}$ Partners in Population Development. (n.d.). Chapter 1. South-South cooperation: A Pathway for Development. Accessed on November 20, 2014. http://www.partners-popdev.org/publication/ppdhandbook/, 3 . 
development strategy between two Southern countries rooted in a particular socialpolitical context. Viewing South-South cooperation as a "strategy" removes the need to identify or define any particular aspect of South-South relations and allows an examination of collaboration between countries on a case-by-case basis. For countries of the South, South-South cooperation offers an additional tool or strategy to enhance their economic or political interests. The lack of substantial, reliable data on what is happening in the Global South between development partners in general and between middle-income countries (MIC) and low-income countries (LIC) in particular, obscures an empirical understanding of the rationale for Southern actors' involvement in development cooperation with other less developed countries.

\section{COMPLEXITY OF SOUTH-SOUTH COOPERATION}

The complexity of South-South cooperation is rooted in the North and South's contrasting approaches to South-South cooperation. Southern actors pursue South-South cooperation in a manner that is fundamentally different from traditional Northern actors. From the perspective of the Global South, South-South cooperation is a tool to augment their development agendas. The principles of South-South cooperation-horizontality and equality, mutual benefit, non-intervention in domestic affairs, ownership, solidarity, and sovereignty - largely emanate from the historical and lived experiences of countries from the Global South. Specifically, developing countries have pursued South-South cooperation as a mechanism to redress the unequal power relations found in the international system among states following shared colonial experiences and struggles with countries of the North. Global South countries take a broad-based approach to 
cooperation that goes beyond strict bilateral exchanges between governments to encompass civil society, non-governmental organizations (NGOs), the private sector and tri-lateral forms of cooperation. Trilateral cooperation includes two or more Southern countries and a Northern country or institution with Northern financing for developing countries activities and programs. Southern actors are not limited to only the public sector; they may include private sources of funding through public-private partnerships. South-South cooperation as a model of development cooperation has options, policies, and trajectories more expansive than the North.

Unlike the South's expansive basis for South-South cooperation, the North's key measure for "official development assistance" or ODA is that which follows the Organization for Economic Co-operation and Development-Development Assistance Committee (OECD-DAC) aid based targets, assessment, and performance measures. The OECD-DAC's definition includes aid flows to officially sanctioned entities (states, territories, executive agencies) on the DAC list of ODA Recipients and to multilateral institutions. ${ }^{12}$ The aid flows must be concessional and carry a grant element of at least $25 \% .^{13}$

In practice, South-South cooperation falls outside DAC-ODA prescription and is not included. Specifically, DAC-ODA excludes development assistance involving private sector financing, which includes loans and grants that are for strictly commercial

\footnotetext{
${ }^{12}$ From the OECD webpage on Official development assistance - definition and coverage. Organization for Economic Co-operation and Development. (n.d.). Official development assistance - definition and coverage. OECD.org. Accessed July 21, 2014. http://www.oecd.org/investment/stats/officialdevelopmentassistancedefinitionandcoverage.htm.

${ }^{13}$ From the OECD Factsheet pdf "Is It ODA?" November 2008. Organization for Economic Co-operation and Development.( November 2008). Factsheet: Is it ODA?. OECD.org. Accessed July 21, 2014. http://www.oecd.org/investment/stats/34086975.pdf.
} 
purposes, export financing, and foreign direct investment. Further multilateral institutions who are engaged in South-South cooperation from the perspective of the South may not be included on the List of ODA-eligible international organizations. As a result, critical amounts of development assistance flows by major non-DAC countries of the South such as Brazil, China, India, and South Africa are not included in OECD-DAC official ODA. The lack of comprehensive data on all the forms of development assistance on the Global South misses the multifaceted nature of South-South cooperation under the South's rubric and implies that the North and South's perception of what constitutes development differ. Much of the North's approach dismisses development underway in the South, which too contributes to the complexity in defining South-South cooperation. Therefore, the DAC's ODA prescription and the non-DAC countries broad-based, nonprescriptive development serve as the basis to the contrasting approaches to South-South cooperation.

In a narrow sense, South-South cooperation is simply a form of "assistance" whether pertaining to trade, investment, technology transfers, or development (social, political, educational, etc.) as long as the partners involved are from the South. The differences between governments and institutions of the North and South's development policies coupled with the evolving, often ad hoc ${ }^{14}$ "cooperative" non-policy driven activities between and among the Global South points to further inherent complications surrounding defining South-South cooperation. ${ }^{15}$ More importantly, there is the apparent resistance of Southern donors (Brazil, China, India) to follow official definitions and

\footnotetext{
${ }^{14}$ Quadir (2013). 328.

${ }^{15}$ Bilal (2012). 20-21.
} 
prescription outlined by the North. Defining, evaluating, and assessing South-South cooperation is complex due to the contrasting approaches to development cooperation by the North and South, as well as the diversity of actors and development models within the Global South.

This study targeted South-South cooperation between Brazil and Haiti, two states that are considered to be part of the Global South. ${ }^{16}$ These states were selected for their potential to examine South-South cooperation in the area of development in a single region of the Global South, with Brazil as the development provider and Haiti the recipient country. Brazil and Haiti represent the most antithetical states and least similar development positions in Latin America and the Caribbean (LAC). Examining development cooperation between them could contribute to a better understanding of what works for meeting the challenges of development in other Middle Income CountryLeast Income Country (MIC-LIC) contexts. Further, these two case countries provide an example of the greatest potential to examine the greatest degree of mutually beneficial cooperation between the most extreme development conditions.

Brazil is a MIC with aspirations of regional and global leadership. Brazil stands out amongst the BRICS economies as a provider of development assistance to other developing countries. ${ }^{17}$ Brazil has a number of comparative advantages to draw on including its dual status as recipient and provider, technical and scientific expertise, and successful social and economic development policies and experiences including poverty

\footnotetext{
16 Önis (2016).

17 Hanson, Gordon H. (2012). "The Rise of Middle Kingdoms: Emerging Economies in Global Trade." The Journal of Economic Perspectives, 26(2): 41-63; Quadir, 2013.
} 
reduction. ${ }^{18}$ Historically, Brazil has led technical cooperation in the areas of health, agriculture and professional qualification which it perceives as a tool to strengthen its bilateral relations with other countries. ${ }^{19}$ The concept of development is embedded in its domestic and foreign policies, which provides a level of credibility as it seeks to influence the international aid architecture as a leader and champion of developing countries. Currently, Portuguese-speaking African countries (PALOPs) are the main recipients of Brazilian development assistance. ${ }^{20}$ According to the Brazilian Ministry of External Relations document "South-South Cooperation Activities Carried out by Brazil," 20 African countries receive South-South cooperation and of those cited, eight are LICs. ${ }^{21}$ Santiso (2013) found that overall Brazilian aid for international cooperation could potentially be "15 times" the Brazilian Cooperation Agency" [ABC] 30 million budget. $^{22}$ This suggests that the Brazilian government's commitment to international cooperation includes other ministries and their institutes outside the Ministry of Foreign Affairs' Brazilian Cooperation Agency. According to Costa Vaz and Inoue, the Ministries of Education, Science and Technology, and Health and Agriculture have also

\footnotetext{
${ }^{18}$ Inoue, Cristina Yumie Aoki and Costa Vaz, Alcides (2012). "Brazil as 'Southern donor': Beyond Hierarchy and National Interests in Development Cooperation?." Cambridge Review of International Affairs, 25(4): 507-534.

${ }^{19}$ Ibid.; Vieira, Marco Antonio and Alden, Chris (2011). "India, Brazil, and South Africa (ISBA): SouthSouth Cooperation and the Paradox of Regional Leadership." Global Governance, 17: 507-528.

${ }^{20}$ Inoue and Costa Vaz (2012).

${ }^{21}$ Brazilian Ministry of External Relations (July 2007). "South-South Cooperation Activities Carried Out by Brazil." Under - Secretariat General for Cooperation and Trade Promotion. Accessed October 12, 2016. http://funag.gov.br/loja/download/421-South-

South_Cooperation_Activities_Carried_Out_By_Brazil.pdf

${ }^{22}$ Santiso, Javier (2013). The Decade of the Multilatinas. Cambridge: Cambridge University Press, 232
} 
engaged in international cooperation. ${ }^{23}$ Furthermore, Brazil did not sign on to a OECD declaration on aid effectiveness until the 2011 Organisation for Economic Co-operation and Development Fourth High level Forum on Aid Effectiveness in Busan, South Korea. ${ }^{24}$ Therefore, it can be expected that Brazil's view of aid effectiveness (and accountability) will differ from traditional OECD-DAC countries. ${ }^{25}$

Brazilian engagement in development cooperation with Haiti a LICs was strategic when considering other states in LAC which are considered lower middle and middle income countries, and which are a lower priority in terms of receiving development assistance from Brazil. ${ }^{26}$ Table 1 illustrates how priority was given to Haiti over other LIC in the area of structural projects from the Brazilian Ministry of Foreign Relations between 2000 and 2014 .

Table 1

Structural Projects of the Brazilian Ministry of Foreign Relations in Latin America and the Caribbean (LAAC) and Africa 2000-2014

\begin{tabular}{|c|c|c|}
\hline Region/Country & Area & Investment in \$US \\
\hline \multicolumn{3}{|l|}{ LAAC Countries } \\
\hline Jamaica & Education & $3,717,700,00$ \\
\hline Paraguay & Education & $1,204,389.39$ \\
\hline \multicolumn{3}{|c|}{$\begin{array}{l}{ }^{23} \text { Costa Vaz, Alcides and Inoue, Cristina Yumie Aoki (2007). "Emerging Donors in International } \\
\text { Development Assistance: The Brazil Case," Ottawa: International Development Research Centre } \\
\text { Partnership and Business Development Division. }\end{array}$} \\
\hline \multicolumn{3}{|c|}{${ }^{24}$ de Renzio and Seifert (2014). } \\
\hline \multicolumn{3}{|l|}{${ }^{25}$ Quadir (2013). } \\
\hline
\end{tabular}




$\begin{array}{lll}\text { Bolivia } & \text { Professional Formation } & 3,758,136.00 \\ \text { Colombia } & \text { Professional Formation } & 1,334,233.00 \\ \text { Guatemala } & \text { Professional Formation } & 2,760,764.17 \\ \text { Haiti } & \text { Professional Formation } & 11,178,977.00 \\ \text { Haiti } & \text { Health } & 10,725,116.00 \\ \text { Haiti } & \text { Agriculture } & 6,084,140.00 \\ \text { Total } & & 37,045,755.56 \\ \text { African Countries } & \text { Health } & 4,500,000.00 \\ \text { Ghana } & \text { Education } & 2,970,681.60 \\ \text { Guinea-Bissau } & \text { Health } & 754.530 .00 \\ \text { Mozambique } & \text { Education } & 3,636,092.00 \\ \text { Mozambique } & \text { Urban Development } & 1,236,006.00 \\ \text { Mozambique } & \text { Education } & 488,797.00 \\ \text { Mozambique } & \text { Social Security } & 615,475.00 \\ \text { Mozambique } & \text { Education } & 4,073,428.00 \\ \text { São Tomé and Príncipe } & \text { Social Development } & 1,250,393.83 \\ \text { São Tomé and Príncipe } & \text { Agriculture } & 1,889,378.00 \\ \text { Senegal } & & 20,660,251.43 \\ \text { Total } & & \end{array}$

Source: Brazilian Ministry of External Relations (2012). Webpage. "Projetos Estruturantes."

At USD $\$ 27,988,233$, Haiti received over $75 \%$ of Brazil's investment in structural projects in LAAC and more than the entire African region at USD\$20,660,251.43 between 2000 and 2014. Brazil's active interest in the interplay between security and development interventions characterizes the Brazil-Haiti framework of engagement. In 2004, Brazil joined Argentina, Canada, Chile, France, and the U.S. in forming the "Haiti core group," which intervened following the overthrow of President Jean-Bertrand Aristide. Brazil extended its efforts in the same year with the management of the UN Stabilization Mission in Haiti (MINUSTAH) peacekeeping mission. ${ }^{27}$ Starting in 2004, Brazil became the leader of MINUSTAH and played an important role in helping Haiti after the 2010 earthquake. ${ }^{28}$ In addition to its security interventions, Brazil had 31

\footnotetext{
${ }^{27}$ Vieira and Alden (2011).

${ }^{28}$ Ibid.
} 
bilateral projects in agriculture, health and education predating the 2010 earthquake. ${ }^{29}$ Brazil's presence in Haiti connected the role of security and development as a precursor to the country's state-building and development efforts. In the past 10 years, Haiti has been one of Brazil's two largest recipients of humanitarian assistance; Somalia (USD \$27 million) and Haiti (USD\$24 million). ${ }^{30}$

President Luiz Inácio "Lula” da Silva (Lula) declared Haiti one of eight priority recipients of bilateral horizontal cooperation by The Brazilian Cooperation Agency $(\mathrm{ABC})$, responsible for international technical cooperation. ${ }^{31}$ This follows from Brazil's focus on Southern relations and development cooperation, with other developing countries as a cornerstone of its foreign policy. Nieto offered five reasons for Brazilian involvement in peacekeeping operations that by extension Haiti as a recipient partner for development cooperation. The reasons include: (a) the International Good Samaritan Syndrome, where Brazil's sense of duty motivates their participation; (b) National Interests-Driven Strategic Actor, representing an opportunity for Brazil solidify its chances to gain a permanent seat on the UN Security Council and strategy to increase its international standing; (c) monetary compensation from the UN, which provides the least compelling reason as the compensation provided for troop deployment does not cover the total costs to keep forces in Haiti; (d) live-combat training, which offers Brazilian combat

\footnotetext{
${ }^{29}$ Nieto, W. Alejandro Sánchez (2012). "Brazil's Grand Design for Combining Global South Solidarity and National Interests: A Discussion of Peacekeeping Operations in Haiti and Timor." Globalizations, 9(1): 173 .

${ }^{30}$ Global Humanitarian Assistance (2015). Global Humanitarian Assistance Report 2015. Bristol: Global Humanitarian Assistance. Accessed December 16, 2016. http://www.globalhumanitarianassistance.org/wpcontent/uploads/2015/06/GHA-Report-2015_-Interactive_Online.pdf

${ }^{31}$ Inoue and Costa (2012).
} 
troops with the opportunity train for real-life combat operations that it would otherwise have limited experience; and (e) national pride, which can be derived from successes gained around MINUSTAH operations, particularly its efforts in Cite' Soleil. ${ }^{32}$

Haiti is the only LIC and Least Developed Country (LDC) in the Western Hemisphere $^{33}$ and located in one of Brazil's priority regions. Historically, Haiti has faced severe external impediments to full inclusion (diplomatic and economic) into what is considered the Westphalian international system of nation-states. Also, there was the paradox of a formally enslaved colony seeking trade and commerce with slave-holding states resistant to a Black republic and the Haitian president Pétion suggesting the payment of an indemnity to France in 1814. Haiti's relations with the Global North has since its inception contributed to its precarious domestic situation including arrested development, political correction, and military intervention by those same countries. ${ }^{34}$ Historically, Haiti's international context and affairs have contributed to its ongoing development dilemma and subsequent efforts. ${ }^{35}$ Today, the Caribbean island has approximately $10,485,800$ inhabitants $^{36}$ and is ranked number 10 on Foreign Policy

\footnotetext{
${ }^{32}$ Nieto (2012) 166-69.

${ }^{33}$ World Bank (2017). "Haiti Overview.” (webpage). Accessed February 27, 2017. http://www.worldbank.org/en/country/haiti/overview\#1.

${ }^{34}$ O'Connor, Daniel, Brisson-Boivin, Kara and Ilcan, Suzan (2014). "Governing Failure: Development, Aid and Audit in Haiti." Conflict, Security \& Development, 14(3): 309-330; Ramachandran, Vijaya and Walz, Julie (2015). "Haiti: Where Has all the Money Gone?" Journal of Haitian Studies, 21(1): 26-65.

${ }^{35}$ O’Connor et al. (2014).

${ }^{36}$ Central Intelligence Agency (2016). Haiti. In The World Factbook. Accessed February 15, 2017. https://www.cia.gov/library/publications/the-world-factbook/geos/ha.html.
} 
Magazine failed states ranking for $2015,{ }^{37}$ despite a combined USD\$17.3 billion aid pledged for humanitarian and debt relief, recovery efforts and private charitable contributions and 6.4 billion disbursed between 2010 and 2013 following the 2010 earthquake. ${ }^{38}$ Haiti remains one of 31 LICs in the world, despite the number of bilateral and multilateral efforts to improve its development position.

Napoleão and Kalil (2015) cited Waisbich and Pomeroy's reference to Haiti as Brazil's "laboratory of multi-sector engagement" to achieve greater influence as well as an "end in itself." 39 Haiti represented a test case by which Brazil could justifiably extend its influence on an international stage. Each of Nieto's reasons for Brazil's engagement in peacekeeping could be applied to Haiti.

Due to the complexity of South-South cooperation and its shifting development trajectories and relationships engender different types of analysis, one that occurs with the inclusion and governing auspices of the North, another between the emerging powers and that which occurs between emerging powers or MICs and LICs. In the current study, I selected the latter as its focus. The ideas and possibilities inherent in development cooperation between MICs and LICs suggest that the Global South has development potential heretofore not available for countries of the South. For LICs, the burgeoning number of actors engaging in what the South considers development and development

\footnotetext{
${ }^{37}$ Foreign Policy Magazine (2016). "Fragile State Index." (webpage). Accessed December 27, 2016. http://foreignpolicy.com/fragile-states-index-2016-brexit-syria-refugee-europe-anti-migrant-boko-haram/.

${ }^{38}$ Civic Impulse (2016). S. 1104 - 113th Congress: Assessing Progress in Haiti Act of 2014. Accessed December 15, 2016. https://www.govtrack.us/congress/bills/113/s1104.

${ }^{39}$ Napoleão, Thomaz and Kalil, Mariana (2015). "Stabilization as the Security of Peacebuilding? The Experience of Brazil and MINUSTAH in Haiti." Brasiliana Journal for Brazilian Studies, 3(2). Accessed on December 27, 2017. http://ojs.statsbiblioteket.dk/index.php/bras/article/view/19998/18191.
} 
related projects and activities are positioned to gain or lose the most in terms of the quality and quantity of transactions for their engagement with MICs.

\section{KEY MILESTONES AND EVENTS IN SOUTH-SOUTH COOPERATION}

For countries of the Global South, South-South cooperation follows two main lines of thinking, the need for political cooperation and the need for economic and technological cooperation. ${ }^{40}$ According to Ugwuja et al., the reason for South-South cooperation is the "seemingly intractable asymmetry" between the North and the South. ${ }^{41}$ The context that surrounds the central question follows from the Global South's response to the larger socio-political and economic realities developing countries found themselves within the international system, vis-à-vis the Global North, leading up to and following the Cold War.

Specifically, Cold War geopolitics, foreign policy, and political economy during that era led to the South's organizing around the need for political cooperation and economic and technical cooperation. ${ }^{42}$ Without the requisite level of development, the South could not affect the economic changes necessary to compete and level the playing field with the developed economies of the world. Therefore, South-South cooperation in terms of trade and economic cooperation "represented a more political aspiration than an economic reality." 43

\footnotetext{
${ }^{40}$ IBON International (2014).

${ }^{41}$ Ugwuja, et. al (2014), 174.

${ }^{42}$ IBON International (2014).

43 United Nations (2011), 3.
} 
This situation was further buttressed by the need to counteract the influence of Cold War politics and military tensions between Western bloc (United States and its allies comprised of the North Atlantic Treaty Organization or NATO countries and Japan) Eastern bloc (Union of Soviet Socialist Republics or Soviet Union and its allies among the Warsaw pact countries). Many areas of the developing world served as the backdrop for Cold War political and military tensions. The threat of war was poignant with the events surrounding the Bay of Pigs Invasion and the subsequent Cuban Missile Crisis. Further, the United States used foreign aid under the guise of "mutual security" as a Cold War strategy to influence countries such as South Korea, Taiwan, Vietnam, the Philippines, Thailand, India, Iran, Jordan and Pakistan in its foreign policy of containment of the spread of communism by the Soviet Union. ${ }^{44}$ Table 2 highlights key milestones and events in South-South cooperation during the Cold War era among countries and regions of the South.

Table 2

Key Milestones and Events in South-South Cooperation among Regions and States of the South during the Cold War Era

\begin{tabular}{|c|c|c|}
\hline $\begin{array}{l}\text { Aspect of South-South } \\
\text { Cooperation }\end{array}$ & $\begin{array}{l}\text { Trans-regional Conferences, } \\
\text { Meetings \& Agreements between } \\
\text { Southern States }\end{array}$ & Outcome(s) \\
\hline $\begin{array}{l}\text { Economic \& } \\
\text { Technological }\end{array}$ & The Arab League (1945) & $\begin{array}{l}\text { Arab League Educational, Cultural } \\
\text { and Scientific Organization } \\
\text { (ALESCO) (1964) (Clements, 2001) }\end{array}$ \\
\hline Political & $\begin{array}{l}\text { The Asian-African Conference or } \\
\text { Bandung Conference in Bandung, } \\
\text { Indonesia (1955) }\end{array}$ & $\begin{array}{l}\text { New Asian-African Strategic } \\
\text { Partnership (NAASP) (2005) }\end{array}$ \\
\hline Political & $\begin{array}{l}\text { Afro-Asian People's Solidarity } \\
\text { Conference; Cairo, Egypt (1957) }\end{array}$ & $\begin{array}{l}\text { Afro-Asian People's Solidarity } \\
\text { Organization (1960) }\end{array}$ \\
\hline
\end{tabular}


Economic \&

Technological

The Latin America Free Trade Area

(LAFTA) (1960)

\section{Political}

Preparatory meeting for the First NAM Summit Conference; Cairo (1961) (Trivedi, 2005)

Political

\section{Economic \&}

Technological

\section{Political}

Political

Economic and

Technological
Conference on Problems of Developing Countries; Cairo, Egypt (1962) (IBON International, 2014)

Organization of African Unity (OAU), Addis Ababa, Ethiopia (1963) (Secretariat Organization of African Unity, 1963)

The South Commission (1987) is an intergovernmental body of developing countries with observer status at the UN. $9^{\text {th }}$ NAM Summit; Belgrade, Yugoslavia (1989)
The Latin American Integration Association (ALADI) (1980) (1980 Treaty of Montevideo; Adopted by the LAFTA Council of Foreign Affairs, 1980)

The First Conference of Heads of State or Government of NonAligned Countries or the Belgrade Summit in Belgrade, Yugoslavia (1961)

The Non-Aligned Movement (NAM) with subsequent summits until the XVII NAM Summit Conference of the Heads of State at Algiers, Algeria in 2014 (Ministry of Foreign Affairs of Algeria, 2014)

The Cartagena Document on Methodology adopted at the XI NAM Summit Conference of the Heads of State; Cartagena, Colombia, 1995 (The Non-Aligned Movement, 2001)

Promoted South-South cooperation for human development and international solidarity at the XIV NAM Summit of the Heads of State; Havana, Cuba, 2006 (IBON International, 2014)

Group of Seventy Seven (G77) and UNCTAD in 1964 (United Nations Conference on Trade and Development, 2013)

African Union (2002) (African Union, 2014)

Was replaced by with the South Centre (1995) (INSouth, 20082014).

The G-15 is created

Source: Partners in Population Development (n.d.). "Chapter 1, South-South Cooperation: A Pathway for Development." Development except where indicated.

\section{The Need for Political Cooperation}

The Asian-African Conference or Bandung Conference (1955) is one of two key trans-regional conferences of the leaders of the developing world in response to the 
socio-political realities of the Cold War. This conference is commonly cited by writers as the starting point for South-South cooperation ${ }^{45}$ and represents the South's entrance into international affairs. The conference was attended by 20 , mostly newly independent countries from the continents of Asia and Africa under the leadership of Prime Minister Nehru with Prime Ministers Soekarno and Nasser to promote economic, political, and cultural cooperation between the regions of Africa and Asia, as well as to promote world peace.

Many of the scholars writing about South-South cooperation have cited the importance of solidarity among developing countries and Global South as an aspect of South-South cooperation. ${ }^{46}$ As a representative body of developing countries, attendees contributed to an understanding of a solidarity based on a shared historical reality (colonialism and dependency) in addition to commonalities around their regions, cultures, and religions. This new reality reinforced a burgeoning awareness of regions whose identity were considered underdeveloped or developing within the international system. After this conference, references to solidarity were attributed to developing countries' efforts to affect change in international affairs as well as a recognition of their efforts to improve their social, political, and economic prospects.

The conference resulted in the adoption of the "Principles of Bandung." A summary of the 10 principles espoused at the conference are listed in the Table 3 below.

\footnotetext{
${ }^{45}$ IBON International (2014); Rosseel, Peter, De Corte, Erik, Blommaert, Jan and Verniers, Elke (2009). "Approaches to North-South, South-South and North-South-South Collaboration: A Policy Document." Ku Leuven. Accessed November 26, 2014. https://lirias.kuleuven.be/handle/123456789/229636.

46 IBON International (2014); Roy, Rathin, and Andrade, Melissa (2010). "South-South Cooperation? The Same Old Game or a New Paradigm?.” Poverty in Focus. International Policy Centre for Inclusive Growth, Bureau for Development Policy, UNDP, 25.
} 
Table 3

The Ten Principles of the Bandung Conference, 1955

\begin{tabular}{|c|c|}
\hline \multicolumn{2}{|c|}{ The Ten Principles of Bandung, 1955} \\
\hline 1. Human rights & $\begin{array}{l}\text { 6. "[A]bstention from the use of arrangements of } \\
\text { collective defense to serve the particular interests } \\
\text { of any of the big powers" and "[a]bstention by any } \\
\text { country from exerting pressures on other } \\
\text { countries." (non-alignment) }\end{array}$ \\
\hline $\begin{array}{l}\text { 2. Sovereignty and territorial integrity of all } \\
\text { nations }\end{array}$ & 7. Non-aggression \\
\hline 3. Equality (races of people, large and small states) & $\begin{array}{l}\text { 8. The peaceful settlement of international dispute } \\
\text { per the Charter of the United Nations }\end{array}$ \\
\hline $\begin{array}{l}\text { 4. Non-intervention and non-interference in } \\
\text { internal affairs }\end{array}$ & $\begin{array}{l}\text { 9. "Promotion of mutual interests and co- } \\
\text { operation" }\end{array}$ \\
\hline $\begin{array}{l}\text { 5. Right to single or collective defense of each } \\
\text { country per the Charter of the United Nations }\end{array}$ & 10. Justice and international obligations \\
\hline
\end{tabular}

Source: Final Communiqué of the Asian-African Conference of Bandung (24 April 1955).

These principles have served as a working template for South-South mandates, initiatives, and perspectives for countries in the Global South such as the emphasis on sovereignty, non-interference, and non-alignment. Further, the Principles have set the tone for political self-determination among developing countries and served as a template for succeeding iterations of South-South cooperation principles and platforms in SouthSouth and North-South dialogue.

In the broadest sense, the conference reflected the depth of the problems the South occasioned upon becoming independent states during the Cold War, as well as those the South continue to face in the post-Cold War era as countries seek help and assistance among themselves. This conference serves as an early indicator of how the South viewed itself and its role in the international system. As the first inter-regional conference between developing states, the conference signaled the importance developing countries 
placed on acting jointly on common issues. Along with recognizing the importance of working together cooperatively as developing states, the South also established a precedence of adopting positions, principles and recommendations calling for actions to be governed within or in support of the United Nations (UN) and its declaration of programs.

Common negotiating positions within the United Nations system were referenced, including the call for bilateral and multilateral arrangements that stabilize the international prices and demand for primary commodities through the United Nations Permanent Advisory Commission on International Commodity Trade, the support of the United Nations Universal Declaration of Human Rights as the standard for human rights, and the support of the Arab people in Palestine in accordance with the United Nations Resolutions on Palestine per the UN Charter's principle of self-determination of all people. The Conference also regarded the United Nations as essential for the establishment and maintenance of world peace. Specifically, the Bandung Conference called for universality in the make-up of the UN body by admitting all qualified states into the UN and greater equality of representation on the UN Security Council. ${ }^{47}$ The issue of fair and adequate representation on the UN Security Council would continue as a political quagmire into the post-Cold War era, including the politics surrounding the G-4 countries which includes Brazil and India's quest for reform and a bid for permanent seats on the Council. Though the countries representing the Bandung Conference were

\footnotetext{
${ }^{47}$ Final Communiqué of the Asian-African Conference of Bandung (24 April 1955). (n.d.). Centre Virtuel de la Connaissance sur l'Europe (CVCE). Accessed October 14, 2014.

http://www.cvce.eu/en/obj/final_communique_of_the_asian_african_conference_of_bandung_24_april_19 55-en-676237bd-72f7-471f-949a-88b6ae513585.html.
} 
discussing the need for Council reform in 1955, the UN Security Council itself did not begin formal debates on reform until 1993.

The Bandung Conference represented the end of one era and the beginning of another in the developing world when for the first time, leaders from developing countries of Asia and Africa outside the auspices of the United Nations spoke out unequivocally against colonialism and racism and supported liberation from Western colonial powers. Overall, the Bandung Conference signified the voice of the Third World and developing countries in general. According to UNCTAD (2010), the Bandung Conference "provided inspiration and impetus for the development of various SouthSouth alliances in the 1960s and 1970s." ${ }^{48}$ Tan and Acharya (2008) identified three normative outcomes for the Conference: (a) a code of conduct in international relations, (b) compromise and consensus-building on questions of alignment with rival power blocs, and (c) informal and consensus-based diplomacy. ${ }^{49}$

The second pivotal trans-regional conference was the First Summit Conference (1961) which finds its origins in the Bandung Conference. ${ }^{50}$ The First Summit Conference of 1961 provided a forum to discuss and promote a view of international relations from the perspective of states who were not aligned with the either the Eastern

\footnotetext{
${ }^{48}$ United Nations Conference on Trade and Development (UNCTAD) (2010). "Economic Development in Africa Report 2010: South-South Cooperation - Africa and the New Forms of Development Partnership." United Nations Publication.7. Accessed November 16, 2016. http://unctad.org/en/Pages/Publications/EconomicDevelopmentinAfricaseries.aspx.

49 Tan, See Seng and Acharya, Amitav (2008). Bandung Revisited: The Legacy of the 1955 Asian-African Conference for International Order. Singapore: NUS Press, National University of Singapore.

50 Trivedi, Sonu. (2005). Handbook of International Organizations. New Delhi: Atlantic Publishers and Distributors.
} 
or Western blocs at the height the Cold War and the creation of the Non-Aligned Movement or NAM. NAM adopted the Principles of Bandung as its goals and objectives in its policy of non-alignment and criterion for membership. ${ }^{51}$ The criteria for membership in the movement as well as an invitation to the Summit were established at a preparatory conference in Cairo, Egypt prior to the Summit.

The criteria for membership in NAM included:

1. The country should have adopted an independent policy based on the coexistence of States with different political systems and non-alignment or should be showing a trend in favor of such a policy;

2. The country concerned should be consistently supporting the Movements or National Independence;

3. The country should not be a member of a multilateral military alliance concluded in the context of Great Power conflicts;

4. If a country has a bilateral military agreement with a Great Power, or is a member of a regional defence pact, the agreement or pact should not be one deliberately concluded in the context of Great Power conflicts;

5. If it has conceded military bases to a Foreign Power, the concession should not have been made in the context of Great Power conflicts. ${ }^{52}$

\footnotetext{
${ }^{51}$ Ministry of External Affairs; Government of India (2012). "History and Evolution of Non-Aligned Movement." Accessed October 20, 2014. https://mea.gov.in/in-focusarticle.htm?20349/History+and+Evolution+of+NonAligned+Movement.

52 The Non-Aligned Movement (NAM). "Background- The Non-Aligned Movement: Description and History." (webpage). Accessed October 20, 2014. http://www.nam.gov.za/background/history.htm.
} 
Twenty-five countries met the criteria and attended the Summit including: Afghanistan, Algeria, Burma, Cambodia, Ceylon, Congo, Cuba, Cyprus, Ethiopia, Ghana, Guinea, India, Indonesia, Iraq, Lebanon, Mali, Morocco, Nepal, Saudi Arabia, Somalia, Sudan, Tunisia, United Arab Republic, Yemen, and Yugoslavia, with Bolivia, Brazil, and Ecuador as observers. ${ }^{53}$ Yugoslavia under President Josip Broz Tito was only one of two European states represented at the conference; however, President Tito is credited along with Nehru (India), Sukarno (Indonesia), Nkruma (Ghana), and Nasser (Egypt) as the originating leaders of NAM. ${ }^{54}$

The First Summit Conference of 1961 provided a forum to discuss and promote a view of international relations from the perspective of non-aligned states. The Conference called for democratization of international relations, including fair representation within the UN system including reform of the UN Security Council to reflect the growing UN membership body as well as economic redress for the asymmetries stemming from colonialism and imperialism. ${ }^{55}$ Further, the Conference advocated for legitimacy of the $\mathrm{PRC}^{56}$ as the one representative of China and noninterference in the affairs of Cuba. ${ }^{57}$ The politics of colonialization, imperialism, and the

\footnotetext{
${ }^{53}$ Belgrade Declaration of Non-Aligned Countries, 1961 (Excerpts) (n.d.). 6. Accessed October 20, 2015. http://pustakahpi.kemlu.go.id/dir_dok/01st\%20Summit\%20of\%20the\%20Non-

Aligned\%20Movement\%20-\%20Final\%20Document\%20(Belgrade_Declaration).pdf.

${ }^{54}$ Ghosh, Peu (2013). International Relations. Delhi: PHI Learning PVT. LTD. 164.

${ }^{55}$ Belgrade Declaration of Non-Aligned Countries, 1961 (Excerpts), 9.

${ }^{56}$ Ibid. 10.

${ }^{57}$ Ibid. 8.
} 
Cold War feature prominently in the identity formation of the NAM, as it sought to address leading issues of the era.

The NAM movement was centered on summitry work among non-aligned members with subsequent advocacy on behalf of non-aligned countries. The NAM believed the best way to accomplish its objectives with such a broad, diverse group of states with different political ideologies would be to continue as a movement with "no charter, no permanent secretariat or headquarters, or, for that matter, a permanent website." 58 This anti-formality stance to institutionalization would take root and grow into a defining characteristic of South-South cooperation with the North's call for greater formality in information gathering, data, analysis and evaluation of South-South activities, whereas the Global South and its institutions continue to reserve the right to proceed with a degree of informality and flexibility. The NAM squarely placed the bulk of world problems on the U.S. and Soviet management as the two leading Great Powers in the bi-polar world, particularly in the area of world peace.

Kwame Nkrumah, the first president of Ghana and one of the fathers of the NonAligned Movement, extended the concept of non-alignment to embrace non-alignment as a revolutionary force in world affairs. Table 4 illustrates the progression in Nkrumah's rhetoric of non-alignment with quotes from Nkruma found in Das Gupta and Shahid (1981) article, “Ghana’s Non-Alignment Under Kwame Nkrumah.” 59

\footnotetext{
${ }^{58}$ Potter, William and Mukhatzhanova, Gaukhar (2012). Nuclear Politics and the Non-Aligned Movement: Principles vs Pragmatism. Milton Park, Abingdon, Oxon: Routledge for the International Institute for Strategic Studies, 23.

${ }^{59}$ Das Gupta, Anirudha and Shahid, A. S. (1981). Ghana's non-alignment under Kwame Nkruhma. International Studies, 401 and 407.
} 
Table 4

\section{A Brief Compilation of Kwame Nkrumah's Perspectives on of Non-alignment between 1958 and 1973}

\begin{tabular}{|c|c|c|}
\hline Year & Perspective & Quote \\
\hline 1958 & $\begin{array}{l}\text { Political } \\
\text { strategy }\end{array}$ & $\begin{array}{l}\text { This policy of non-alignment we have interpreted to imply that the } \\
\text { Government would act as it sees best on any issue in the light of the country's } \\
\text { obligations to the UN Charter, our position in relation to the African continent } \\
\text { and the Commonwealth, our adherence to the principles enunciated at the } \\
\text { Bandung and Accra conferences, and our determination to safeguard our } \\
\text { independence and sovereignty. Ghana Today (Accra), September 17, } 1958\end{array}$ \\
\hline 1960 & $\begin{array}{l}\text { Third World } \\
\text { organizing } \\
\text { tool }\end{array}$ & $\begin{array}{l}\text { I will even be bold to offer the proposal that all uncommitted non nuclear } \\
\text { countries of the world, particularly of Africa and Asia, should summon } \\
\text { themselves into a conference with a view to forming a non-nuclear third } \\
\text { force---a war-preventing force between the two blocs of the so-called East and } \\
\text { West. Kwame Nkrumah Address to Parliament, July } 1960\end{array}$ \\
\hline 1968 & $\begin{array}{l}\text { Alignment } \\
\text { with } \\
\text { Socialism }\end{array}$ & $\begin{array}{l}\text { The world struggle, and the cause of world tension, has to be seen not in the } \\
\text { old political context of the Cold War, that is, of nation states and Power blocs, } \\
\text { revolutionary and counter-revolutionary peoples.... If we are to achieve } \\
\text { revolutionary Socialism, then we must avoid any suggestion that will imply } \\
\text { that there is any separation between the Socialist world and a "Third World". } \\
\text { Labour Monthly (London), October } 1968\end{array}$ \\
\hline $\begin{array}{l}\text { n.d. } \\
\text { given }\end{array}$ & $\begin{array}{l}\text { A call to } \\
\text { action }\end{array}$ & $\begin{array}{l}\text { Old beliefs die hard. Although non-alignment is an anachronism, there are } \\
\text { still a few politicians and heads of state who cling to the idea of neutralism } \\
\text { and who advocate holding of more conferences of non-aligned states. Their } \\
\text { thinking a form of political escapism - a reluctance to face the realities the } \\
\text { present situation (Kwame Nkrumah as cited in Das Gupta and Shahid, 1981, } \\
\text { 402) }\end{array}$ \\
\hline 1973 & $\begin{array}{l}\text { Basis for } \\
\text { policy }\end{array}$ & $\begin{array}{l}\text { We are all here as non-aligned nations, but the term 'non-aligned' as applied } \\
\text { to us has not yet covered every form of policy which it connotes. We came } \\
\text { into existence as a protest and a revolt against the state of affairs in } \\
\text { international relations caused by the division of the world into opposing blocs } \\
\text { of East and West. We came into existence as a revolt against imperialism and } \\
\text { neo-colonialism, which are also the basic cause of world tension and } \\
\text { insecurity. Kwame Nkrumah in Revolutionary Path, } 1973\end{array}$ \\
\hline
\end{tabular}

Source: Das Gupta, Anirudha and Shahid, A. S. (1981). "Ghana's Non-alignment under Kwame Nkruhma." International Studies, 20(1-2): 401 and 407.

Nkrumah's remarks reflect an evolution in this thinking. Nkrumah found that the Cold

War and subsequent neo-colonialism did not improve the relative position of non-aligned countries vis-à-vis the Great Powers (former colonizers). His view of non-alignment 
went from moderate (conferencing) to more revolutionary policy proposals (Socialism). Nkrumah's view of non-alignment transformed beyond rhetoric to the idea of a socialpolitical project and policy.

In conclusion, the need for political cooperation by the Global South during the Cold War era presented recurring themes around colonialism/decolonialization, imperialism/neo-colonialism, disarmament, as well as democratization of international relations and global governance structures. The ideas and concepts emanating from the Bandung Conference would inspire the Non-aligned Movement which would in term influence and mark the political rhetoric of the Global South. As the need for political cooperation did not negate the inclusion of the North, the need for economic and technological cooperation also included a role and place for developed countries and Northern institutions.

\section{The Need for Economic and Technical Cooperation}

South-South economic and technical cooperation has been a joint effort between the South and the North. The South has a long history of organizing as a bloc within the UN System and pushing for changes to close the economic and technological divide between the North and the South. Table 5 highlights the key milestones and events in South-South cooperation through North-South dialogue and discussions during the Cold War era. 
Table 5

Key Milestones and Events in South-South Cooperation during the Cold War Era within the United Nations System

\begin{tabular}{|c|c|c|}
\hline $\begin{array}{l}\text { Aspect of South- } \\
\text { South Cooperation }\end{array}$ & $\begin{array}{l}\text { Trans-regional conferences, } \\
\text { meetings, and agreements on } \\
\text { behalf of the South }\end{array}$ & Outcome(s) \\
\hline $\begin{array}{l}\text { Economic \& } \\
\text { Technological }\end{array}$ & $\begin{array}{l}\text { The United Nations Expanded } \\
\text { Programme of Technical } \\
\text { Assistance (EPTA) (1949) }\end{array}$ & $\begin{array}{l}\text { Adopted by the ECOSOC in 1949) and "taken } \\
\text { up in a Resolution of the United Nations } \\
\text { General Assembly" in } 1949 \text { (United Nations } \\
\text { Education Educational, Scientific and Cultural } \\
\text { Organization (UNESCO)) }\end{array}$ \\
\hline $\begin{array}{l}\text { Economic \& } \\
\text { Technological }\end{array}$ & $\begin{array}{l}\text { The United Nations Special } \\
\text { Fund (UNSF) (1958) }\end{array}$ & $\begin{array}{l}\text { Merged with the EPTA creating the United } \\
\text { Nations Development Programme (UNDP) in } \\
\text { 1965. (Auerbach and Yonekawa) }\end{array}$ \\
\hline $\begin{array}{l}\text { Economic \& } \\
\text { Technological }\end{array}$ & $\begin{array}{l}\text { The Group of at the first the } \\
\text { United Nations Conference on } \\
\text { Trade and Development (1964) }\end{array}$ & $\begin{array}{l}\text { The Charter of Algiers (1967) (First } \\
\text { Ministerial Meeting of the Group of 77); the } \\
\text { New International Economic Order (NIEO) } \\
\text { (1967) }\end{array}$ \\
\hline $\begin{array}{l}\text { Economic \& } \\
\text { Technological } \\
\text { Economic \& } \\
\text { Technological }\end{array}$ & $\begin{array}{l}\text { United Nations Development } \\
\text { Programme (1965) } \\
\text { UN Working Group for } \\
\text { Technical Cooperation among } \\
\text { Developing Countries (TCDC) } \\
\text { (1972), (United Nations Office } \\
\text { for South-South Cooperation) }\end{array}$ & $\begin{array}{l}\text { United Nations Capital Development Fund } \\
\text { (UNCDF) in } 1966 \text { (United Nations). } \\
\text { Recommended the creation of a special unit for } \\
\text { TCDC within the UN system }\end{array}$ \\
\hline $\begin{array}{l}\text { Economic \& } \\
\text { Technological }\end{array}$ & $\begin{array}{l}\text { The UN General Assembly } \\
\text { endorses the establishment of a } \\
\text { special unit within the United } \\
\text { Nations Development } \\
\text { Programme to promote TCDC } \\
\text { (United Nations) }\end{array}$ & $\begin{array}{l}\text { United Nations Office for South-South } \\
\text { Cooperation that manages the UN Fund for } \\
\text { South-South Cooperation and the PGTF } \\
\text { (United Nations Office for South-South } \\
\text { Cooperation) }\end{array}$ \\
\hline $\begin{array}{l}\text { Economic \& } \\
\text { Technological }\end{array}$ & $\begin{array}{l}\text { The UN Conference on } \\
\text { Technical Cooperation among } \\
\text { Developing Countries; Buenos } \\
\text { Aires, Argentina (1978) }\end{array}$ & $\begin{array}{l}\text { Buenos Aires Plan of Action (BAPA) (1978); } \\
\text { the Special Unit for TCDC strengthened to } \\
\text { promote, coordinate and support South-South } \\
\text { and triangular cooperation globally within and } \\
\text { outside the UN } \\
\text { (http://ssc.undp.org/content/ssc/about/faq.html) }\end{array}$ \\
\hline $\begin{array}{l}\text { Economic \& } \\
\text { Technological }\end{array}$ & $\begin{array}{l}\text { High-level Conference of the G- } \\
\text { 77; Caracas, Venezuela (1981) }\end{array}$ & $\begin{array}{l}\text { Caracas Programme of Action on Economic } \\
\text { Cooperation among Developing Countries } \\
\text { (1981) }\end{array}$ \\
\hline $\begin{array}{l}\text { Economic \& } \\
\text { Technological }\end{array}$ & $\begin{array}{l}\text { The Perez Guerrero Trust Fund } \\
\text { for Economic and Technical } \\
\text { Cooperation among Developing } \\
\text { Countries (PGTF) (1981) }\end{array}$ & \\
\hline $\begin{array}{l}\text { Economic \& } \\
\text { Technological }\end{array}$ & $\begin{array}{l}\text { Ministerial Meetings of the } \\
\text { Group of 77; Belgrade, } \\
\text { Yugoslavia (1988) }\end{array}$ & $\begin{array}{l}\text { Ratified the Agreement on a Global System of } \\
\text { Trade Preferences among Developing } \\
\text { Countries (GSTP) (1989) }\end{array}$ \\
\hline
\end{tabular}


Though countries in the Global South met and organized outside of the established system of governance such as the UN, they would take their united efforts of solidarity to push for changes within and not against these institutions. This trend would continue after the end of the Cold War with the creation of new, wholly South-South entities such as the BRICS and India-Brazil-South Africa Dialogue (IBSA).

\section{$\underline{\text { The North and Northern Institutions }}$}

From the perspective of the developed countries of the North, cooperation between countries was not initially conceived of as North-South cooperation or the fostering of South-South cooperation, but that of directly supporting other European countries and allies. Events that took place prior to and during the Cold War contributed to the creation of the international aid architecture and development cooperation between Northern donors and Southern recipients. Northern aid influenced politics leading to and surrounding the Cold War.

\section{The United States}

In 1896, the United States used food surpluses to "alleviate suffering" abroad and "open future markets" for U.S. farmers. ${ }^{60}$ Food shortages in Europe led the United States to pass the U.S. Lend-Lease Act of 1941, creating the U.S. Food for Freedom Program. The Act extended the right to "sell, transfer title to, exchange, lease, lend, or otherwise dispose of, to any such government [whose defense the President deems vital to the

\footnotetext{
${ }^{60}$ Van Bilzen, Gerard (2015). The Develpoment of Aid. Newcastle upon Tyne, UK: Cambridge Scholars Publishing, 53.
} 
defense of the United States] any defense article."61 The program transferred food and supplies to allied countries (United Kingdom, Belgium, Norway, Poland, and China) considered Allies between 1941 and 1945 and considered key in winning the Second World War. The program benefited the United States by increasing its overall food production and capacity levels.

\section{Britain}

During the 1920s, Britain provided oversees assistance in the areas of technical assistance and scholarships for their colonies. Their focus shifted to agriculture and industry with the Colonial Development Act of 1929. The Act earmarked regular funding for the development of colonies for the first time. The British Colonial and Welfare Act of 1940 sought the promotion of development which included conditions for assistance and cancellation of debts. One conditionality placed on colonial governments was that their proposals for assistance also support of the European war effort. A limited number of colonial governments chose to submit proposals until the end of the war was approaching. The British Colonial and Welfare Act of 1945 increased funding and extended assistance to the colonies until 1964. Rather than discontinue funding, the Commonwealth Development Act of 1963 was passed and introduced the possibility of soft loans.

\footnotetext{
${ }^{61}$ Shurtleff, William and Aoyagi, Akiko (2015). History of Soybeans and Soy Foods in Eastern Europe (Including All of Russia) (1783-2015). Soy Center, 503.
} 


\section{Creation of Multilateral Institutions}

Key multilateral organizations were established during this period in anticipation of the international monetary and financial implications of the conclusion of the Second World War. The United Nations Monetary and Finance Conference or Bretton Woods Conference in 1944 in Bretton Woods, New Hampshire was held where the International Bank for Reconstruction and Development (IBRD) which would later become a part of the World Bank Group as well as the International Monetary Fund (IMF) were created. Their creation specifically supported the European economies devastated by war.

\section{Marshall Plan of 1948}

Another reference point for the United States was the support of its allies with the European Recovery Program (ERP) or the Marshall Plan of 1948. The Marshall Plan (1948) proposed by U.S. Secretary of State George C. Marshall in 1947 was part of a larger world recovery plan by the U.S. government and called for European countries to participate in a joint program of reconstruction (means of production, international trade) in exchange for U.S. financial support. The aid was for the purpose of assisting European countries in adjusting to post-war conditions. The offer was extended along the two blocs, with the Western countries accepting it and Eastern European ones who were the Soviet Union and its allies not. According to Robert D. Schulzinger (1990), the Marshall Plan (1948) evidenced U.S. Cold War policy of containment with the assertion that:

[T] he beauty of Marshall's plan was that it did not appear on the surface to be directed against the Soviet Union. The secretary of state never mentioned the dangers of communism or the Soviet 
Union, and he opened the program to all European nations. He

knew, however, that the Soviet Union would reject the invitation as

a transparent attempt to penetrate Eastern Europe with American

commerce. The State Department expected the Soviets to prohibit

their Communist-dominated governments of Eastern Europe from

joining others for aid. The onus for dividing Europe into two

hostile camps would fall on Moscow, not Washington. ${ }^{62}$

Schulzinger's remarks suggested that the Soviets were to blame for the Cold War through the influence of aid from the U.S.-backed Marshall Plan.

The Organisation for European Economic Cooperation (OEEEC) and The Organisation for Economic Co-operation and Development (OECD)

The Organisation for the European Economic Cooperation (OEEC; 1948)

originated in the Marshall Plan and the Conference of Sixteen or Conference for European Economic Co-operation. ${ }^{63}$ The OEEC was established by the Conference for European Economic Co-operation (Conference of Sixteen) to administer the Marshall Plan's European Recovery Program for the joint recovery and restoration of European economies and allocation of U.S. financial aid in the form of Marshall Aid dollars. ${ }^{64}$ The

${ }^{62}$ Schulzinger, Robert D. (1998). U.S. Diplomacy Since 1900. Oxford, UK: Oxford University Press, 209-210.

${ }^{63}$ Organisation for Economic Co-operation and Development (OECD) (n.d.). "Organisation for European Economic Co-operation.” (webpage). Accessed on November 25, 2014. http://www.oecd.org/general/organisationforeuropeaneconomicco-operation.htm

${ }^{64}$ Participants received 11,800,000,000 dollars between 3 April 1948 and 31 June 1950 (Britain 24\%, France $20 \%$, Italy $11.1 \%$, FRG $11 \%$ ). Ibid. 
OEEC had 18 participating countries, and zones and put forth plans and proposals for the integration of European economies. The OEEC had a hand in the creation of the European Productivity Agency (1952) and European Nuclear Energy Agency (1957) as well as the framework for setting up a European Free Trade Area (1957). ${ }^{65}$

By 1960, the EEEC included the United States and Canada and the same year the creation of the Development Assistance Group (DAG) ${ }^{66}$. Led by the United States, the DAG served as a forum of aid donors of assistance to less-developed countries. When the OEEEC was reformed as the OECD in 1961, the DAG became the Development Assistance Committee (DAC). OECD then included non-European member countries. The DAC began to collect data on flow of bilateral aid from committee members to recipient countries ${ }^{67}$ These same recipient countries subsequently became eligible Official Development Assistance (ODA) recipients by 1961.68

\footnotetext{
${ }^{65}$ Ibid.

${ }^{66}$ Belgium, Canada, France, Germany, Italy, Portugal, the United Kingdom, the United States and the Commission of the European Economic Community. The Japanese government was immediately invited to participate in the work, and the Netherlands joined the DAG in July. Organisation for Economic Cooperation and Development (OECD) (2006). "DAC in Dates: The History of OECD's Development Assistance Committee.” Access July 28, 2014. http://www.oecd.org/dac/1896808.pdf.

${ }^{67}$ All countries and territories in Africa except South Africa; America except the United States and Canada; non-Communist Asian and Oceanic countries except Australia, Japan and New Zealand; Europe: Cyprus, Gibraltar, Greece, Malta, Spain, Turkey and Yugoslavia.

${ }^{68}$ Organisation for Economic Co-operation and Development (OECD). (n.d.). "History of DAC Lists of Aid Recipient Countries." (webpage). Access on November 25, 2014. http://www.oecd.org/dac/stats/historyofdaclistsofaidrecipientcountries.htm\#Origins.
} 


\section{U.S. President Harry Truman's 1949 Inaugural Address}

In President Harry Truman's 1949 Inaugural Address, Truman presented the idea that development assistance should come primarily from the North as represented by the United States, other developed European states and the UN to each other and by extension the developing world. Specifically, Truman spoke about Americans (from the United States) and Europeans as the standard bearers of "civilization" with the responsibility of "contributing once more to the security and welfare [after the Second World War] of the world." Excerpts on this line of thinking include:

Almost a year ago, in company with 16 free nations of Europe, we launched the greatest cooperative economic program in history. The purpose of that unprecedented effort is to invigorate and strengthen democracy in Europe, so that the free people of that continent can resume their rightful place in the forefront of civilization and can contribute once more to the security and welfare of the world (Truman, 1949, para 28).

This means [programs for world economic recovery], first of all, that we must keep our [US] full weight behind the European recovery program. We are confident of the success of this major venture in world recovery. We believe that our partners in this effort will achieve the status of self-supporting nations once again. ${ }^{69}$

\footnotetext{
${ }^{69}$ Truman, Harry (1949). "Inaugural Address.” Speech, Washington, DC, January 20, 1949. Harry S. Truman Library and Museum. para 35. Accessed November 26, 2015. http://library.menloschool.org/chicago/speech.
} 
Several expectations regarding the European "aid recipients" and their economies were conveyed through Truman's statements: (a) European states are "partners," not "aid recipients;" (b) European states' economies can recover and become "self-supporting," and (c) it was the responsibility of the United States to reaffirm Europe's "rightful place" to lead - alongside the United States — the rest of the world: Africa, Asia, and Latin America. Truman's statements supported the approach of Northern assistance to other Northern countries, and foreshadowed how the North would proceed with North-South cooperation.

In addition to advocating for European economic progress, Truman also contributed to the "making of the Third World" (Escobar). This was accomplished when he identified the need for the "underdeveloped" areas of the world to be developed by the North, with the United States taking the lead in the effort. The four point programmatic action under the guise of peace and freedom were outlined. It proposed a role for the United States and the United Nations to bring the benefits of "industrial" and "scientific" progress to the underdeveloped areas of the world (Truman). The following are excerpts from Truman's Address on this issue:

The United States is pre-eminent among nations in the development of industrial and scientific techniques. The material resources which we can afford to use for the assistance of other peoples are limited. But our imponderable resources in technical knowledge are constantly growing and are inexhaustible. I believe that we should make available to peace-loving peoples the benefits of our store of technical knowledge in order to help them realize their aspirations for 
a better life. And, in cooperation with other nations, we should foster capital investment in areas needing development.

Our aim should be to help the free peoples of the world, through their own efforts, to produce more food, more clothing, more materials for housing, and more mechanical power to lighten their burdens.

We invite other countries to pool their technological resources in this undertaking. Their contributions will be warmly welcomed. This should be a cooperative enterprise in which all nations work together through the United Nations and its specialized agencies wherever practicable. It must be a worldwide effort for the achievement of peace, plenty, and freedom.

With the cooperation of business, private capital, agriculture, and labor in this country, this program can greatly increase the industrial activity in other nations and can raise substantially their standards of living. ${ }^{70}$

Two key ideas on the future of development cooperation are inherent. First, the idea that Northern states and institutions should collectively help the underdeveloped help themselves. It held a role for the North in the affairs of the South. Second, it simultaneously pointed to a "common identity"71 among developing countries and regions predicated on their level of development. De facto discourse on the topic of

\footnotetext{
70 Truman (1949). par 47-51.

${ }^{71}$ Morais de Sa e Silva, Michelle (2010). "How Did We Get Here? The Pathways of South-South Cooperation" in "South-South Cooperation? The Same Old Game or a New Paradigm?." Poverty in Focus edited by Rathin Roy and Melissa Andrade, International Policy Centre for Inclusive Growth, Bureau for Development Policy, UNDP, 25: 3.
} 
developed countries and regions (i.e., "North") versus developing or underdeveloped ones (i.e., "South") could be made for the purpose of comparison.

\section{Principal-Agent Model of Development Cooperation}

The OECD-DAC initial model of development cooperation was premised on a Principal-Agent model of development cooperation. With this model, the "principals" are equated with donors and "agents" developing countries. According to Gore (2013), donors use "money," "conditionality," and "advice" to "persuade," "buy," or "force" developing countries to "implement" policies donors believe they need. ${ }^{72}$ This top-down model of development for developing countries of the South reinforced a subordinate status relative to the North and trajectory outlined for Southern countries to seek out and emulate Northern development.

\section{SIGNIFICANCE AND ASSUMPTIONS}

Much has been written about the contentious development relationship between the North and the South as well the long history of cooperation between countries and regions of the South. There has been limited empirical study of South-South cooperation within the Global South ${ }^{73}$ as compared with North-South cooperation. I aimed to address this gap in the literature by exploring the benefits, challenges, and strategic rationale for the application of SSC framework to Brazil and Haiti.

\footnotetext{
${ }^{72}$ Gore (2013). 773.

${ }^{73}$ Dreher, Axel; Nunnenkamp, Peter; Thiele, Rainer (2011). “Are 'New' Donors Different? Comparing the Allocation of Bilateral Aid between Non-DAC and DAC Donor Countries." World Development, 39(11).
} 
This study is significant because it targets the diversity and expansion in the arena of development cooperation occurring in the South despite the developing countries significant, on-going development challenges. Specifically, poverty remains an issue in the Global South. "[R]ecent research shows that 72 per cent of the world's poor, or 960 million people, live in middle-income countries, while only one quarter, roughly 370 million, live in low-income countries" ${ }^{\text {"74 }}$ Development remains a problem for the South; thus, the findings of this study can provide data and information for decision-making in the area of development cooperation between countries in the Global South.

According to Quadir (2013), South-South cooperation has the potential of "constructing a new aid paradigm that focuses more on the strategic needs of the partner countries than on advancing the ideological interests of the donor countries."75 The diversification of development practices and choices by the South suggests a level of competition or choice not possible before due to the economic and political position of the Global South. The motivation for the South to engage in development cooperation differs from previous development eras. Their formerly restrictive economic and political conditions have changed given their gross national products and thus their representational impact within international fora. The findings of the study may be able to provide insights into the mechanisms involved when countries engage in South-South cooperation.

\footnotetext{
${ }^{74}$ United Nations (2011). 6.

${ }^{75}$ Quadir (2013). 321.
} 
However, the study was guided by the basic notion that national interests drive development cooperation between and on behalf of states in the South. ${ }^{76}$ North-South and South-South cooperation models have an empirical foundation in the preservation of national interests thus both models can be expected to similarly seek to promote and preserve their national interests. ${ }^{77}$ Self-interest, and not ethical responsibility, explains the existence of South-South cooperation. ${ }^{78}$ This dissertation proceed from the assumption that Global South countries engage in South-South cooperation because of national interests.

On the matter of decision-making in international relations, L. Andy Afinotan wrote that decision making "deals with the trends which lead to or build up into choices and consensus. It analyses [sic] the relationships among policy makers, between them and the public, between officials and the press and between goals and issues... Decisions lead to policy, produce conflict and foster cooperation." 79 It is also assumed that the state and the international system are a "natural framework" for analyzing and understanding

\footnotetext{
${ }^{76}$ Cabral, Lidia and Weinstock, Julia (September 2010). "Brazilian Technical Cooperation for Development." Drivers, Mechanics and Future Prospects. ODI. Accessed November 16, 2015. https://www.odi.org/sites/odi.org.uk/files/odi-assets/publications-opinion-files/6137.pdf.
}

\footnotetext{
${ }^{77}$ Cabral, Lidia and Weinstock, Julia (September 2010). "Brazilian Technical Cooperation for Development." Drivers, Mechanics and Future Prospects. ODI. Accessed November 16, 2015. https://www.odi.org/sites/odi.org.uk/files/odi-assets/publications-opinion-files/6137.pdf.; Dauvergne, Peter and Farias, Deborah B.L. (2012). "The Rise of Brazil as a Global Development Power." Third World Quarterly, 33(5): 903-917.; United States Agency for International Development (USAID). (2011). USAID Policy Framework 2011- 2015. Washington, D.C.: USAID.

${ }^{78}$ Mohan, Giles (2016). "Emerging Powers in International Development: Questioning South-South Cooperation." In The Palgrave Handbook of International Development, Palgrave Macmillan UK, 279296.

${ }^{79}$ Afinotan, L. Andy (2014). "Decision-making in International Relations: A Theoretical Analysis." Canadian Social Science, 10(5): 250.
} 
decision making by decision makers. ${ }^{80}$ Applying this line of logic to decision-making in international relations to the SSC framework between Brazil and Haiti, both countries choose to engage in South-South cooperation because the context by which its decision makers make their decisions would anticipate benefit from their bilateral relationship that support their national interests. The overall assumption was that Brazil and Haiti engage in South-South cooperation because it is in their self-interest to do so.

\section{THEORETICAL FRAMEWORK}

In this dissertation, I took an instrumental versus conceptual view of development cooperation between Southern development providers and development recipients by identifying development cooperation in concrete terms: (a) peacekeeping operations, (b) technical assistance, (c) humanitarian assistance, and (d) commercial interests. When operationalizing development cooperation in this manner, it allows a way of examining the impact of the SSC framework as strengthened, weakened, or of no impact over the course of two countries' bilateral relationship. Specifically, a convergence of factors led to the prioritization of Haiti as a development partner by Brazil in the early 2000s and subsequent vitalization of their SSC framework and development cooperation between 2004 and 2017.

For Brazil, the Lula administration took a more assertive and proactive foreign policy position that included the use of the Brazilian military to accomplish United

\footnotetext{
${ }^{80}$ Ibid.
} 
Nations peacekeeping to accomplish their regional and global aspirations. ${ }^{81}$ Brazil's activism came after an important juncture in Inter-American relations with the consolidation of "South America" separate from "Latin America" in the early 1990s that set up the context for Brazil to pursue a Southern Cone-based approach to regional integration, regional defense and peacekeeping cooperation through political integration. ${ }^{82}$ Haiti provided an opportunity for former military authoritarian states to "refocus" and "recivilianize" their governments and militaries on external rather than internal security issues ${ }^{83}$ and provided Brazil the ability to project an image of a global power ready to take a more active role at the international level. President Lula's minister of foreign relations Celso Amorim articulates the importance Brazil's participation in MINUSTAH on the question of peace as an international good:

Our participation in the UN mission in Haiti also arises from the principle that peace is not a free international good: the maintenance of peace has a price. That price is participation. To be absent from or to evade giving an opinion or to act in a crisis situation can signify exclusion from the

\footnotetext{
${ }^{81}$ Sotomayor Velazquez, Arturo C. (2013). "Democratization and Commitment to Peace: South America's Motivations to Contribute to Peace Operations." in South America and Peace Operations: Coming of Age edited by Kai Michael Kenkel, London and New York: Routledge, 54.

${ }^{82}$ Marcondes de Souza Neto, Danilo (2013). "Regional Defense Integration and Peacekeeping Cooperation in the Southern Cone" in South America and Peace Operations: Coming of Age edited by Kai Michael Kenkel, London and New York: Routledge, 68.

${ }^{83}$ Bruxton, Julia D. (2013). "Swimming Against the Tide: Venezuela and Peace Operations" in South America and Peace Operations: Coming of Age edited by Kai Michael Kenkel, London and New York: Routledge, 171-172.
} 
decision making process or worse, dependency in relations to other states and regions. 84

Amorim's statement suggested that Brazil's participation in MINUSTAH addresses the collective goods problem while at the same time asserting Brazilian influence.

At the same time, Haiti provided the context for Brazil to exercise regional and international leadership as it faced severe issues of security. According to Gregg Beckett in "Rethinking the Haitian Crisis" in The Idea of Haitian Crisis, the international response to crises in Haiti has been the repatriation of those Haitians who flee the country and international intervention (humanitarian, international-designed economic and political policies and foreign military intervention). ${ }^{85}$ MINUSTAH emerged from the controversy sounding the ouster of Haitian President Jean-Bertrand Aristide and establishment of a transitional government in 2004. Previous UN missions in Haiti were under Northern leadership; however, MINUSTAH leadership was led by Brazil and a mostly Latin America peacekeeping contingency. The humanitarian situation in Haiti continued to worsen, especially after a category 7.0 earthquake hit the already impoverished island, resulting in the deaths of over 200,000 people and effecting an estimated 3 million people in January $2010 .{ }^{86}$ Though MINUSTAH's main concern has been security, its development and humanitarian activities increased especially after the

\footnotetext{
${ }^{84}$ Kenkel, Kai Michael (2013). "Out of South America to the Globe: Brazil's Growing Stake in Peace Operations" in South America and Peace Operations: Coming of Age. edited by Kai Michael Kenkel, London and New York: Routledge, 96.

${ }^{85}$ Beckett, Greg (2013). "Rethinking the Haitian Crises." in The Idea of Haiti: Rethinking Crises and Development. edited by Millery Polyné. University of Minnesota Press, 27-49.

${ }^{86}$ World Concern (2011). "Haiti Earthquake Facts and Figures.” (webpage). Accessed Janary 20, 2017. http://reliefweb.int/report/haiti/haiti-earthquake-facts-and-figures.
} 
2010 earthquake. ${ }^{87}$ William Michael Reisman argued that "credibility or legitimacy" of the UN and the United States were at risk if people perceived that free and clear elections could not be protected. ${ }^{88}$ Thus, the confluence of Haitian security, economic, political, and electoral issues in 2004 anchored the attention and intervention of the international community in particular thus introducing development cooperation by Brazil comprised of peacekeeping operations, technical assistance, humanitarian assistance and commercial interests. In the analytical chapters, the current researcher will further explore the rationale behind Brazil and Haiti's bilateral relationship.

\section{RESEARCH FRAMEWORK AND METHOD}

The purpose of this study was to examine the overall cooperation framework between Southern countries through the central question of why Southern countries engage in South-South cooperation. Southern countries engage in development cooperation with each other despite domestic challenges and the possibility of NorthSouth cooperation and alliances to strengthen their positions. Further, the North-South framework remains the prevailing framework in the area of development cooperation.

According to Fahimul Quadir, the SSC framework driven by the BRIC countries has the potential of developing a new paradigm of aid that deviates from the more conditionality-driven motivation of the North-South framework ${ }^{89}$ however, there is

\footnotetext{
${ }^{87}$ Greenburg, Jennifer (2013). "The "Strong Arm" and the "Friendly Hand": Military Humanitarian in Postearthquake Haiti” Journal of Haitian Studies, 19(1): 95.

${ }^{88}$ Reisman, W. Michael (1995). "Haiti and the Validity of International Action.” Faculty Scholarship Series, Paper 884.

${ }^{89}$ Quadir (2013).
} 
limited empirical study of South-South cooperation within the Global South. ${ }^{90}$ Countries in the Global South who engage in South-South cooperation do not follow traditional mechanisms, underscoring the need to further explore the SSC framework. ${ }^{91}$ According to Baranyi, Feldmann, and Bernier (2015), South-South cooperation has both strengths and weaknesses that are primarily unexplored in empirical studies. Baranyi et al. contended that the SSC framework is not necessarily an improvement of the North-South framework, but only an alternative to the more traditional approach to the provision of economic and political aid.

This study addresses a void in the development literature that has not devoted much time to understanding or measuring the impact of this framework on the development of countries in the South that were and still are beneficiaries of assistance from the North. I examined the promise and the shortcomings of South-South cooperation through the lens of the impact of South-South cooperation on development cooperation. The specific problem was that it is not known how the SSC framework is beneficial, challenging and strategic for the development cooperation between Southern countries. Based on this gap in the literature, I specifically explored why Brazil and Haiti engage in South-South cooperation, including how this framework is beneficial, challenging, and strategic to both countries. Case study research is used when flexibility, comprehensiveness, and complexity are present or needed to understand a phenomenon as well as when investigating "how?" and "why?" questions.92 The total sample size for

\footnotetext{
${ }^{90}$ Dreher et al. (2010).

${ }^{91}$ Quadir (2013).

92 Yin, Robert K. (2014). Case Study Research: Design and Methods. Thousand Oaks, CA: Sage.
} 
the study was 16 participants. For the semi-structured interviews, a combination of past and present leaders and officials from Haiti and Brazil participated. For the seven-item open-ended survey, scholar-practitioners on Latin America, Brazil and Haiti participated. I collected data using semi-structured interviews, open-ended surveys and archival data sources.

I used components of development cooperation-(a) peacekeeping operations, (b) technical assistance, (c) humanitarian assistance, and (d) commercial interests- to examine whether the SSC framework strengthens, weakens or has no impact on development between two Southern countries. The way in which the international development strategies works for the Global South depends on whether the country under study is a development provider or development recipient or development equals (MICMIC or LIC-LIC). In this dissertation, Brazil served as predominately the development provider and has employed a number of leadership strategies around peacekeeping, South-South and regional fora such as the BRICS, IBSAs and development banking including the IBSA fund, New Development Bank (formerly BRICS Bank), and the Brazilian National Development Bank or BNDES. Haiti is the development recipient whose international development strategies focus on its participation in the development of actions plans for its national recovery and development and poverty reduction plans led by multilateral entities such as the Haiti Reconstruction Fund (HRF). Additionally, Haiti's concerted willingness and efforts to secure foreign investments in 2011 under the slogan "Haiti is open for business" is also considered an international development strategy that did not preclude Southern states. The main hypothesis was that the SouthSouth cooperation affects development cooperation by strengthening, weakening or 
having no impact on development in Brazil and Haiti. Figure 1 below provides a visual presentation of the intended direction of the research framework:

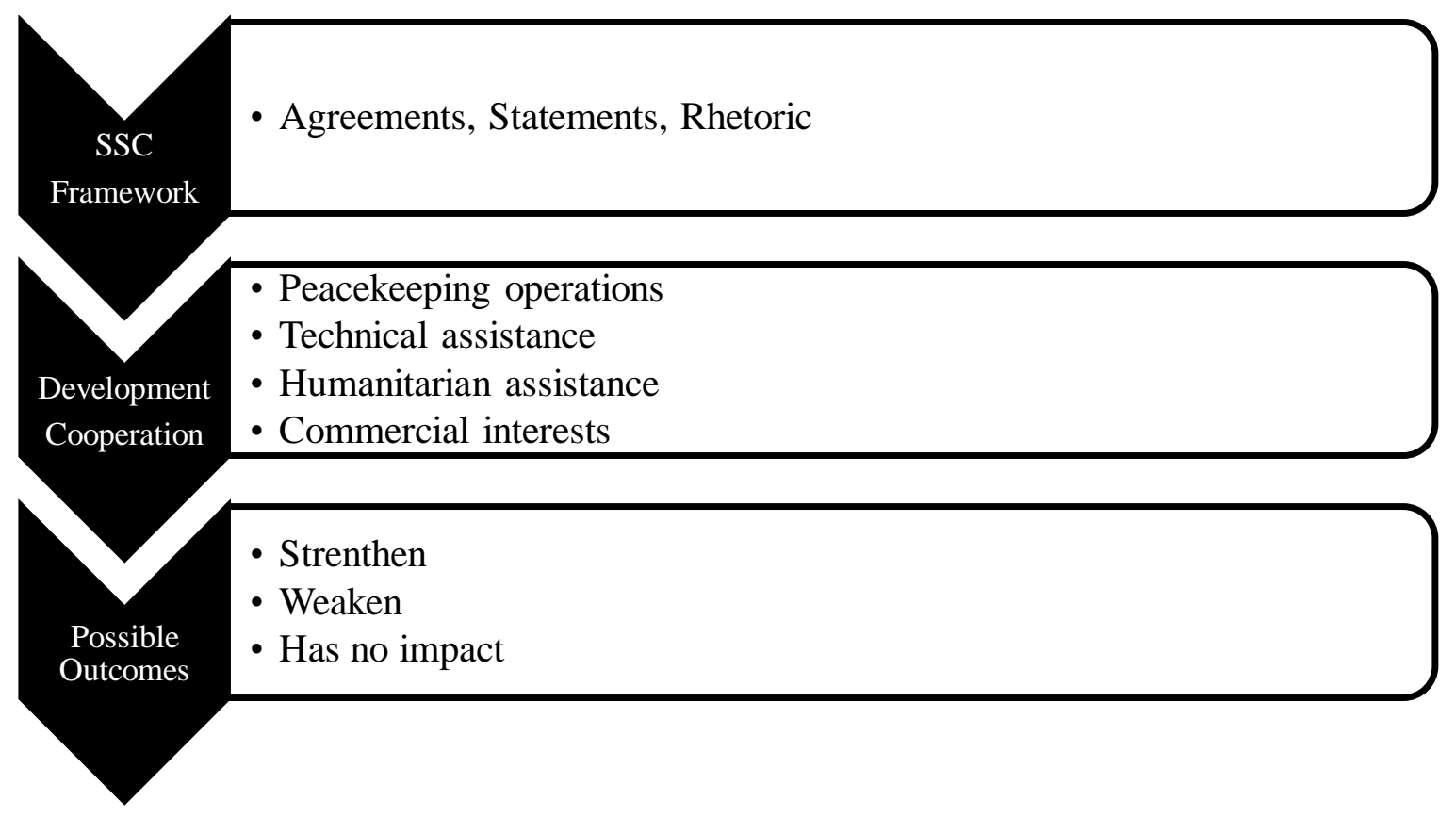

Figure 1. Intended direction of the research framework.

I developed three sub-questions of the study to examine the impact of the SSC framework and its likely outcome on development for the case countries:

1. How do Brazil and Haiti benefit from engaging in the South-South cooperation framework?

2. How challenging is the SSC framework for Brazil and Haiti?

3. How is engaging in the SSC framework strategic for both Brazil and Haiti? Addressing these questions is a descriptive task when examining benefits, challenges, and strategic rationale for the Brazil-Haiti SSC framework. 
Qualitative methods involve the use of tools that will lead to rich and detailed data to explain a phenomenon. ${ }^{93}$ The interconnected relationship between phenomenon and context is one of the key features that define case study research. Thus, this study gathers data through several methods. The first contribution of data comes from an explanatory framework that serves as a review of the literature that situates South-South cooperation within the discourse surrounding the emerging donor challenge to the traditional aid architecture for development assistance and the nature of South-South cooperation in Latin America. The second contribution of data stems from a qualitative exercise whereby I interviewed and surveyed leading experts and practitioners engaged in BrazilHaiti cooperation who have experience in being involved in making decisions or implementing policies pertaining to South-South cooperation or have relevant experience and knowledge of South-South cooperation in Brazil, Haiti or Latin America.

Specifically, I collected data using semi-structured interviews with past and present Brazilian and Haitian career diplomats, high-level government officials, advisors, consultants, political appointees and academics. I administered a seven-item open-ended survey of scholar-practitioners on Latin America, Brazil and Haiti. Given Haiti’s longstanding relationship to the United States and multilateral organizations, several survey respondents also included officials from the World Bank, the U.S. government and contractors. The final contribution included archival data sources including government records, newspapers, speeches, and press releases and academic writings.

\footnotetext{
93 Taylor, Steven J., Bogdan, Robert and DeVault, Marjorie (2015). Introduction to Qualitative Research Methods: A Guidebook and Resource. Hoboken, NJ: John Wiley \& Sons.
} 
The study's respondent pool was focused on elite and expert-level interviewees ${ }^{94}$ because of their ability to structure accounts on the topic of South-South cooperation and what is considered important and relevant for consideration in a research study. This group is an authority on South-South cooperation due to their specialized knowledge and decision-making functions past and present as political, government, and academic experts. Many have assumed responsibilities and carried out actions for and on behalf of the state.

Also, in compliance with case study research design, three or more data sources are adequate for triangulation and to generate a detailed description of the phenomenon and context of the study. ${ }^{95}$ I used archival data sources including government records, newspapers, speeches, and press releases to place the data and information collected from the aforementioned sources enable me to understand and contextualize the connection between South-South cooperation and the ensuing issues of development cooperation for Brazil and Haiti. The methods of explanatory framework, in-depth interviews, survey questionnaires and archival data served to address the hypothesis that the South-South cooperation affects development cooperation by strengthening, weakening or having no impact on development in Brazil and Haiti.

\footnotetext{
${ }^{94}$ Dexter, Lewis (2006). Elite and Specialized Interviewing. University of Essex, Colchester, UK: ECPR Press - ECPR classics.

${ }^{95}$ Yin (2014).
} 


\section{HYPOTHESIZED OUTCOME AND OVERVIEW OF DISSERTATION}

Overall, it is expected that South-South cooperation affects development in the Global South if one looks at the volume of technical agreements, policy statements and political rhetoric about the importance of South-South cooperation by Northern and Southern actors. The soundness of the SSC framework as a strategy for development is an important consideration when the outcome on development most likely differ when it is a MIC-LIC partnership, the return on investment is not highly instrumental for the development provider, and development remains a problem in the Global South when over $70 \%$ of the world's poor live in middle income countries. Comparatively speaking, Brazil, China, India, South Africa are not immune to many of the development issues their recipient partners face. This again raises the central question of why Southern countries engage in South-South cooperation when each of the emerging donors have development problems of their own and the North remains the primary dispenser of development assistance to buttress their development. Though it is hypothesized that the South-South cooperation framework affects development cooperation it is expected that the effect will strengthen development cooperation because the framework has not been based entirely on domestic conditions. The remaining chapters are dedicated to examining the Brazil-Haiti SSC framework in order to examine its role and impact on their development cooperation.

\section{Chapter Overview}

Chapter Two provides an explanatory framework that situates the topic of SouthSouth cooperation within a trajectory of literatures on the emerging donor challenge, 
discourse on development cooperation, and the nature of South-South cooperation in Latin America. Chapter Three specifies the research method employed in the dissertation that includes the data collection, data analysis, assumptions, and limitations of the study. Chapter Four presents the findings of the data analysis, which captures the nature of Brazilian and Haitian engagement in South-South cooperation through the perspectives and experiences of the study respondents. Chapter Five includes a deeper discussion of the findings presented in previous chapter. The discussion will focus explaining the hypothesized relationship between South-South cooperation and development cooperation and address the study's central research question and overall contributions of the study. Chapter Six serves as the conclusion, in which I look at the implication of the findings on development cooperation in Haiti by Brazil. The chapter aims to contribute to rethinking development through South-South cooperation in Latin American and Caribbean, and by extension, the Global South. 


\section{CHAPTER 2}

\section{THE EXPLANATORY FRAMEWORK}

\section{INTRODUCTION}

This chapter serves as an explanatory framework based on literature that contextualize expanding notions of South-South cooperation as an alternative development strategy for developing countries of the Global South in order to contribute to the explanation for why Southern countries engage in South-South cooperation. The works of scholars and practitioners of South-South cooperation are covered as well as development cooperation. Two major themes in the literature shed light on what is known about the potential of the SSC framework: (a) discourse surrounding the emerging donor challenge to the traditional aid architecture and (b) the nature of South-South cooperation in Latin America.

The aim of focusing the literature review in this manner was to highlight the perspectives of scholars and practitioners in the literature on South-South cooperation and Southern donors and contrasting Northern perspectives for comparative purposes. The chapter concludes with an overview of those aspects of the literature that I used to explain Southern countries engagement in South-South cooperation. Before reviewing the literature based on the major themes, I will begin with an explication of the term Global South and will address the main issues that differentiate the thinking of scholars and practitioners from the North and the South. 


\section{EXPLICATION OF GLOBAL SOUTH}

Bullard offered a binary explanation of the Global South as a political concept and political actor. ${ }^{96}$ As a political concept, the Global South reflects and informs the conditions resulting from "global patterns of domination and resistance" and as a political actor "all groups with a common experience of exploitation, alienation, and marginalization under neoliberal globalization, both the dominated and the resisters." ${ }^{97}$ This view of the "global South" takes the concept outside of strict notions of geographical location, economic theory or government policy because this collectivity represents states with different systems of governance and development positions from middle income to least developing located in the regions of Africa, Asia, and Latin America. In the work of Marco Antonio Vieira and Chris Alden, a similar line of thinking to that of Bullard can be found when discussing India-Brazil-South Africa Dialogue or the IBSA's as a political actor(s) who choose to employ the term the South as a political concept that represents their "mobilizing symbol" and "ideological expression" of their governments unique development challenges..$^{98}$

Matthew Sparkle recasted the Global South as a concept-metaphor that "reterritorializes global space in the interests of repossession by the dispossessed" and that is "located at the intersection of entangled political geographies of dispossession and repossession." 99 This notion of the Global South served the function of a euphemism for

\footnotetext{
${ }^{96}$ Bullard, Nicola (2012). "Global South, the Concept of." In Encyclopedia of Global Studies, edited by Mark Juergensmeyer and Helmut K. Anheier. Thousand Oaks, CA: Sage Publications, 724.

${ }^{97}$ Ibid.

${ }^{98}$ Vieira, Marco Antonio and Alden, Chris (2011). "India, Brazil, and South Africa (ISBA): South-South Cooperation and the Paradox of Regional Leadership." Global Governance, 17: 510.
} 
political resistance and political resister among states and actors who have been dispossessed. Thus, this view of political resistance combined the political concept and political resister basis for the concept of political actor. Conversely, Krüger called specific attention to the common experience of colonial subjugation as an important marker of the "anticolonial identity" prevalent in the South. ${ }^{100}$ Kruger elaborated that beyond the structural aspects that define the North-South divide, “... a political analysis of the North-South conflict has to deal with the emergence of different coalitions and institutions, representing the interests of South or North in the domain of international politics." 101 This would include formulations such as the IBSA, BRICS and the Group of 77 (G77). ${ }^{102}$ The emerging economies and regional powers have pushed for changes in international governance through their collective action under the rubric of the Global South or the South.

The early 2000s witnessed a reaffirmation of the Global South's solidarity politicized outwardly through its rhetoric, policy positioning within multilateral forums and institutions and with the formulation of new institutional arrangements by and for the Global South. ${ }^{103}$ Leading emerging economies and regional powers emerged as the

\footnotetext{
${ }^{99}$ Sparkle, Matthew (2007). "Everywhere but Always Somewhere: Critical Geographies of the Global South.” The Global South. 1(1): 117.

${ }^{100}$ Krüger, Lydia, "North-North, North-South and South-South Relations," in Global Transformation and World Futures: Knowledge, Economy, and Society, 1 edited by Sohail Inayatulah, Oxford: EOLSS Publishers, 344.

${ }^{101}$ Ibid. 344.

102 The G77 is a group of 134 developing countries originally founded in 1964 as seventy-seventy developing countries within the auspices of the United Nations. The G77 seeks to articulate, promote and negotiate economic interests and promote South-South cooperation for development. See The Group of 77 at the United Nations (n.d.). "About the Group of 77." http://www.g77.org/doc/index.html.

${ }^{103}$ Vieira and Alden (2011). 510-511.
} 
spokespersons for the Global South through their criticism of the established international system of governance and efforts to reform it through negation and reform including the International Monetary Fund (IMF), the World Bank and the UN Security Council. Vieira and Alden called this a "new wave of politicization" that challenges the North and represented the type of Third World solidarity of the 1970s. ${ }^{104}$

The question of how well regional hegemons such as Brazil, China, India, and South Africa serve as Global South spokespersons of other developing countries in their respective regions and among LDCs and LIC in particular is problematic. Unlike the formative years of solidarity, the Global South is comprised of a mix of states and regions with different economic and development positions. Despite the fact that countries of the Global South share a common history and identity, the introduction of middle income countries and regional powers that heretofore did not exist to the level they do today (politically and economically) under the rubric of "developing" brought about an emergent paradox with respect to their motives by neighboring states in their regions.

According to Vieira and Alden, the end of the Cold War provided an opportunity for the South's emerging powers to gain legitimacy, leadership, and soft power through their interaction with each other, while at the same time purporting to represent the interests of all developing countries. ${ }^{105}$ The regional leadership role of the IBSA states has been embraced by Northern powers however less so by the neighboring countries in their respective regions. "The diplomacies of Brazil, India and South Africa have faced varied degrees of resistance from weaker neighbors while attempting to assert regional

\footnotetext{
104 Ibid.

105 Ibid. 514
} 
influence. India poses the most complex case in South Asia in terms of its long-standing conflict with Pakistan and strategic competition with China. Brazil's and South Africa's regional leadership roles are also far from consolidated." 106 Vieira and Alden follows that Brazil's investment in "regional public goods" has demonstrated relative progress. ${ }^{107}$

The paradox is that certain Southern countries like Brazil, China, India, and South Africa have been accepted as regional leaders by Northern powers and multilateral institutions, although the states they appear to lead tend to resist for geopolitical, geostrategic reasons. Pinheiro and Gaio (2014) stated that Brazil exercises two different leadership forms: inwards regional leadership and outwards regional leadership.108 Inwards regional leadership is informed by Brazil's ability to articulate rules and patterns of behavior in South America and outwards regional leadership defines its ability to leader other regional partners on global level issues. ${ }^{109}$ In a sense, Brazil regards itself as a regional leader without necessarily garnering being viewed as such by its neighbors. ${ }^{110}$ The competing approaches to coalition-building among states in South America between Brazil and Venezuela points to the paradox of leadership within the Global South in South America in the 2000s. According to Burges (2007), Brazil takes a pragmatic, market-friendly, self-interested view of creating economic opportunities by way of state supported national firms in the spirit that its efforts may also benefit their

\footnotetext{
${ }^{106}$ Vieira and Alden (2011), 514.

${ }^{107}$ Ibid. 514.

${ }^{108}$ Pinheiro, Leticia and Giao, Gabrieli (2014). "Cooperation for Development, Brazilian Reginal Leadership and Global Protagonism.” Journal of the Brazilian Political Science Association, 8(2): 9.

${ }^{109}$ Ibid.

${ }^{110}$ Ibid.
} 
regional partners. ${ }^{111}$ Brazil wants South America to serve as a market and resource site to meet the needs of its economy. ${ }^{112}$ "The neostructuralist state is not charged with bringing about results, but with clearing barriers - resulting either from market failure or excessive interventionism - to private sector activities in the selected areas and providing a small measure of protection during the unstable initial years." ${ }^{\prime 13}$ In addition, Brazil has made it a point to engage and negotiate with and on the behalf of other Southern countries through formulations including the BRICS, G20, ISBA, and the World Trade Organization (WTO).

Alternatively, Venezuela's approach to coalition-building is less market-driven and more socialist through its historical and contemporary use of petroleum with its partners to fuel an overtly leftist hemispheric vision of Latin American unity based on a Bolivarian solidarity and ODA. ${ }^{114}$ The manner in which each country is inserted in the global political economy is what anchors their vision of Latin American and Southern relations vis-a-vis the global system. ${ }^{115}$ Burges (2007) cited that each country's vision makes obtaining regional leadership nearly a defensive necessity and argued that Brazil's emphasis on independent business decisions is more sustainable than Venezuela's statist strategy. ${ }^{116}$

\footnotetext{
111 Burges (2007). 1344.

112 Ibid. 1344.

${ }^{113}$ Ibid. 1349.

${ }^{114}$ Ibid. 1344.

115 Ibid.

116 Ibid. 1344-1355.
} 
Bullard, Vieira and Alden, Sparkle, and Krüger each contributed to some aspect of the political concept-political actor binary explication of the Global South and provides a useful tool for describing the immaterial and conceptual aspects of the Global South by giving it meaning outside of geographical location(s). However, the issue with explaining the Global South and/or the terms the South, Third World and developing countries within a political concept/political actor binary is that it does not fully capture the complexity of the interactions between Southern states or the role of the North within these interactions; thus, the ongoing paradox of southern leadership remains.

Global South network of relationships is both internal and external to the "South." There are relationships, institutions, and coalition between emerging powers such as Brazil China, India, and South Africa, and their interactions with the North and Northern institutions for and on half of themselves and the Global South. In addition, these leading powers interact with each other and other MICs and LDCs independent of the North and Northern institutions.

\section{APPROACHES TO SOUTH-SOUTH COOPERATION}

The works of scholars and practitioners of South-South cooperation have also addressed the matter of development cooperation. Bry (2016) evaluated South-South cooperation from the perspective of southern countries. This author referenced a set of "basic values, goals, structure, capacity, and forms and areas of actions" that define South-South cooperation which southern countries choose to emphasize and weigh 
differently in their implementation. ${ }^{117}$ Additionally, Bry cited that Southern countries also purport principles and approaches around South-South development cooperation ${ }^{118}$ that prioritizes principles and approaches in a manner that is contradictory to the traditional aid paradigm, including Southern donors' absence with regard to monitoring and evaluation which is in direct conflict with Northern donors focus on "forecasting" and "aid[ing]" effectiveness. ${ }^{119}$ Conversely, the North also promulgate their view and idea of South-South cooperation. The United Nations has reported on different aspects of South-South cooperation and the role the United Nations has and should potentially play in defining the concept and typology of South-South cooperation. ${ }^{120}$ The United Nations has called for the identification of "intervention categories" such as "technical, scientific, and cultural cooperation," "humanitarian and peace cooperation," and "financial cooperation." 121 These are key areas of concern for Southern countries in their models of South-South cooperation, and areas which Brazil emphasizes in its development cooperation.

Northern donors' integration of South-South cooperation principles and approaches vis-à-vis development is problematic when it comes to implementation. ${ }^{122}$

\footnotetext{
${ }^{117}$ See "Common points of Definition as Described in the Literature" p. 4 by Sandra Bry (2016). "The evolution of South-South development cooperation: Guiding principles and approaches," Bry, Sandra. H. (January 2016). "The Evolution of South-South Development Cooperation: Guiding Principles and Approaches." European Journal of Development Research, 4

${ }^{118}$ See "SSDC Principles and Approaches as Described in the Literature" Ibid. 5.

${ }^{119}$ Ibid. 6

${ }^{120}$ United Nations Development Program (UNDP) (2008). Executive Summary South - South Cooperation - Concepts, Typology and Challenges United Nations System / Brazil. Accessed November 16, 2016. http://rss.cebri.org/213.pdf.

${ }^{121}$ UNDP (2008). 2.
} 
Bry cited the example of the incompatibility regarding Northern donors need to forecast their activities and action versus the South's "demand-driven approach," which is calls for recipient ownership (at least rhetorically). Also, Northern donors' view of "aid effectiveness" emphasizes the importance of evaluation-based framework for determining results of development, which is incompatible with Southern countries' lack of emphasis on measurement or monitoring. Bry viewed the actions of Southern countries in the area of development cooperation as a function of their historical desire to create an alternative model to the traditional aid paradigm. The incompatibility of the Global North's efforts to harmonize their principles and approaches with those of the Global South is fundamental to examining how Southern donors choose to frame their cooperation with recipient partners.

Abdenur and da Fonseca (2013) also problematize the North's ongoing engagement in South-South cooperation as the North's way of expanding its influence in development cooperation. These authors identified several ways the North engages with the South: the creation of new or reinforced South-South cooperation related fora within multilateral organizations, the promotion of triangular cooperation with Southern countries, and the "ad-hoc arrangements" for the purpose of gaining more knowledge about South-South cooperation. ${ }^{123}$ Abdenur and da Fonseca argued that the North's growing role in South-South cooperation persists despite declines in Northern aid reflects Northern donor's need to influence how Southern donors set about and conduct SouthSouth cooperation. Bry held the view that the actions of Southern countries in the area of

${ }^{122} \operatorname{Bry}(2016)$.

${ }^{123}$ Abdenur and Da Fonseca (2013). 1479. 
development cooperation serves as a function of their historical desire to create an alternative model to the traditional aid paradigm. The Global South's concern with the hegemonic influence of the Global North points to developing countries drive to implement alternative models of cooperation independent of the North. ${ }^{124}$ The issue of incompatibility between Northern and Southern approaches to development cooperation also contributes to understanding why Southern donors choose to frame their cooperation with recipient partners differently.

Gosovic (2016) took the position that the process of engaging in South-South cooperation needs updating and provided suggestions for doing so by looking at the evolution, ascendency, and experience of South-South cooperation by the South. For Gosovic, South-South cooperation as a framework is not static; thus, the prospect for improving developing countries through South-South cooperation is possible. Gosovic's position is grounded in the idea that South-South cooperation as a modality can allow for "independent action" and "initiative" by states in the South. Unlike Bry, Gosovic did not focus on the manner in which South-South cooperation differs from North-South cooperation or the comparative dilemmas that ensue from analyzing those differences over the course of the evolution of South-South cooperation. Instead, the author recommended "tapping the promise of South-South cooperation" 125 by taking lessons learned over the 5 decades of experience with South-South cooperation for the purpose of recasting South-South cooperation for a contemporary context. ${ }^{126}$ Gosovic cited the

\footnotetext{
${ }^{124}$ IBON International (2014).

125 Gosovic, Branislav. (2016). "The Resurgence of South-South Cooperation." Third World Quarterly, 37(4), 746.
} 
project of Venezuela's ALBA (Bolivarian Alliance for the Peoples of Our America) and the Forum on China-Africa Cooperation as examples of contemporary alternative SouthSouth policy frameworks from which lessons can be drawn. ${ }^{127}$ Gosovic's view of SouthSouth cooperation as an active and dynamic project pointed to the desirability for countries to seek improvement and expansion in manner that best address their current needs. As an emerging country, Brazil took South-South cooperation and made it a centerpiece of its foreign policy through a series of independent actions and initiatives at the domestic, international, and global levels.

Bry and Gosovic viewed the evolution of South-South cooperation as their starting point for examining the prospects for development cooperation; however, Milani and Echart Muñoz looked at the history of North-South cooperation. ${ }^{128}$ For Milani and Echart Muñoz, the history of North-South institutions reproduces a "status quo" within the international order; as a result; South-South cooperation has emerged among developing countries in an attempt to change it. ${ }^{129}$ Their logic supported the notion that North-South cooperation is inherently incompatible with South-South cooperation and that South-South cooperation emerges directly out of the history of developing countries efforts to change their conditions through development cooperation. The history and evolution of South-South cooperation intersects with $21^{\text {st-century socio-political and }}$

\footnotetext{
${ }^{126}$ Ibid.

${ }^{127}$ Ibid. 737.

${ }^{128}$ Milani, Carlos. R. S. and Echart Muñoz, Enara (2013). "Does the South challenge the Geopolitics of International Development Cooperation?." Geopolítica(s). Revista de Estudios Sobre Espacio y Poder. $4(1)$.

${ }^{129}$ Ibid. 37.
} 
economic realities in a manner that leads to a "promise of solidarity" and creates "incentives" for developing countries (mainly the big ones) to engage in development cooperation. ${ }^{130}$ Looking at the incentives for solidarity through South-South cooperation is especially important when considering the rationale for the application of SSC framework among countries of the Global South.

\section{EMERGING DONOR CHALLENGE TO THE TRADITONAL INTERNATIONAL AID ARCHITECTURE}

Kindornay and Samy (2012) broadly defined the international aid architecture as "the set of structures and institutions for delivering aid [that] is often described as dysfunctional and uncoordinated" that suffers from issues of "legitimacy."131 Their legitimacy is predicated on a lack of recipient country participation in their development cooperation with donors. ${ }^{132}$ This international aid architecture is lead by the International Monetary Fund (IMF), World Bank and the OECD-DAC and the participation of mainly Northern donors.

$\underline{\text { Rise of the South }}$

The early 2000s were characterized by rapid, high, and sustained economic growth rates and industrialization by developing countries such as Brazil, China, and

\footnotetext{
${ }^{130}$ Ibid. 38.

${ }^{131}$ Kindornay, Shannon and Samy, Yiagadeesen (2012). "Establishing a Legitimate Development Cooperation Architecture in the Post-Busan Era," North-South Institute. Accessed December 16, 2017. http://www.nsi-ins.ca/publications/establishing-a-legitimate-development-co-operation-architecture-in-thepost-busan-era/.

${ }^{132}$ Ibid. 1.
} 
India that resulted in a shift in global economic and political power. ${ }^{133}$ These economies are considered emerging because their presence has been felt at the global level in key sectors such as trade, investment, and development. ${ }^{134}$ The pace at which these developing economies recovered from the global economic crisis of 2008 is the meaning behind the term "rise of the South." 135

Generally, the optomistic short- and long-term economic forecasts on the Global South following the 2008 crises supported the prominence of BRICS in development circles. In 2011 and 2012, developing countries were expected to grow by $6.5 \%$ (compared with $4.4 \%$ in 2011 and $4.5 \%$ in 2012 globally) and account for almost $60 \%$ of world GDP by 2030. ${ }^{136}$ The big economies of the Global South were held as the foundation for the shift in economic and political power toward the developing countries of the South of which Brazil was considered a leader. ${ }^{137}$

\footnotetext{
${ }^{133}$ Organisation for Economic Co-operation and Development (OECD) (2013). Perspectives on Global Development 2013 Industrial Policies in a Changing World: Shifting up a Gear. Accessed October 29, 2016. http://www.oecd.org/dev/pgd/COMPLETE-\%20Pocket\%20EditionPGD2013.pdf; United Nations. (2011). The State of South-South Co-operation: Report of the Secretary-General, A/66/229. Accessed November 16, 2015. http://www.preventionweb.net/files/resolutions/N1144233.pdf.

${ }^{134}$ Ibid.

${ }^{135}$ Malik, Khalid (2013). "Human Development Report 2013: The Rise of the South: Human Progress in a diverse world." The Rise of the South: Human Progress in a Diverse World (March 15, 2013). UNDPHDRO Human Development Reports.

${ }^{136}$ United Nations Office of the High Representative for the Least Developed Countries, Landlocked developing countries and small island developing states (OHRLLS) (2011). "Harnessing the Positive Contribution of South-South Co-operation for Least Developed Countries' Development in New Delhi" Fourth United Nations Conference on the Least Developed Countries Background Paper, 18-19 February 2011. 6. Accessed November 28, 2014. http://www.un.org/en/conf/ldc/pdf/background\%20paper\%20on\%20southsouth $\% 20$ cooperation $\% 20$ for\%20ldcs\%20development-final.pdf.

${ }^{137}$ de Renzio and Seifert (2014).
} 
DAC member countries remain the primary donors of development assistance with USD $\$ 128.5$ billion a year in official development assistance to the South in $2010 .{ }^{138}$ According to the World Bank (2012), 2010 Official Development Assistance (ODA) represented a record high level; however, disbursements fell by $2.7 \%$ in 2011 , and aid effectiveness goals have not been met by DAC member countries since this high point. ${ }^{139}$ Generally, data on emerging donor development assistance is hard to find. ${ }^{140}$ When nonDAC country data are reported by the OECD, the data may come from multiple sources, account for different types of assistance across different areas, or lack consistency across reporting periods. Table 6 illustrates the intermittent and imprecise accounting of "Key Partners" concessional finance or "ODA-like flows." 141

Table 6

Estimates of Gross Concessional Flows for Development Co-operation ("ODA-like" Flows) from OECD Key Partners

\begin{tabular}{lllllll}
\hline Country & 2010 & 2011 & 2012 & 2013 & 2014 & Source \\
\hline Brazil & 500 & n.a. & n.a. & n.a. & n.a. & Institute of \\
& & & & & Applied \\
& & & & Economic \\
& & & & Research \\
& & & & (IPEA) and \\
& & & & & Brazilian
\end{tabular}

\footnotetext{
${ }^{138}$ Burges, Sean W. (2012). "Developing from the South: South-South Cooperation in the Global Development Game.” Austral: Brazilian Journal of Strategy \& International Relations, 1(2): 225.

${ }^{139}$ World Bank. (2012). Global Monitoring Report 2012: Food Prices, and the Millennium Development Goals (MDGs). Accessed July 15, 2016. http://www.imf.org/external/pubs/ft/gmr/2012/eng/gmr.pdf.

${ }^{140}$ Burges (2012).

${ }^{141}$ Organisation for Economic Cooperation and Development (OECD) (2016). "Statistics on Resource Flows to Developing Countries." (webpage). Accessed December 16, 2016. http://www.oecd.org/dac/stats/statisticsonresourceflowstodevelopingcountries.htm.
} 


\begin{tabular}{|c|c|c|c|c|c|c|}
\hline Country & 2010 & 2011 & 2012 & 2013 & 2014 & Source \\
\hline & & & & & & $\begin{array}{l}\text { Cooperation } \\
\text { Agency } \\
(\mathrm{ABC})\end{array}$ \\
\hline Chile & 16 & 24 & 38 & 44 & 49 & $\begin{array}{l}\text { Ministry of } \\
\text { Finance }\end{array}$ \\
\hline China & 2564 & 2785 & 3123 & 2997 & 3401 & $\begin{array}{l}\text { Fiscal } \\
\text { Yearbook, } \\
\text { Ministry of } \\
\text { Finance }\end{array}$ \\
\hline Colombia & 15 & 22 & 27 & 42 & 45 & $\begin{array}{l}\text { Strategic } \\
\text { Institutional } \\
\text { plans, } \\
\text { Presidential } \\
\text { Agency of } \\
\text { International } \\
\text { Cooperation }\end{array}$ \\
\hline $\begin{array}{l}\text { Costa } \\
\text { Rica }\end{array}$ & n.a. & n.a. & n.a. & 21 & 24 & $\begin{array}{l}\text { Annual } \\
\text { budget laws }\end{array}$ \\
\hline India & 708 & 794 & 1077 & 1223 & 1398 & $\begin{array}{l}\text { Annual } \\
\text { reports, } \\
\text { Ministry of } \\
\text { foreign } \\
\text { affairs }\end{array}$ \\
\hline Indonesia & 10 & 16 & 26 & 49 & 56 & $\begin{array}{l}\text { Ministry of } \\
\text { National } \\
\text { Development } \\
\text { Planning }\end{array}$ \\
\hline Mexico & n.a. & 99 & 203 & 529 & n.a. & $\begin{array}{l}\text { Mexican } \\
\text { Agency for } \\
\text { International } \\
\text { Development } \\
\text { Cooperation } \\
\text { (AMEXID) }\end{array}$ \\
\hline Qatar & 334 & 733 & 543 & 1344 & n.a. & $\begin{array}{l}\text { Foreign aid } \\
\text { reports, } \\
\text { Ministry of } \\
\text { Foreign } \\
\text { Affairs }\end{array}$ \\
\hline $\begin{array}{l}\text { South } \\
\text { Africa }\end{array}$ & 154 & 229 & 191 & 191 & 148 & $\begin{array}{l}\text { Estimates of } \\
\text { Public } \\
\text { Expenditures, } \\
\text { National } \\
\text { Treasury }\end{array}$ \\
\hline
\end{tabular}


Note. Reprinted from $O E C D$ webpage Statistics on Resource Flows to Developing Countries, Estimates of gross concessional flows for development co-operation ("ODA-like" flows).

The OECD repored that Brazil's exact figures on development cooperation is "significantly higher" than even the Brazilian government's officially published figures. This is due to bilateral peacekeeping activities and also due to Brazil not including some activities that would be considered DAC eligible. ${ }^{142}$ Specifically, DAC-ODA excludes development assistance involving private sector financing, which includes commercialpurpose loans and grants, export financing and foreign direct investment. Further multilateral institutions who are engaged in South-South cooperation from the perspective of the South may not be included on the list of ODA-eligible international organizations. As a result, critical amounts of development assistance flows by major non-DAC countries of the South such as Brazil, China, India, and South Africa are not included OECD-DAC official ODA.

The OECD has made efforts to encourage non-DAC emerging donors to become DAC member countries. The OECD referred to certain non-DAC countries as "key partners" and referenced the inclusion of their aid flow and assistance as "ODA-like." Additionally, the legitimacy gap Kindornay and Samy refer to has been addressed by the OECD through the sponsorship of High Level Fora on Aid Effectiveness in Rome (2003), Paris (2005), Accra (2008), and Busan (2011). These fora were multistakeholder events attended by recipients, emerging donors, and civil society for the purpose of better understanding why development aid is not getting desired results and to

${ }^{142}$ OECD (2016). 
coordinate efforts to meet Millennium Development Goals targets. ${ }^{143}$ However, nonDAC member countries have persistently refused to join the OECD.

Overall, Southern countries provide different types of aid including technical cooperation, bilateral peacekeeping, and "in-kind" contributions (medical equipment, personnel, training, etc.), thereby making South-South cooperation development incomparable across countries. ${ }^{144}$ An exception would be Kuwait, Saudi Arabia and the United Arab Emirates, who report their aid flows to the OECD. ${ }^{145}$ Data that indicate increases in non-DAC aid does not adequately capture the significance of emerging donor development cooperation or the degree to which the Global South is actually engaged in South-South cooperation. The difficulty in accounting for emerging donor development assistance works to absolve the emerging donors from taking greater responsibility in global aid effectiveness and accountability.

\section{$\underline{\text { Rise of Emerging Donors }}$}

Traditionally, development cooperation has been equated with official development assistance provided by OECD-DAC member countries as the primary

\footnotetext{
${ }^{143}$ OECD (2016).

${ }^{144}$ Hagedoorn, Paulien and Beets, Gijs (October 2011). "New Donor Countries." The Hague: Netherlands Interdisciplinary Demographic Institute \& United Nations Population Fund. Accessed June 26, 2016. http://resourceflows.org/sites/default/files/RF\%20Report\%20New\%20donor\%20countries\%20_Oct2011_.p df.

${ }^{145}$ Ibid.
} 
donors of development assistance ${ }^{146}$ with a narrative driven by conditionality. ${ }^{147}$ By the late 1990s, the number of non-DAC development provider countries began to increase; and according to the OECD twenty-four non-DAC providers can be identified. ${ }^{148}$ Contributors to the literature on development cooperation have made reference to emerging donors as "new development partners," "new donors," "rising donors," "Southern donors," and "Southern development actors."149 Their presence and engagement in development cooperation have been cited by Bilal (2012); Burges (2012); Cabral, Russo, and Weinstock (2014); Chandran and Cooper (2015); Chin and Quadir (2012); Dreher et al. (2010); Fues (2013); Gore (2013); Janus, Klingebiel, and Paulo (2014); Manning (2006); Milani and Echart Muñoz (2013); Smith (2011); Stuenkel (2013); The Reality of Aid (2010); Quadir (2013); and Woods (2008).

The observation has been made by Richey and Ponte (2014) and Quadir (2013) that new actors in development are not actually new to international development cooperation. The meaning of "new" in this instance signifies "newly studied" by

\footnotetext{
${ }^{146}$ Burges (2012); Gore (2013).

${ }^{147}$ Quadir (2013).

${ }^{148}$ For an analysis of non-DAC providers and their perspectives on development cooperation see the Organisation for Economic Cooperation and Development. (2014). "Non-DAC Countries and the Debate on Measuring Post-2015 Development Finance. DAC Meeting, February 10, 2014." Accessed November 26, 2014. http://www.oecd.org/dac/dac-global-relations/Non-

DAC\%20countries\%20and\%20the\%20debate\%20on\%20measuring\%20post2015\%20development\%20finance.pdf.

${ }^{149}$ Mawdsley, Emma., Savage, Laura. and Kim, Sung-Mi (2012). “A 'Post-Aid World'? Paradigm Shift in Foreign Aid and Development Cooperation at the 2011 Busan High Level Forum." The Geographical Journal, 180(1); Burges (2012); Gore (2013); Chin, Gregory and Quadir, Fahimul (2012). "Introduction: Rising States, Rising Donors and the Global Aid Regime." Cambridge Review of International Affairs, 25(4); Inoue and Costa Vaz (2012); Mawdsley, Emma (2011). "The Changing Geographies of Foreign Aid and Development Cooperation: Contributions from Gift Theory." Transactions of the Institute of British Geographers. 37(2).
} 
international development scholars. ${ }^{150}$ Chin and Quadir posited that the traditional ways of looking at development is 'insufficient' for understanding the dynamics surrounding these new development actors. ${ }^{151}$ Therefore, for emerging donors, development cooperation is thought to be guided by the principles of South-South cooperation such as horizontality and equality, mutual benefit, non-intervention in domestic affairs, ownership, solidarity, and sovereignty. Individual Southern states also have South-South models of development. Brazil's model of development focus on technical cooperation and knowledge sharing on the basis of commonalities such as shared history, culture and language. Regional and geopolitical considerations are also strong motivators for development cooperation. According to Gore, South-South principles result in common tendencies that can be summarized as "bundling official assistance with trade and investment activities, tying aid to access to natural resources and/or purchase of provider goods and services, little or no policy conditionality (particularly around promoting liberalization, human rights, etc), focus on infrastructure and production, use of concessional loans even in poorer countries, stress on knowledge sharing, training and technology transfer over technical cooperation to make aid delivery happen smoothly."152 The South's foreign policy interests are couched in discourse that promotes "solidarity"

\footnotetext{
${ }^{150}$ Richey, Lisa Ann and Ponte, Stefano (2014). "New Actors and Alliances in Development." Third World Quarterly, 35(1).

${ }^{151}$ Chin and Quadir (2012), 495.

152 Gore (2013), 773-774.
} 
and "mutual benefit," 153 rather than "charity" and "benevolence." 154 In practice, Southern actors can be identified by their 'institutional independence' ${ }^{155}$ within the existing international aid system. They resist OECD-DAC principles, ${ }^{156}$ promote the idea that South-South cooperation is an alternative development model, ${ }^{157}$ and accept the legitimacy of a small group of middle-income countries as the representative leaders of the South within multilateral organizations.

Regional powers such as Brazil have acted as spokespersons for the Global South through criticism of the established international system of governance and have mounted efforts to reform the system through negation and reform. Vieira and Alden (2011) described the reaffirmation of the Global South's sense of solidarity as being politicized outwardly through rhetoric, policy positioning within multilateral forums and institutions, and new forms of resistance. ${ }^{158}$ Dreher et al. (2010) conducted a multi-country project on 16 new donors through statistical modeling (Probite and Tobit) between 2001 and 2008 and found that new donors (including Brazil) exhibited the following five characteristics: “(a) focus on closer neighbors, (b) care less for recipient need, (c) exhibit a weaker bias towards badly governed countries, (d) respond to disasters, but with fewer resources than old donors, and (e) do not pursue commercial self-interest [at a greater rate than

\footnotetext{
153 Robledo (2015).

${ }^{154}$ Mawdsley (2011).

155 Burges (2012), 233.

156 de Renzio and Seifert (2014).

${ }^{157}$ Quadir (2013).

${ }^{158}$ Vieira and Alden (2011), 510-511
} 
traditional donors]."159 Taken together, these characteristics seem to explain emerging donors engagement in development cooperation as a reflection of their capabilities, practices that are highly questionable (at least in theory), and in ways that support their national interests. These authors stated that "[f]or most new donors, any greater familiarity with recipient need does not translate into needs-based targeting."160 This finding does not support what is commonly understood to be a benefit South-South cooperation. A limitation of the study is that it did not include the key development providers of China and India. Studies such as those by Dreher et al. (2010) showcased the discrepancies surrounding the implementation of development cooperation and draws a parallel with the criticisms the South levy against the North. ${ }^{161}$

Discourse on the Emerging Donor Challenge

The writings of a number of scholars and practitioners of South-South cooperation and development cooperation consider emerging donors a challenge to the international aid architecture including Burges (2012), de Renzio and Seifert (2014), Fues (2013), Mawdsley (2011), Six (2009), and Woods (2008). The challenge emerging donors pose is that they operate outside the existing DAC driven international aid architecture. ${ }^{162}$ Southern-bred multilateral forums that exclude the North such as the

\footnotetext{
${ }^{159}$ Dreher, et al. (2010) np given, within 'Abstract.'

${ }^{160}$ Dreher, et al. (2010). 15.

${ }^{161}$ Dreher, et al. (2010).

162 Burges (2012); Abdenur and da Fonseca (2013).
} 
India, Brazil, and South Africa (IBSA), BRICS and G20 initiatives (BRICS Development Bank) have begun to recognize the benefit of policy dialogue among themselves. ${ }^{163}$ They are considered a threat because they bring attention to the inadequacies of the international aid architecture by representing the needs of the South in an inclusive way. ${ }^{164}$

The Southern brand of development cooperation brings to the traditional DACdriven international aid architecture contrasting norms and practices. ${ }^{165}$ At the global level, Southern donors do not have the incentive to report to traditional global institutions or to adhere to the reporting standards of DAC donors. ${ }^{166}$ Whether as a collective unit or individual state, emerging donor countries have not been forced to adhere to norms and practices of the North. Thus, the extent of this challenge to the traditional aid architecture is contested in the field of international development cooperation. In the following section, I examine the different perspectives authors hold regarding the influence of the emergence of emerging donors with their style of development cooperation and practices.

\footnotetext{
${ }^{163}$ Fues, Thomas (2013). "New Dynamics in South-South Cooperation.” German Development Institute. (DIE).

${ }^{164}$ See Abdenur and da Fonseca (2013); Gray, Kevin and Gills, Barry K. (2016). "South-South Cooperation and the Rise of the Global South.” Third World Quarterly, 37(4): 557-574.

${ }^{165}$ Rowlands, Dane (2012). "Individual BRICS or a Collective Bloc? Convergence and Divergence amongst 'Emerging Donor' Nations.” Cambridge Review of International Affairs. 25(4).

${ }^{166}$ Sinha, Pranay and Hubbard, Michael (2012). "How Does the Existence of IATI shape the Dynamics of Emerging Donors under South-South Cooperation?." University of Birmingham, International Development Department. 2. Accessed on July 26, 2016. http://www.birmingham.ac.uk/Documents/college-social-sciences/government-society/idd/research/aiddata/chapter3.pdf.
} 
Quadir reported the possibility that Southern providers can create a "new aid paradigm" by focusing on the "strategic needs of partner countries" rather than "advancing the ideological interests of donor countries;" however, the author also concluded that emerging donors will not be able to fundamentally alter the existing framework without the provision of "more international aid and creation of a common vision for development among emerging donors."167 Chin and Quadir continued with the assertion that it is unclear whether the BRIC donors represent a "clear departure" from the practices of the North. ${ }^{168}$ This idea raises the question of whether it makes a difference for recipient countries that emerging donors are now an option for partnership. According to Burges (2012), emerging donors would not be considered a threat to the OECD-DAC if the standard is the delivery of "effective official development assistance." 169 Currently, emerging countries such as Brazil, China, and India continue to remain outside the DAC. Rowlands agreed with Quadir that emerging donors present the opportunity to create a new aid architecture that attends to their concerns; however, Rowlands extended Burges (2012) assertion that emerging donors are not a threat to the existing aid architecture with the rationale that the emerging donors are "too heterogeneous" to pose a "collective" challenge. ${ }^{170}$ Gore's contribution bridged that of Quadir, Chin and Quadir, and Rowlands with his assertion that that the traditional aid

\footnotetext{
${ }^{167}$ Quadir (2013). 321.

${ }^{168}$ Chin and Quadir (2012). 495.

169 Burges (2012). 226.

${ }^{170}$ Rowlands, (2012). 630.
} 
architecture is actually being replaced by a more representative development cooperation with considerations beyond aid, as well as a new development cooperation architecture. Six (2009) found that development cooperation and the development paradigm function differently for non-Western donors (mainly from the Global South) because they do not have the same relationship with "colonial and postcolonial relations" as the Western donors. Non-Western donors "do not use historicist development rhetoric to legitimise their interventions[...] and for historical reasons cannot apply the same pseudoemancipatory rhetoric as Western development paradigm does." 171 This logic suggests that Southern donors' development cooperation and practices do not necessarily translate into development outcomes that are better for their recipients. Six asserted that development and the development cooperation paradigm is altogether questionable as a construct for non-Western donors. He characterized China's development cooperation in Africa as an example of "Realpolitik" and that the Chinese development paradigm presents "new programmes" and paradigms of "world development."172 The notion of world development adds another dimension to the discussion on the challenge emerging donors present to the current international aid architecture.

All of these cited scholars supported the idea that the existence of active Southern donors bring with them a qualitative difference that challenges the traditional DAC dominated international aid architecture. Yet, with the exception of Six, these researchers did not find Southern development cooperation sufficient to replace or

\footnotetext{
${ }^{171}$ Six, Clemons (2009). The Rise of Postcolonial States as Donors: A Challenge to the Development Paradigm?. Third World Quarterly, 30(6): 1108-1109.

${ }^{172}$ Ibid. 1115 .
} 
significantly alter what currently exist. Six's work tackles the issue of the incompatibility of the historical experience of non-Western states with the West. As the non-Western states and the ones upon whom development was done during the colonial and postcolonial past, they call into question the concept of development of cooperation and the development paradigm as a whole. Rather than assert that Southern donors have the potential to act similarly to traditional donors, they could be acting out of their own experiences. Six not only offered an alternative way of looking at the challenge Southern donors present to the international aid architecture, but also added to the rhetoric of solidarity and mutual benefits commonly found in Southern donor rhetoric.

\section{SOUTH-SOUTH COOPERATION IN LATIN AMERICA}

Latin American countries share the same basic principles of South-South cooperation as other Southern countries that includes a discourse on solidarity. ${ }^{173}$ These countries use development cooperation in a way that serves foreign policy interests. ${ }^{174}$ Robledo credited the implementation of the import-substitution industrialization model of the 1950 s as the starting point for Latin American cooperation and the ideological positioning against foreign intervention. By the 1970s, some countries became involved with Technical Cooperation among Developing Countries (TCDC). ${ }^{175}$ Generally

\footnotetext{
${ }^{173}$ Robledo, Carmen (2015). "New donors, Same Old Practices? South-South Cooperation of Latin American Emerging Donors." Bandung: Journal of the Global South, 2(3).

${ }^{174}$ Christensen, Steen Fryba (2013). "Brazil's Foreign Policy Priorities," Third World Quarterly, 34(2), 271-286; Dauvergne and Farias (2012); de Freitas Santos, Roberta and Cerqueira, Mateus Rodrigues (2015). "South-South Cooperation: Brazilian Experiences in South America and Africa." História, Ciências, Saúde - Manguinhos, 22(1); Inoue and Costa Vaz, 2012.

${ }^{175}$ Sanahuja, José Antonio (2010). "Post-liberal regionalism: S-S Cooperation in Latin America and the Caribbean in South-South Cooperation? The Same Old Game or a New Paradigm?," in "South-South
} 
speaking, South-South cooperation has been used by the region as a mechanism to achieve development in Latin America and represents a modality that is broad and diverse. For example, South-South cooperation has been used as a means to achieve Millennium Development Goals and as a regional development platform to tackle social inequality, weak institutions, and poverty. ${ }^{176}$ Robledo identifies the following SouthSouth cooperation principles as the ones that guide Latin American development cooperation (see Table 7).

Table 7

Principles of South-South Cooperation that Guide Latin American Development Cooperation

\begin{tabular}{|c|c|}
\hline South-South principles/schemes used & Examples \\
\hline Regional integration & $\begin{array}{l}\text { Mesoamerica Project, ALBA, MERCOSUR } \\
\text { [or Mercado Comun do Sul (Portuguese)], } \\
\text { UNASUR }\end{array}$ \\
\hline $\begin{array}{l}\text { Self-reaffirmation through good } \\
\text { citizenship and provision of global } \\
\text { goods }\end{array}$ & $\begin{array}{l}\text { Global governance sharing-Chile } \\
\text { Image \& global leadership around fighting } \\
\text { organized crime and governance building- } \\
\text { Colombia }\end{array}$ \\
\hline $\begin{array}{l}\text { Strengthen their regional and global } \\
\text { leadership }\end{array}$ & $\begin{array}{l}\text { Foreign policy tool and platform -Brazil } \\
\text { Petro-cooperation-Venezuela }\end{array}$ \\
\hline $\begin{array}{l}\text { Reduce economic dependency \& } \\
\text { consolidate their autonomy }\end{array}$ & $\begin{array}{l}\text { Technical assistance/training in exchange for } \\
\text { resources/technology-Cuba }\end{array}$ \\
\hline $\begin{array}{l}\text { Non-alignment through alternative } \\
\text { initiatives }\end{array}$ & $\begin{array}{l}\text { Proyecto Mesoamerica, the Mexico-Chile } \\
\text { fund, } \\
\text { Banco do Sul, the IBSA fund, BRICS bank }\end{array}$ \\
\hline
\end{tabular}

Cooperation? The Same Old Game or a New Paradigm?." Poverty in Focus edited by Rathin Roy and Melissa Andrade, International Policy Centre for Inclusive Growth, Bureau for Development Policy, UNDP, 25: 17-19.

${ }^{176}$ Betancourt, María Clara Sanín and Schultz, Nils-Sjard (2009). "South-South Cooperation in Latina America and the Caribbean: Ways ahead following Accra." FRIDE. March 2009, 2. 
Leverage in international organizations \& foster international coalitions

Self-legitimization
Undermine Western dominance- IBSA Global aspiration \& reform- Brazil seeking permanent seat on the UN Security Council View development cooperation not as traditional aid but a developmental approach

Source: Robledo, Carmen (2015). "New donors, Same Old Practices? South-South Cooperation of Latin American Emerging Donors." Bandung: Journal of the Global South, 2(3), 1-16.

Xalma (2013) presented major trends on South-South cooperation between 2007 and

2011 in Ibero America (including Spain and Portugal):

Despite a downward trend over the time-period studied, there is an average of 800 South-South cooperation projects in the region. Not every country reported findings for each year which is a reflection of the overall weakness of South-South cooperation recordkeeping. ie. Venezuela who provided $20 \%$ of total for 2009 however did not report for 2010 . Six countries (Argentina, Brazil, Chile, Colombia, Cuba and Mexico) tend to represent $95 \%$ of the 'bilateral horizontal SouthSouth cooperation' projects and the top six recipients (primarily Paraguay, and the Andean and Central American nations) account for less than $40 \%$ of the total projects received. ${ }^{177}$

These trends indicate that the region is dominated by six development providers and that $60 \%$ of the time, these donors engage in bilateral projects with a recipient country who is not one of the top recipients.

\footnotetext{
177 Xalma, Cristina. (2013). "The New Boom in South-South Cooperation: The Experience of IberoAmerica." Institute for the Integration of Latin America and the Caribbean @ Journal. January-June 2013,(36)17: 29-30.
} 
Muhr (2016) cited South-South cooperation as a function of the "interventionism" of "left-leaning" Latin America and Caribbean governments (Argentina, Brazil, Cuba, Ecuador, Uruguay, Bolivia) and the pursuit South-South cooperation as "Third World emancipation and liberation." ${ }^{178}$ Muhr argued that Latin American and Caribbean countries have shifted the South-South cooperation focus from the international or multilateral level to the regional level through "regionalisms;" the creation of regional projects like the Bolivarian Alliance for the Peoples of Our America - Peoples' Trade Agreement (ALBA-TCP) and sub-regionalist initiatives Petrocaribe, the Caribbean Community (CARICOM), the Common Market of the South (MERCOSUR), and the Union of South American Nations (UNASUR). ${ }^{179}$ Due to the number and level of regional and subregional multilateral fora, regionalism is regarded as a major cornerstone for Latin American development. ${ }^{180}$

Despite commonalities found in the region, there exist two distinct approaches to the leadership strategies by the regional forerunners Brazil led by President Lula and Venezuela under President Chavez. ${ }^{181}$ Both countries offer countries in the region opportunities to collaborate; however, Venezuela does so through a "statist path" for the benefit of a unique brand of socialist development, whereas Brazil offers a "marketfriendly" use of national firms. ${ }^{182}$ Specifically, Venezuela employs an "ODA-driven

\footnotetext{
${ }^{178}$ Muhr, Thomas (2016). "Beyond 'BRICS': Ten Theses on South-South Cooperation in the TwentyFirst Century." Third World Quarterly, 37(4): 630.

${ }^{179}$ Ibid.

${ }^{180}$ UNDP (2011).

${ }^{181}$ Burges (2007).

.$^{182}$ Ibid, 1344.
} 
foreign policy" premised on the distribution of the country's oil where the delivery of "rents" helps gain and strengthen its partnerships in the region, and Brazil seeks to create conditions that are beneficial for its domestic actors first "that might also be attractive to key constituencies in partner countries." 183 Both countries engage in bi-lateral and regional development assistance; however, Brazil's approach "requires active engagement with the global system"184 and has done so through what Hirst (2010) described as "enhanced" multilateral initiatives, particularly through the UN system since the 1990s. ${ }^{185}$

For example, Brazil was the first country to contribute to the Haiti Reconstruction Fund, a multi-country, multi-donor fund in the amount of USD $\$ 55$ million $^{186}$ and second behind the United States at USD $\$ 125$ million in the amount of dollars donated as reported by the HRF. ${ }^{187}$ The main idea behind the fund is to support the Government of Haiti's “Action Plan for the Recovery and Development of Haiti” and under the Haiti's leadership with a pool of bilateral and multilateral donors for receipt and delivery of resources in the areas of post-earthquake recovery, reconstruction, and development. The fund also includes participation with multilateral partner entities who are the Inter-

\footnotetext{
${ }^{183}$ Ibid. 1348-1349.

${ }^{184}$ Burges (2007).

${ }^{185}$ Hirst, Monica (February 2010). "Brazil in Haiti: the Challenges Ahead.” Norwegian Peacebuilding Resource Center.

${ }^{186}$ Reuters (May 2010). "Brazil Pays First Donation into Haiti Quake Fund.” Haiti Reconstruction Fund, May 11, 2010. Accessed December 16, 2017. http://www.haitireconstructionfund.org/news0511.

${ }^{187}$ Haiti Reconstruction Fund (2016). "Pledging Donors,” Accessed October 16, 2016. http://www.haitireconstructionfund.org/members.
} 
American Bank, the United Nations, and the International Finance Cooperation (IFC) of the World Bank.

In contrast, Chavez's foreign policy rhetoric heavily criticizes multilateral financial institutions and threatened to withdraw from all World Bank and the International Monetary Fund (IMF) agreements in 2007. Like Brazil, Venezuela also provided development cooperation for Haiti after the 2010 earthquake through a fund. The fund was operated under the umbrella of the regionally based Bolivarian Alliance for the Peoples of Our America - Peoples' Trade Treaty (ALBA-TCP)-Haiti (ALBA-TCPHaiti). As a part of the ALBA-TCP-Haiti, the Haiti-Cuba-Venezuela Tripartite Commission along with Ecuador and Nicaragua worked with the Haitian government to create the Alliance for Haiti. The Alliance for Haiti served as the project for the reconstruction of Haiti under the "Plan for the Solidarian [sic] Contribution of the ALBA Countries to the Effort of Reconstructing Haiti" action plan which the ALBA Bank funded through the "ALBA Humanitarian Fund for Haiti." 188 Despite the fact that Cuba and Venezuela were the only "material" contributors to the ALBA-TCP-Haiti initiative, they considered it a "collective" action. ${ }^{189}$ Table 8 below illustrates the institutional process and outcome for carrying out this action.

Table 8

\footnotetext{
${ }^{188}$ Amar, Paul (2012). Global South to the Rescue: Emerging Humanitarian Superpowers and Globalizing Rescue Industries. New York: Routledge, 153.

189 Ibid.
} 
Bolivarian Alliance for the Peoples of Our America - Peoples' Trade Treaty (ALBATCP)-Haiti Institutional Process and Outcome

\begin{tabular}{ll}
\hline Institutional Process & Result \\
\hline Framework & ALBA-TCP-HAITI \\
Commission & Haiti-Cuba-Venezuela Tripartite Commission \\
Coordinating Body & ALBA National Coordination \\
Establishment of Fund & ALBA Humanitarian Fund for Haiti funded by the ALBA \\
& Bank \\
Project & Alliance for Haiti \\
Plan & Plan for the Solidarian Contribution of the ALBA \\
\hline
\end{tabular}

Information compiled from Paul Amar (2013). Global South to the Rescue: Emerging Humanitarian

Superpowers and Globalizing Rescue Industries. New York: Routledge, 153-154.

At each point, the partner countries of ALBA with the Haitian government had control over the receipt, delivery or disbursement of funds, services and in-kind donations.

\section{Latin American Approaches to Haiti}

The work of Heine and Thompson (2011) provided a context for approaching Haiti on the matter of Latin American involvement in the only low-income country in the region. ${ }^{190}$ Heine and Thompson reported that Haiti as a state in the international system and the region of Latin America and the Caribbean is no longer an "outlier"191 for study based on a historically rooted "social formation." 192 Instead, they proposed that Haiti, as a country, engenders an "altogether different unit of analysis." 193 The study of Haiti did

\footnotetext{
${ }^{190}$ Heine, Jorge and Thompson, Andrew S (2011). Fixing Haiti: MINUSTAH and Beyond. New York: United Nations University Press.

${ }^{191}$ Ibid. 8.

192 Ibid. 4.

193 Ibid. 4.
} 
not become a serious subject of study for political scientists and economists until the concept of the failing, failed, and fragile state became a concept in 1990s. ${ }^{194}$

The rise in the study of failed states as an area of study by scholars coincided with the end of the Cold War and a largely democratic Latin America. It was at this point that countries in the region were willing to engage their militaries in peacekeeping operations through the UN including ten different countries around the world. ${ }^{195}$ An ideological shift occurred when some Latin American countries began to join the UN peacekeeping operations in Haiti, thereby creating a new lens from which to study inter-American relations and the issue of what to do about failed states.

The Foreign Affairs articles by Cressweller (1971) Mintz (1995) were two seminal works providing additional insight on the idea of considering Haiti a failed state in the region and Latin American involvement in the country. ${ }^{196}$ It is not uncommon for scholars on South-South cooperation and development cooperation to acknowledge Haiti's unique distinction of being the first slave colony to establish its independence. Both Cresswller and Mintz acknowledged the relevance of Haiti’s historical experience but in a way that analyzes the perspective of its impact on the country's socio-political and economic conditions inside the country.

\footnotetext{
194 Ibid. 5.

195 Forman, Johanna Mendelson (2011). "Latin American Peacekeeping: A New Era of Regional Cooperation" in Fixing Haiti: MINUSTAH and Beyond edited by Jorge Heine and Andrew S. Thompson. New York: United Nations University Press.

${ }^{196}$ Mintz, Sidney W. (1995). Can Haiti Change? Foreign Affairs, January/February 1995 74(1); Crassweller, Robert (1971). "Darkness in Haiti." Foreign Affairs, January 1971 49(2).
} 
France's refusal to grant full diplomatic recognition (without indemnity) is an example of a punishment exerted on Haiti for liberating itself from white rule and seeking to establish itself in the international system on the basis of equality. ${ }^{197}$ Further, Mintz concluded that the resulting 'polity' that formed after the unification of the families of the former free people of color and the military after independence does not have a comparable context in France or the United States. Other historical experiences for consideration include the nexus between the Vodun religion and the power of the structures of the regime ${ }^{198}$ and the role of wageless familiar and cooperative forms of farm labor among the peasant class ${ }^{199}$ Mintz's analysis stressed that the failure to consider Haiti's historical experience leads to the possibility of plans that are de facto unworkable. At the time of Crassweller's writing, the Duvalier government was in power and offered that the United States should avoid deep engagement in Haitian affairs, but instead called for a multilateral approach. ${ }^{200}$ Mintz wrote nearly 25 years later that North American countries default to inattention when it comes to its engagement with Haiti; however, the U.S. intervention on the island in 1915 has served to "confirm, sustain, and underwrite" the asymmetry already present within Haitian society following the independence with their military-based occupation. ${ }^{201}$ During the 21 st century, there was a multilateral non-U.S.-led peacekeeping operation approach to Haitian political crisis.

\footnotetext{
${ }^{197}$ Mintz (1995).

198 Crassweller (1971)

${ }^{199}$ Mintz (1995)

${ }^{200}$ Crassweller (1971), 328.

${ }^{201}$ Mintz (1995), 86.
} 
The works of Crassweller and Mintz provided a socio-political and economic perspective on Haiti by suggesting that the country's historical experiences that occurred as a result of gaining its independence from France should be taken into consideration when making plans and developing solutions on Haiti's behalf. The logic of all three authors was that Haiti as a state should be approached differently by providers of development (North or South) because of the country's historical experiences within the international system. Prior to 2004, the main international actors in Haiti were the United States, France, and Canada. Following the political crises and ouster of President Aristide, the United Nations Security Council authorized the deployment of a U.S.-led Multinational Interim Force comprised of forces from Canada, Chile, France, and the United States for a period of three months to help secure the capital city of Port-au-Prince. In February, Brazil voted for Resolution 1529 creating the interim force; however, Brazil did not join the deployment of troops. ${ }^{202}$ In April 2004, UN Security Council passed UN Resolution 1542 transferring the authority of the Multinational Interim Force to the UN Stabilization Mission in Haiti (MINUSTAH) led by Brazil and mainly Latin America forces and police from Argentina, Brazil, and Chile who are commonly referred to as the "ABC" countries. Chapter VII of the UN Charter grants MINUSTAH to act on behalf of peace, security, and human rights for the purpose securing a stable environment in Haiti; however, it also authorizes the use of force.

\footnotetext{
${ }^{202}$ Ekström, Karin and Alles, Leonardo (2012). "Brazilian Foreign Policy Under Lula: From Nonintervention to Non-indifference.” Political Perspectives, 6(2), 9-29; Hirst (2010).
} 
ABC countries involvement in MUNUSTAH reflected each of their individual country's "foreign policies and international interests."203 Feldman, Lengyel, Malacalza, and Ramalho (2011) argues that the ABC countries missed an opportunity to utilize their participation in MUNUSTAH as a platform to display their international development cooperation programs and South-South cooperation activities in Haiti. ${ }^{204} \mathrm{ABC}$ countries engagement in UN peacekeeping activities in Haiti marked an ideological change in Inter-American relations.

Between February 2004 and April 2004, Brazil shifted away from its constitutional principle of non-intervention and embraced the principle of inindifference ${ }^{205}$ when it agreed to join peacekeeping operations in Haiti. According to Ekström and Alles, "non-indifference is a selective incorporation of assumptions concerning preexisting analytical frameworks adapted to Brazilian needs." 206 Brazil had taken on the demeanor of the superpowers during the Cold War years who "didn't hesitate to intervene either directly or indirectly in the countries of their respective spheres of influence."207

\footnotetext{
${ }^{203}$ Perales, José Raúl (2011). "Haiti and the Regional Dynamics of International Cooperation" in Fixing Haiti: MINUSTAH and Beyond edited by Jorge Heine and Andrew S. Thompson. New York: United Nations University Press, 180.

${ }^{204}$ Feldman, Andreas, Lengyel, Miguel, Malacalza, Bernabé and Rmalho, Antonio (2011). "Lost in Translation: ABC Cooperation and Reconstruction in Haiti." Journal of Peacebuilding and Development, 6(3): 1- 17; Special Issue, Washington, DC, United States: Center for Global Peace, American University.

${ }^{205}$ According to Brazil's former minister of foreign relations Celso Amorim, the principle of nonindifference was a new interpretation of the principle of non-intervention.

${ }^{206}$ Ekström and Alles, (2012), 12.

${ }^{207}$ Ibid, 11.
} 
Ekström and Alles wrote that President Lula received a call from the French President Jacques Chirac requesting Brazil to assume leadership of MINUSTAH (although Brazil had already committed to a future U.S.-led peace keeping operation in Afghanistan and Iraq). ${ }^{208}$ Brazil's shift in foreign policy around non-intervention is attributable to its interpretation of Chapter VII of the category of 'peace enforcement to peacekeeping. ${ }^{209}$ Brazilian engagement in MINUSTAH is tied to its quest for candidacy to a permanent seat on the UN Security Council. ${ }^{210}$

Bernabé Malacalza (2014) identified three models of international cooperation in Haiti after the 2010 earthquake. ${ }^{211}$ The three models or approaches to Haiti are as follows: (a) public and business diplomacy model (the U.S. is the main actor); (b) the alternative solidarity politicization model (mainly aligned with Venezuela and the ALBA countries); and (c) the neo-developmentalist diplomacy model (the ABC countries led by Brazil). ${ }^{212}$ According to Malacalza, after 2004, the United States began to "outsource" the role of military intervention and took the position of restructuring and diversifying its presence in Haiti in the areas of trade, investment, humanitarian aid, logistical support, security cooperation, institutions, electoral monitoring, environmental protection, etc. ${ }^{213}$

\footnotetext{
208 Ibid. 17-18.

209 Ibid. 18.

${ }^{210}$ Ibid.; Nieto (2012), 166-169.

${ }^{211}$ Malacalza, Bernabé (2014). “Modelos de Cooperación Internacional para el Desarrollo en Haití. Discursos, Prácticas y Tensiones.” Relaciones Internacionales, Mayo 2014, Número 25.

212 Ibid.

213 Ibid. 58.
} 
Additionally, Malacalza cited the personal impressions of Hillary and Bill Clinton for contributing to greater activism in public policy in defense of Haiti. ${ }^{214}$ Following the earthquake, the author noted that The United States Agency for International Development (USAID) pursued a strategy to counteract state weakness in through an intersection of defense, development, and diplomacy. ${ }^{215}$ Both the United States and the European Union used Haiti as "pilot case" case for policy assistance in fragile state. ${ }^{216}$ Though the States sought to have a dominant presence in Haiti following the 2010 earthquake, it was the Clinton Global Initiative with the more dominant presence with MINUSTAH and the advisors and operators for private investment in the country. ${ }^{217}$ Between 2010 and 2013, the decentralized process of program implementation in the United States incentivized NGO participation in development cooperation that by passed the Haitian government. ${ }^{218}$ Overall, the U.S. model is articulated through the U.S. State Department, USAID, private investments, and contractors, with special note given to the USAID contractor in Haiti Chemonics International. ${ }^{219}$

The alternative solidarity politicization model is rooted in the "Venezuela-Haiti political nexus" dating back to Latin American independence. ${ }^{220}$ Venezuela, Cuba, and

\footnotetext{
214 Ibid.

215 Ibid. 59.

${ }^{216}$ Ibid.

217 Ibid. 60.

${ }^{218}$ Ibid. 61.

${ }^{219}$ Ibid. 61

${ }^{220}$ Ibid. 62.
} 
Mexico did not participate in MINUSTAH. Chavez worked directly with then Haitian president Rene Preval to provide PetroCaribe funded initiatives around energy and oil. ${ }^{221}$ Chavez espoused a strong rhetoric on the importance of supporting Haiti because he viewed the Island as a victim of capitalism and imperialism and deserving of Venezuela's assistance due to their historical linkages. After the 2010 earthquake, Venezuela "amplified" its efforts to include actions through Bolivarian Alliance for the Peoples of Our America (ALBA). ${ }^{222}$ Venezuela provides direct budgetary supports to partner country governments, which distinguishes their approach from other models. ${ }^{223}$ Between 2010 and 2013, it is estimated that USD\$1,007,288, 456 has been transferred to Haiti from Petrocaribe. ${ }^{224}$

The neo-developmentalist diplomacy model follows from the Lula's decision to lead MINUSTAH in 2004. ${ }^{225}$ Lula "acknowledged development thinking" in their approach to Haiti including public investment, development, energy, transportation, telecommunications and housing construction as the basis. ${ }^{226}$ Malacalza attributed the model mainly to Brazil over Argentina and Chile because Haiti is a priority in Brazil's foreign policy. ${ }^{227}$ According to Abdenur and de Souza Neto (2014), Brazil has been

\footnotetext{
${ }^{221}$ Ibid. 62.

${ }^{222}$ Ibid. 63.

${ }^{223}$ Ibid.

${ }^{224}$ Ibid. 64.

${ }^{225}$ Ibid. 66.

${ }^{226}$ Ibid. 66-67.

${ }^{227}$ Ibid. 67.
} 
criticized for "securitization of development," which means bringing together security and development in a way that legitimizing its "security pursuits" rather than "socioeconomic development."228

\section{CONCLUSION}

This study grounded the idea of South-South cooperation as an alternative development strategy for developing countries in the Global South through an explanatory framework. Through this explanatory framework-based literature review, I offered a way to work with and contextualize the relationship between South-South cooperation and development cooperation to better understand the potential of the SouthSouth cooperation framework and reasoning for the main hypothesis that South-South cooperation effects development cooperation to the extent that the SSC framework can strengthen, weaken or have no impact on development on the study's case countries. Through this literature-based explanatory framework, I emphasized the intersectionality of past, present, and future when addressing contemporary development cooperation between Southern countries.

\footnotetext{
228 Abdenur, Adriana. Erthal and De Souza Neto, Danilo Marcondes (2014). "Rising Powers and the Security-Development Nexus: Brazil's Engagement with Guinea-Bissau", Journal of Peacebuilding \& Development, 9(2): 1-16.
} 


\section{CHAPTER 3}

\section{METHODOLOGY}

\section{INTRODUCTION}

This research study originated from the understanding that Brazil and Haiti's antithetical development positions serve as the foundation for interrogating the nature of South-South cooperation as an alternative development strategy. In this study, I employed a qualitative, non-experimental research design to explain the rationale for Brazil's collaboration with Haiti through an exploration of the benefits, challenges, and strategic rationale for the application of SSC framework between the two countries. The selection of qualitative research approach was appropriate because of the exploratory nature of the study. ${ }^{229}$ Consistent with the qualitative research framework, the purpose of the study was to examine the overall cooperation framework between Southern countries through answering the central question of, "Why Southern countries engage in SouthSouth cooperation?" through the Brazil-Haiti case. The endeavor of uncovering the underlying reasons or motivations for the existence of a complex, contemporary phenomenon within a particular context is qualitative in nature. The results of quantitative data are often based on numbers that reflect the strength or weakness of the relationship of two or more variables. ${ }^{230}$ The quantitative research method would not be able to provide the same data needed to explain the central phenomenon South-South

\footnotetext{
${ }^{229}$ Marshall, Catherine, and Rossman, Gretchen B. (2014). Designing Qualitative Research. Thousand Oaks, CA: Sage.

${ }^{230}$ Crassweller (2013).
} 
cooperation when Southern actors do not follow systematic reporting mechanism to evaluate and assess outcomes on development.

The specific research design that I used was multiple case study. Since context is a part of the research design, there would be too many variables to control when considering the phenomenon of South-South cooperation. ${ }^{231}$ The selection of two countries in a single region from two highly divergent development positions allowed for research on MIC and LIC without cross-regional considerations. China is the remaining BRIC from the Global South that offers the possibility of a MIC-LIC pairing (with Cambodia, North Korea, or Nepal), similar to that of Brazil and Haiti. Overall, the objective of the study was to examine the rationale for Southern countries engagement in South-South cooperation through the case of Brazil and Haiti. Thus, I sought to capture the professional, diplomatic, and political experiences of high-ranking officials, leaders, and experts on South-South cooperation and Latin American and Caribbean relations.

In Chapter 3, I will detail the key aspects of the data collection process and data analysis, including the methodology employed to identify patterns located in the data that served as the basis for the political analysis put forward in the concluding chapter.

\section{DATA COLLECTION}

In qualitative studies, the researcher acts as the main instrument in the collection and analysis of data. ${ }^{232}$ As the main instrument of the research, I was responsible for

\footnotetext{
231 Yin (2014).

${ }^{232}$ Malagon-Maldonado, Gabriella (2014). “Qualitative Research in Health Design.” HERD: Health Environments Research \& Design Journal, 7(4).
} 
recruiting participants, collecting data, and generating findings through data analysis. For the semi-structured interviews and survey questionnaires, I attempted to create a participant pool with adequate representation from both case countries so that the ideas and sentiments of South-South cooperation would be balanced and representative of the provider and recipient perspectives. For the open-ended surveys, I gave participants the option of a phone-in or an e-mail version of the survey questions in the language of their choosing (Spanish, English, or French). I provided this option for those with English as a second language who felt that speaking would better convey the intent of their answers than writing outside their native language. One non-English speaking participant responded to the survey-questionnaire provided to him in Spanish. For the collection of documents, I searched for as many relevant documents available online in order to complement the data from the semi-structured interviews and the open-ended surveys.

As previously mentioned, the population for the study included current and former leaders, government officials, advisors, consultants, and political appointees of Haiti and Brazil who have professional experience or knowledge of South-South cooperation and scholar-practitioners on Latin America, Brazil, and Haiti. Additionally, the participant pool included individuals from the World Bank and the U.S. government. The first group of participants completed individual semi-structured interviews and the second open-ended surveys. The total sample size for the study was 16 participants. Table 9 below provides information about the demographic backgrounds and expertise of the participant pool. 
Table 9

Participant Demographic

\begin{tabular}{ll}
\hline Participant & Credential/Position \\
\hline Participant 1 & High-level advisor to the Haitian government \\
Participant 2 & Former high-ranking Haitian official and political appointee \\
Participant 3 & High-ranking Haitian government official and elected official \\
Participant 4 & High-ranking Brazilian government official and career diplomat \\
Participant 5 & Scholar-practitioner and Latin Americanist \\
Participant 6 & High-ranking official with the U.S. government \\
Participant 7 & A monitoring and evaluation specialist and contractor with USAID \\
Participant 8 & Scholar-practitioner on international development \\
Participant 9 & Latin-Americanist scholar \\
Participant 10 & Scholar-practitioner on Brazil \\
Participant 11 & Brazilianist scholar \\
Participant 12 & World Bank development and disaster relief specialist and scholar- \\
& practitioner \\
Participant 13 & High-ranking Haitian government official and career diplomat \\
Participant 14 & Scholar on development and security* \\
Participant 15 & Scholar-practitioner on Haiti \\
Participant 16 & High-level consultant to the Haitian government \\
\hline
\end{tabular}

* Recommended a document in lieu of directly answering survey-questionnaire.

The adequacy of sample size in qualitative studies is often assessed using the concept of data saturation, which is the point in which the data no longer produce new information that has not been uncovered in the earlier participants. ${ }^{233}$ Although data saturation is not fixed for every study and can be different every time, scholars have generally indicated that data saturation can occur as early as six participants. ${ }^{234}$ During the course of this study, data saturation was achieved by adding survey questionnaire respondents to the participant pool.

\footnotetext{
${ }^{233}$ Francis, Jill J., Johnston, Marie, Robertson, Clare, Glidewell, Liz, Entwistle, Vikki Ann Eccles, Martin P. and Grimshaw, Jeremy M. (2010). "What is an Adequate Sample Size? Operationalising Data Saturation for Theory-based Interview Studies." Psychology and Health, 25(10): 1229-1245.

${ }^{234}$ Guest, Greg, Bunce, Arwen and Johnson, Laura (2006). "How Many Interviews are Enough? An Experiment with Data Saturation and Variability." Field Methods, 18(1).
} 
I collected the study's data using an explanatory framework of literature, semistructured interviews, open-ended surveys, and archival data sources. The rationale for using multiple sources of data was to generate findings that are comprehensive and indepth. 235Prior to the recruitment and collection of data, I submitted an online application to the university's Internal Review Board (IRB), which the IRB reviewed and deemed Exempt with no special conditions under 46.101 (b) (1) of the Florida International University Common Rule's Exempt Review process.

I was able to achieve IRB approval; however, I was unable to begin the recruitment and collection of data until approximately 1 year later, due to extenuating circumstances and the political and economic crises in both case countries during 2015 and most of 2016. Although the IRB deemed this study Exempt with no special conditions under 46.101 (b) (1) of the Florida International University Common Rule's Exempt Review process, I provided the interviewees and survey questionnaire participants a basic description of the study, copy of the IRB approval letter and contact information for the chair of the dissertation committee and myself as the researcher.

Data collection began with developing an explanatory framework on the phenomenon of South-South cooperation. This task required bringing together a variety of works that could frame the explanation of why Southern countries engage in SouthSouth cooperation. This included academic literature, materials, and reports from international and multilateral organizations, institutes, and conferences. I used findings from the literature review to fill in information on the phenomenon and context of South-

${ }^{235}$ Yin (2014). 
South cooperation that ensued from the findings of the interviews and survey questionnaires.

I scheduled the semi-structured interview discussions and dial-in surveyquestionnaires based on the availability and preference of each of the participants. I gave each recruited participant a specific due date in order to ensure that data collection could be completed by the project data collection end date (early October). I informed all participants before the start of the interviews and phone-surveys that the sessions would be digitally recorded. The delay in data collection directly impacted the direction of the project to include analysis on the influence of the political and economic crises the countries were embroiled on the phenomenon of South-South cooperation.

The use of multiple sources of data is aligned with the framew ork of case studies wherein various perspectives or tools are used in order to arrive with a comprehensive understanding of a phenomenon. ${ }^{236}$ The selection of a combination of officials, leaders, and subject matter specialists at the expert level for the purpose of accessing credible, authoritative data sources to strengthen the project's final conclusions. Interviews allows researchers an opportunity to gain more in-depth information on specific policies and initiatives, as well as a way of way to examine the "processes, motivations, and reasons for successes or failures." 237 I used primary resources such as newspapers, speeches, and validated government documents to provide context and fill the gaps in timelines presented by the participants. In this way, I utilized multiple data sources, which were

\footnotetext{
236 Yin (2014).

${ }^{237}$ Willis, K., 2006. “Chapter 15: Interviewing” in Doing Development Research. edited by Vandana Desai, and Robert B. Potter. London: Sage.
} 
thereby instrumental in the generation of a narrative that helped to explains the phenomenon of contemporary South-South cooperation.

\section{$\underline{\text { Semi-structured Interviews }}$}

Semi-structured interviews were the primary data collection sources for the study. Semi-structured interviews are used in qualitative studies to explore the perceptions or experiences of participants using a series of open-ended questions. ${ }^{238}$ Semi-structured interviews are different from structured interviews in terms of flexibility. I prepared an interview guide before the interview so that a set of open-ended questions could serve as the main framework of the data collection process. Consistent with the flexibility of semi-structured interviews, I asked follow-up and probing questions to further gain a deeper understanding of the responses of the participants. ${ }^{239}$ I grouped the questions thematically to encourage a coherent line of reasoning promoted by the order of the questions. The main task of the interviews was to provide information about why Brazil chooses to be in a bilateral cooperation with Haiti, and understand how the South-South cooperation framework is beneficial, challenging, and strategic to both Brazil and Haiti. The responses of the leaders and other key individuals in the study served as the foundation of the themes that I generated during the data analysis. These themes that were based on the analysis of the interview responses were instrumental in answering the central research question and the corresponding sub-questions.

\footnotetext{
${ }^{238}$ Galletta, Anne (2013). Mastering the Semi-Structured Interview and Beyond: From Research Design to Analysis and Publication. New York, NY: NYU Press.

${ }^{239}$ Ibid.
} 


\section{Open-ended Survey Questionnaires}

Open-ended survey questions served as another source of data for the study. Open-ended surveys involve the participation of individuals who are asked to answer questions in order to illuminate the diversity of the topic within a population. ${ }^{240}$ Gillham states that "open questions can lead to a greater level of discovery." 241 One of the main advantages of the survey questionnaire is the low cost and time involved in gaining greater participation rates over a short period of time. ${ }^{242}$ These factors serve as the main differences between individual interviews and open-ended survey questionnaires.

For the survey questionnaires, scholar-practitioners received seven questions from the interview guide that aligned with the main framework of the data collection process. The scholar-practitioners shared a common interest or characteristic around South-South cooperation, and the open-ended question format offered them the ability to provide insight and feedback based on their experience of the phenomenon. When participant preference became an issue around ability to express complex ideas in the written format, I offered the questionnaire on a dial-in basis. I transcribed the audio responses using the digital recording and typing into Microsoft Word. Otherwise, survey-questionnaire participants emailed their written responses at a date and time prior to the data collection project deadline.

\footnotetext{
${ }^{240}$ Gillham, Bill (2000). Developing a Questionnaire. London: Continuum.

${ }^{241}$ Ibid. 5

${ }^{242}$ Ibid.
} 


\section{$\underline{\text { Archival Data Sources }}$}

Archival data sources were the last set of materials used for this study, beginning at Brazil and Haiti's initial attempt at technical cooperation in 1982 through November 2016 and the confirmation of Haiti's elections and Brazilian presidential scandal around corruption. These documents included key government renderings though documents, manuals and statistics on Brazil-Haiti cooperation. Newspaper articles, official statements and press releases and academic writings provided additional background and context.

\section{Government Records}

Government records were an important source of official information and statistics on technical cooperation and South-South cooperation between Brazil and Haiti. The Brazilian Ministry of Foreign Relations generates extensive data on Brazil's SouthSouth cooperation between 2000 and 2014 through its Agência Brasileira de Cooperação $(\mathrm{ABC})$ website. This period highlights the rise and subsequent fall of Brazilian activism in technical cooperation including its exceptional years of engagement with Haiti beginning in 2004. Though searches of the Haitian government website did not produce the same level of data and information, its Ministry of Planning and External Cooperation provided valuable background on the history of planning and position on foreign cooperation. 


\section{Newspapers}

In this study, newspapers were an important source of historical information and account of contemporary events. The press as a source of socio-historical data has been used in social science research. ${ }^{243}$ Leading newspapers with national or international circulation from the case countries were selected to provide background, context and collaborative findings for the study: in Brazil Folha de S. Paulo (founded 1921) and $O$ Estado de São Paulo (founded 1875) and in Haiti Le Nouvelliste (founded 1898) and HaitiLibre. With the exception of HaitiLibre, each newspaper has been in circulation for 95 years or more. The South-Florida paper, the Miami Herald (founded 1903), also covers issues of importance to both case countries and offers the added benefit of U.S.Latin American relations.

I collected newspaper articles by accessing their online databases and conducting a combination of keyword issue area searches. I used data obtained from the key word searches to retrieve information and cross-reference, contextualize, and situate the interview and survey questionnaire findings of the respondents. Taken together, the newspaper articles offered a combination of hard facts, national and international sentiment, and information to fill in gaps in knowledge and understanding related to the main topics of the study.

\footnotetext{
${ }^{243}$ Franzosi, Roberto (1987). "The Press as a Source of Socio-Historical Data: Issues in the Methodology of Data Collection from Newspapers." Historical Methods: A Journal of Quantitative and Interdisciplinary History. 20(1): 5-6.
} 


\section{Speeches and Press Releases}

Speeches and press releases represent official sources and statements of policy and opinion. Speeches in particular offer the tenor and thinking of public officials. In this study, I accessed speeches and press releases from government websites and online newspaper databases. Speeches from Presidents Lula and Martelley figured prominently in the discourse on Brazil-Haiti relations, along with statements from other leading political officials including Brazil's Marco Aurelio Garcia and Celso Amorim. In addition, press releases by the Brazilian government announced news and hard facts on Brazil's engagement in Haiti. Speeches and press releases augment government records and newspaper findings on each case country.

\section{DATA ANALYSIS}

After I collected all the data, I transcribed all transcripts of the interviews discussion and open-ended survey questionnaire responses in Microsoft Word, and imported, stored and organized the transcripts in ATLAS.ti. I used ATLAS.ti qualitative software to support and facilitate data management, storage and analysis. I transferred all the archival data sources that were collected to the qualitative software for the data analysis.

I analyzed data using qualitative content analysis in order to generate themes central to the research phenomenon of exploring the benefits, challenges, and strategic rationale for the application of the SSC framework to Brazil and Haiti. Qualitative content analysis is the systematic examination of data in order to interpret their 
meaning. ${ }^{244}$ The specific procedure involved in the qualitative content analysis was the system created by Philip Mayring. ${ }^{245}$ Qualitative content analysis commenced with determining how many data points could be identified. ${ }^{246}$ This step entailed scanning the data for key words and phrases by reading all the data collected from the participants. ${ }^{247}$ After acquiring an understanding of the data, I assessed the direction of the analysis.

The next important step in the qualitative content analysis procedure is the inductive generation of categories through coding. ${ }^{248}$ The creation of categories and subcategories involved assigning labels to different portions of text based on their meaning. After generating the list of codes, I grouped the findings into themes and categories. For instance, the participants made multiple mentions of "military and security," and I noted the number of mentions with the assistance of ATLAS.ti. These categories were instrumental in the generation of themes central to the understanding of the benefits, challenges, and strategic rationale for the application of SSC framework to Brazil and Haiti. Using the previous example "military and security," I determined that "military and security" was a benefit that Haiti receives from the South-South cooperation. After analyzing all of the data, I also identified "social benefits" and "economic benefits" as

\footnotetext{
${ }^{244}$ Kohlbacher, Florian (January 2006). "The Use of Qualitative Content Analysis in Case Study Research." Forum Qualitative Sozialforschung/Forum: Qualitative Social Research, 7(1) Article 2, Accessed July 28, 2016. http://www.qualitative-research.net/index.php/fqs/article/view/75/153.

${ }^{245}$ Mayring, Philip (2014). Qualitative Content Analysis: Theoretical Foundation: Basic Procedures and Software Solution. Accessed July 22, 2016. http://nbn-resolving.de/urn:nbn:de:0168-ssoar-395173.

${ }^{246}$ Ibid.

${ }^{247}$ Ibid.

${ }^{248}$ Ibid.
} 
part of the "socioeconomic" benefits Haiti receives from South-South cooperation; hence, the codes "military and security" and "socioeconomic" were identified under the theme "benefits for Haiti," which addresses the first research sub-question. I handled and analyzed all of the gathered data from all of the data sources with the same procedure.

The final stage in the qualitative content analysis was the process of interpreting the findings. ${ }^{249}$ I analyzed the results of the coding process within the context of the research questions and the purpose of the study. The end result of the analysis was the creation of an explanation of the benefits, challenges and strategic rationale for the application of SSC framework to Brazil and Haiti. The narrative of the case study was based on the categories and the sub-categories that were developed from all the data collected in the study.

\section{LIMITATIONS}

Limitations pertain to aspects of the study that can be considered as weak or potentially problematic to the results ${ }^{250}$ The first limitation of the study was that the effectiveness of South-South cooperation cannot be determined because no experimentation or manipulation of independent variables were performed. I could not identify a cause-and-effect relationship because of the limitations of the selected case study research design. The research design mainly explained the benefits, challenges, and strategic plans of Haiti and Brazil in engaging in the South-South cooperation. Case

\footnotetext{
${ }^{249}$ Ibid.

${ }^{250}$ Baron, Mark A. (2008). Guidelines for Writing Research Proposals and Dissertations. Division of Educational Administration: University of South Dakota, 1-52.
} 
studies only focus on explaining or understanding how or why a phenomenon exists within a specific context. ${ }^{251}$

The second limitation of the study was that the case study was primarily based on the perceptions and experiences of leaders, officials, and scholar-practitioners on Haiti and Brazil. Failing to include the perceptions of other key stakeholders in South-South cooperation between Brazil and Haiti may have led to a less comprehensive understanding of the case study.

Lastly, the study was limited to Haiti and Brazil, two member countries of LAC that share some common cultural and historical affinities, however are not representative of the pairings of other LAC countries who would be categorized as strictly middle income. The study findings may not be generalized to other LAC countries or other countries in the Global South with significantly different political and cultural background or middle-income.

\section{OVERVIEW OF DATA AND ANALYSIS CHAPTERS}

In the second half of the dissertation, I will present the findings, discussion, and conclusion of the study. In order to understand and interpret the study's findings, I will present important historical factors in Brazil-Haiti relations.

251 Yin, (2014). 


\section{CHAPTER 4}

\section{$\underline{\text { A TWIN CASE OF EXCEPTIONALISM }}$}

\section{INTRODUCTION}

In this chapter, I will analyze the collaboration between Brazil and Haiti. As discussed in Chapter 1, I approached South-South cooperation as a strategy and a framework employed by Global South countries in the exploration of the benefits, challenges, and strategic rationale for the application of the SSC framework. The chapter opens with an analysis of the differences in application of crisis by the international community to Haiti and Brazil in order to contextualize the major themes and sub themes that emerged from the data collected. The chapter then covers the findings of the study in sub-sections according to the sub-questions of the research. The three sub-sections are: (a) benefits of engaging in the SSC framework, (b) challenges from engaging in the SSC framework, and (c) strategic plans for engaging in the SSC framework. Under each subsection, the themes and sub-themes are presented according to the number of mentions, in which the theme with the most number of mentions is presented first. Summative tables are provided after each sub-section. The chapter concludes with a summary of the chapter findings, addressing the role of crisis and the rise of Brazil as a development provider in the context of the participants' findings.

\section{CONTEXTUALIZING CRISIS - HAITI}

Beckett (2013) asked, "Is it possible to speak of Haiti without speaking of crisis?" and cited three ways crisis has been applied to Haiti: (a) crisis as a historical 
categorization of "decline rather than progress," (b) crisis as a political norm of the nation-state, and (c) crisis as diagnosis by foreign experts "that is used to justify repeated foreign invasion and intervention." ${ }^{252}$ According to Beckett, Haiti's social, political, and economic problems are rarely viewed as descriptive, but instead intrinsic to Haitian society. ${ }^{253}$ Further, Beckett argued that the problem of state weakness and failure in Haiti are more likely caused by political and economic relationships at the international level.

On the part of Haiti, in the years leading up to the first invasion—-between 1888 and 1915 - ten presidents failed to complete an entire term in office due to a combination of political assassinations, military coup d'état, and one death by natural causes. In December 1990, Jean Betrand Aristide became the first democratically elected president after a 186-year period of authoritarian rule in Haiti; however, Aristide was overthrown by military coup d'état in September 1991. Despite the successful election of President Aristide, the long-standing cycle of Haitian economic and political upheaval the use of foreign invasion and foreign intervention has continued to be the response of the international community throughout 21 st Century. Table 10 lists foreign invasions and foreign interventions into Haiti between 1914-present.

\footnotetext{
${ }^{252}$ Beckett (2013), 27.

${ }^{253}$ Ibid.
} 
Table 10

Foreign Invasions and Foreign Interventions into Haiti: 1914-present

\begin{tabular}{|c|c|}
\hline Year & Invasion/Intervention \\
\hline 1914 & $\begin{array}{l}\text { U.S. Marines sent to Haiti to remove } \$ 500,000 \text { from the Haitian National } \\
\text { Bank for "safekeeping." } 254\end{array}$ \\
\hline $1915-1932$ & $\begin{array}{l}\text { U.S. occupation of Haiti authorized by U.S. President Woodrow Wilson } \\
\text { with the deployment of the Marines }\end{array}$ \\
\hline 1990 & $\begin{array}{l}\text { United Nations Observer Group for the Verification of the Elections in } \\
\text { Haiti (ONUVEH) for the preparation and observation of elections }\end{array}$ \\
\hline 1993 & $\begin{array}{l}\text { United Nations Mission Civile Internationale en Haiti or MICIVIH civil } \\
\text { mission joint operation between the United Nations and the Organization } \\
\text { of American States (OAS) for the organization of the presidential } \\
\text { elections and promotion of human rights }\end{array}$ \\
\hline 1997 & $\begin{array}{l}\text { United Nations Transition Mission in Haiti or UNTMIH for the } \\
\text { professionalization of the Haitian National Police }\end{array}$ \\
\hline 1999 & $\begin{array}{l}\text { The United Nations Civilian Police Mission in Haiti or MIPONUH for the } \\
\text { professionalization of the Haitian National Police }\end{array}$ \\
\hline 1993-1996 & $\begin{array}{l}\text { United Nations Mission in Haiti or UNMIH to assist with stabilizing the } \\
\text { country, professionalizing the arm forces, the creation of a separate police } \\
\text { force and support of democratic elections }\end{array}$ \\
\hline 2004 & $\begin{array}{l}\text { United Nations authorized a 3-month Multinational Interim Force or MIF } \\
\text { composed of troops from the U.S., France, Chile and Canada }\end{array}$ \\
\hline $\begin{array}{l}\text { 2004- } \\
\text { present }\end{array}$ & $\begin{array}{l}\text { UN Stabilisation Mission in Haiti or MINUSTAH succeeded the MIF led by } \\
\text { a Brazilian force commander and troops mainly of the Latin America (Brazil, } \\
\text { Uruguay, Chile, Argentina). Brazil continues to lead the mission. }\end{array}$ \\
\hline
\end{tabular}

Source: United Nations Peacekeeping, "Peacekeeping Operations." (webpage access). Accessed January 4, 2017. http://www.un.org/en/peacekeeping/operations/

Some writers have considered the initial occupation of Haiti by the United States in 1915 (following their 1914 arrival) and subsequently others to be a violation of international law and departs from the notion of a country's right to self-determination. ${ }^{255}$ I would argue that the repetitive use of foreign invasion and foreign intervention by the

\footnotetext{
${ }^{254}$ United States Department of State; Office of the Historian "U.S. Invasion and Occupation of Haiti, 1915-34.” (Webpage). Accessed on February 21, 2017. https://history.state.gov/milestones/19141920/haiti

${ }^{255}$ Beckett (2013), 38.
} 
North (and South) as the prescription for resolving situations deemed crisis by the international community on behalf of Haiti breeds a combination of Haitian exceptionalism. It establishes support and maintains a norm that foreign invasion and foreign intervention are the natural course of action for addressing Haiti's problems. These actions in the eyes of the international community legitimately bypasses the Haitian government, the will of the Haitian people, as well as norms around sovereignty and right to determination applied to other countries.

Reisman (1995) discussed five criticisms of the UN Security Council Resolution 940, and called for the restoration of democracy and the return of President Aristide to power through intervention. A summary of the criticisms were that (a) internal human rights violations are not the same as threats to peace, (b) UN military action violates Haiti's sovereignty, (c) military actions in the Caribbean never work, (d) it is illegitimate to undertake UN-authorized military action where one country provides the bulk of the force, and (e) action in Haiti is not in the interest of the United States. ${ }^{256} \mathrm{He}$ minimized these criticisms in favor of justifying the invasion and intervention with the following:

Much more than Haiti is involved in this incident. The credibility of the United Nations, no less than that of the United States, is at stake here. The United States has a major interest in the maintenance of the United Nations as an effective and legitimate instrument of policy. If the United Nations fails to protect elected governments and their peoples from ruthless military renegades, especially when the United

\footnotetext{
${ }^{256}$ Reisman, W. Michael (1995). "Haiti and the Validity of International Action." Faculty Scholarship Series. Paper 884, 83.
} 
Nations has certified the election of those governments as free and fair,

it will have no credibility or legitimacy where it counts-with the

peoples of the world. ${ }^{257}$

The Haitian political and economic situation warrants intervention because of Haiti's geopolitical significance to the North (United States and United Nations). This political conundrum points to Haiti as exceptional because of what their crisis situation means for foreign interests, and not Haiti or its citizens per se. Further, the criticisms Reisman identified and then dismissed are instructive for understanding the role of the international community and the United States in particular have in influencing what ultimately happens to Haiti.

By the time Brazil came to lead the UN peacekeeping operation in Haiti, a longstanding pattern of historical and political crisis that justified foreign intervention had already been established. However, Brazil's participation in MINUSTAH was an exception because the mission contained a Chapter VII mandate allowing the use of force, which runs counter to Brazil's position on non-intervention in the affairs of sovereign states. For this reason, Brazil prefers to participate in Chapter VI engagements that limits the use of force. According to Santos and Cravo (2014), the principle of nonintervention is "perceived as responsible for keeping the peace in South America over the last 150 years and freeing the region from external influence." 258 Thus, the notion of

\footnotetext{
${ }^{257}$ Ibid. 84

${ }^{258}$ Santos, Rita and Cravo, Teresa Almeida (2014). "Brazil's Rising Profile in United Nation Peacekeeping Operations since the End of the Cold War." Norwegian Peacebuilding Resource Centre (NOREF).
} 
crisis has been applied to Haiti at the international, regional, and state levels in an exceptional manner in the case of Brazil.

\section{CONTEXTUALIZING CRISIS - BRAZIL}

Brazilian crisis can be described by its cyclical political and economic instability. Brazil has also been described as the "once and future country," signifying that it was once great and will be great again. Brazil's bouts with repetitive economic boom-andbust cycles and political difficulties have not warranted the application of crisis in a similar manner, as Beckett cited that the case is with Haiti.

In 1964, the military seized power amidst a combination of political, economic, and social issues. Between 1964 and 1989, Brazil was ruled by an authoritarian, military regime. Additionally, a new constitution in 1967 and amendment in 1969 severely restricting political and civil rights and liberties. The Brazilian military government held presidential elections in 1964, 1966, 1969, 1974, 1978, 1985. The first free direct presidential election did not occur again until 1989. The early years of this period (19681980) are referred to as the "Brazilian Miracle" because of Brazil's exceptional economic growth under military rule. The height of the Brazilian Miracle coincided with the presidency of Emílio Garrastazu Médici between 1969 and 1974. Under his leadership, there was heightened detention, censure, intimidation, and torture carried out by the Brazilian military and extrajudicial death squads.

The late 1970s through the 1980s are referred to as the "Lost Decade" for countries in Latin America. The Lost Decade represents a time of economic stagnation when these countries could no longer sustain the rate and level of indebtedness to 
international banks stemming their macroeconomic policies of the 1970s. According to Márcio Moraes Valença, Brazil's indebtedness dates back to 1822 when it agreed to pay an indemnity to Portugal as a condition of its independence. ${ }^{259}$ "From that date until the early decades of this century, the British dominated the credit market to Brazil but were later overtaken by the Americans. ${ }^{260}$ However, the author specifically attributed Brazil's 1980s debt crises to two factors: (a) "shady deals" the military dictatorship made and (b) "unfavorable" terms of agreement on loans that had to be rescheduled for non-payment.

Arguably, the 1960-1980s can been seen as one of Brazil's darkest economic, political, and social times, had it not been for the period of the "Brazilian Miracle." The international community did not make the diagnosis of foreign invasion or intervention despite clear evidence of economic and political crisis. I would argue that Brazil's economic successes between the 1960s and 1980s provides an example of the international community the application of the notion of crisis to Brazil differently than Haiti. The notion of crisis is framed as a descriptive experience and is not necessarily viewed as intrinsic to Brazilian society.

\section{THE RISE OF BRAZIL AS A DEVELOPMENT PROVIDER}

Following the Lost Decade of the late 1970s and 1980s, Brazil began a rise in stature politically and economically. Politically, Brazil became more powerful in the

\footnotetext{
${ }^{259}$ Devlin, Robert and FFrench-Dave, Ricardo (1995). “The Great Latin American Debt Crisis: A Decade of Asymmetric Adjustment.” Revista de Economia Politica, julho-septembro, 15(3)59.

${ }^{260}$ Ibid. 21.
} 
international affairs through soft power; ${ }^{261}$ similar to the Global South, Brazil

experienced sustained economic growth. ${ }^{262}$ Brazil's favorable status in the 2000s was reflected in its shift into becoming primarily a provider of development assistance to other Southern countries. ${ }^{263}$ According to Costa Vaz and Inoue, Brazil negotiated with the United Nations Development Programme for a gradual approach to phasing out countries that were donor countries receiving development assistance. ${ }^{264}$ Over the course of Lula's administration, development cooperation with other countries increased. Figure 2 shows that Brazil increased its foreign assistance by $60 \%$ between 2005 and 2010 with an average growth of $8 \% .{ }^{265}$

\footnotetext{
${ }^{261}$ Dauvergne and Farias (2012). 903.

${ }^{262}$ Inoue and Costa Vaz (2012). 508.

${ }^{263}$ Cabral and Weinstock (2010). vi.

${ }^{264}$ Costa Vaz and Inoue (2007). 17.

265 Troilo, Pete. (2012). "Setting Its Own Course, Brazil Foreign Aid Expands and Evolves." DEVEX. Accessed January 20, 2017. https://www.devex.com/news/setting-its-own-course-brazil-foreign-aidexpands-and-evolves-78631.
} 
Brazilian Foreign Assistance (2005-2010)

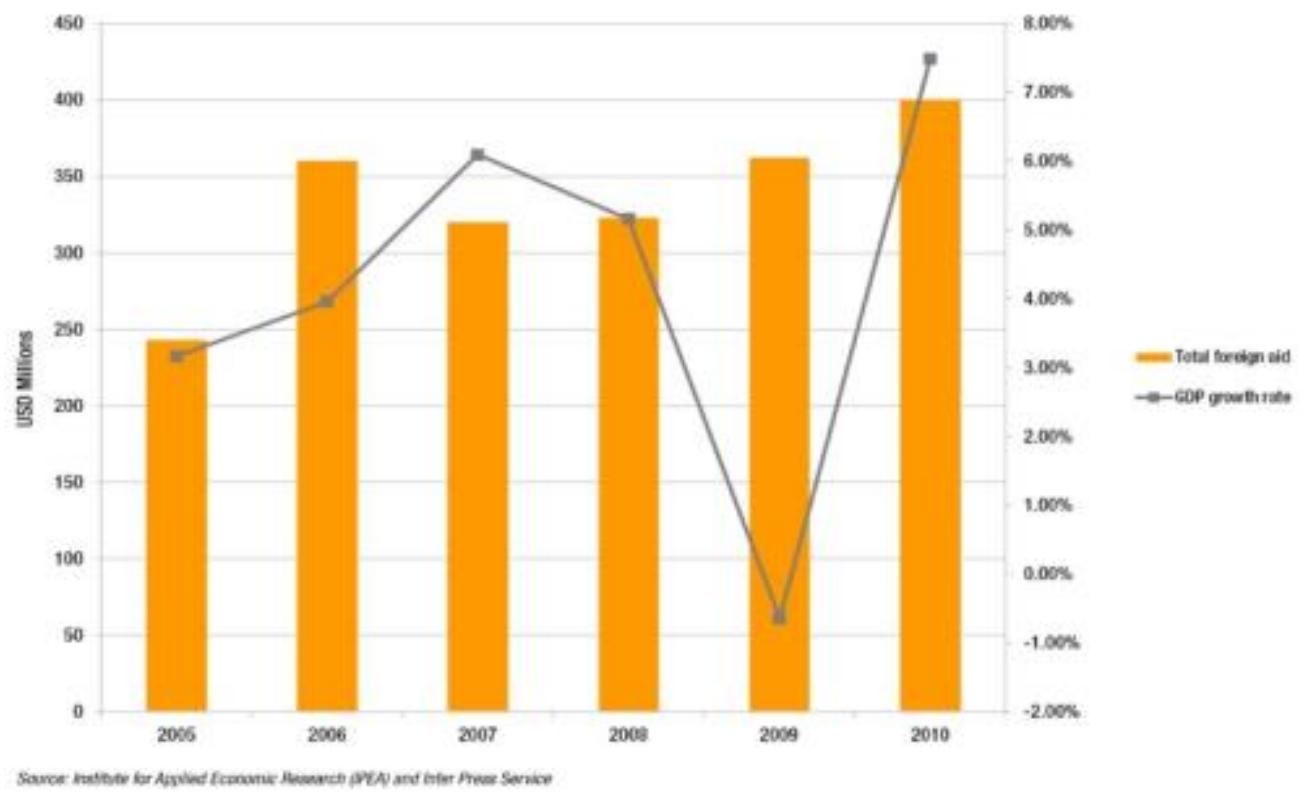

Figure 2. Brazilian foreign assistance (2005-2010).

Source: Institute for Applied Economic Research (IPEA) and Inter Press Service cited by Pete Troilo (2012) in "Setting Its Own Course, Brazil Foreign Aid Expands and Evolves." DEVEX. Accessed January 20, 2017. https://www.devex.com/news/setting-its-own-course-brazil-foreign-aid-expands-and-evolves78631

Further, Brazil began to increase its numbers of new technical cooperation projects (through ABC its development agency) with other countries with 23 new projects in 2003 to 413 in 2009, and increasing the number of recipient countries it provided technical cooperation to from 21 to $58 .{ }^{266}$

Despite the fact that Brazil began to significantly increase the amount of resources allocated to technical cooperation with the South including supplemental peacekeeping in support of its participation in MINUSTAH, its investment in South-South cooperation is not indicative of a sustainable commitment. According to Burges (2007), the Brazilian

${ }^{266}$ Cabral and Weinstock (2014). 188. 
government exhibits "a combination of unwillingness and inability" [...] "to finance its South-South strategy in South America outright" during the Cardoso and Lula administrations. ${ }^{267} \mathrm{He}$ continues that "Rather than subsidizing the production or purchase of goods with government payments, attention was again turned to the capacity-building and information lacunae-addressing precepts at the heart of the neostructuralist approach." ${ }^{268}$ Cabral and Weinstock's research study on Brazilian technical cooperation found significant operational weakness at $\mathrm{ABC}$, the flagship development agency:

Despite the growing number of SSC projects, ABC is understaffed, with only 160 employees in total. Of these, approximately 100 are working directly on technical cooperation and managing more than $400 \mathrm{SSC}$ projects across 58 countries. This shortage is aggravated by the fact that a significant number of employees comes from Itamaraty, being either career diplomats, chancellery officials or chancellery assistants $[\ldots]$. As such, they can be relocated to other areas according to the MRE's needs and interests. ${ }^{269}$

This expansionist period in development cooperation with other developing countries came at the expense of administrative planning and forecasting.

I would argue that Brazil actively sought to distance itself from its authoritarian past and economic depressed years through its pursuit of South-South cooperation as foreign policy strategy. Brazil's middle income and middle power status was consolidated during the period of its active engagement in development cooperation with

\footnotetext{
${ }^{267}$ Burges (2007). 1350.

${ }^{268}$ Ibid.

${ }^{269}$ Cabral and Weinstock (2010). 9.
} 
a foreign policy driven by South-South cooperation. The ongoing and internationally focused crisis situation in Haiti presented an opportunity for Brazil to be perceived as a big developing country versus struggling, crisis-ridden politically and economically. In a sense, Brazil needed Haiti, and Haiti's crisis represented a solution to Brazil's crisis image abroad. In the rest of this chapter, I will present the qualitative findings of the case study.

\section{FINDINGS}

This section includes the findings of the study derived from the qualitative content analysis described in the previous sections. I used four semi-structured interviews, 12 open-ended survey questionnaires, and archival documents as the data sources. The information for the study came from a population of current and former leaders and officials in Brazil and Haiti who have professional, diplomatic, or political experience in engaging in the South-South cooperation and scholar-practitioners on Latin America, Brazil and Haiti. I selected the participants through purposive sampling with the following criteria: (a) having a clear understanding of the SSC framework, (b) having experience in being involved in making decisions or implementing policies pertaining to South-South cooperation, (c) having relevant experience and knowledge of South-South cooperation in both Brazil and Haiti, and (d) being willing to participate in either face-toface or online individual semi-structured interviews or accomplish open-ended survey questionnaires. I analyzed all of the collected data through qualitative content analysis following the guidelines of Mayring (2003). The findings are organized into three subsections, where each sub-section addresses a corresponding research question: 
1. How do Brazil and Haiti benefit from engaging in the South-South cooperation framework?

2. How challenging is the SSC framework for Brazil and Haiti?

3. How is engaging in the SSC framework strategic for both Brazil and Haiti?

The three sub-sections are: (a) benefits of engaging in the SSC framework, (b) challenges from engaging in the SSC framework, and (c) strategic plans for engaging in the SSC framework. Under each sub-section, I will present the themes and sub-themes according to the number of mentions, in which the theme with the most number of mentions is presented first. I will provide excerpts from the three data sources to support the findings. A summative table is provided at the end of each sub-section.

\section{Benefits of Engaging in the SSC Framework}

This sub-section addresses the first sub-question, which includes the findings pertaining to the benefits of Brazil and Haiti for engaging in the SSC framework. I divided the themes into benefits for Haiti and benefits for Brazil. The sub-themes for Haiti are (a) socioeconomic and (b) military and security. The third theme represents an anomaly with findings pointing to the benefit for Haiti as (c) more beneficial to Brazil. The themes and sub-themes are summarized in Table 11 at the end of this sub-section

\section{Socioeconomic Benefits for Haiti}

Being a low income, low development country, Haiti has benefitted from its cooperation with other Southern countries, particularly from Brazil, as stated by the 
participants. The majority of the participants mentioned multiple times that Haiti has received socioeconomic benefits from the SSC framework with Brazil. The respondents shared how South-South cooperation has helped Haiti in socioeconomic issues on poverty, development of agriculture and infrastructures, and foreign investments. A high-ranking Haitian government official and elected official said that:

One of them main advantages of South-South cooperation would be the mutual understanding of what is needed. As we [the South] have tackled poverty on all fronts, there's a deeper understanding of what it takes to deal with that poverty or target the people. And they [Brazil] send in know how to allow for a better understanding based on the South-South idea.

A high-level consultant to the Haitian government expanded upon the idea that the South offers Haiti's options that were not present before when he stated:

Traditionally, Western capitals namely Washington, Ottawa and Paris, and then obviously those of Europe, traditionally impose many times on Haiti. At the end of the day the Golden Rule "he who has the gold makes the rules." Haiti has been under financial issues for as long as we can remember. Haiti is not necessarily fully sovereign in its decision-making and has to respond to different supranational interests or international interests. [Haiti] having a new partner like Brazil, who does not necessarily respond in the same fundamental way as the North in the elaboration of its policies... certainly gave a new impetus to Haiti to explore options in agriculture or energy or otherwise. 
In a document on Brazil-Haiti cooperation received from the Brazilian Ministry of Foreign Affairs Division of the Caribbean of Itamaraty, ${ }^{270}$ the author outlined specific details on bilateral projects:

In 2011, with the beginning of the new government in the Caribbean country, Brazilian cooperation has managed to successfully complete the project "Water tanks to capture and store Rain Water in the Region of Ganthier- Phase I, " building 70 tanks in places of difficult access in the region of mountains, accompanied by the training of agents and local organizations in the technical construction and water management. During the evaluation of the project, one of the most important contributions was the reduction of disparities between urban and rural areas in the municipality of Ganthier. Its most significant social impact was releasing women and children from the obligation traditionally assigned to them to fetch water. It is believed that in this way, the women of the region may exercise economically profitable activities, and children can attend school.

Haiti has also benefitted from the creation of the HRF established by the Haitian government and the international community in order to finance post-2010 earthquake reconstruction of which Brazil is a leading contributor. As of September 30, 2016, the HRF has received USD \$401.40 million of USD\$411.40 million pledged cash donations from 19 donor countries. ${ }^{271}$ As stated in Chapter 2, Brazil was the first to contribute to

\footnotetext{
270 Brazilian Ministry of Foreign Affairs; Division of the Caribbean for Itamaraty, e-mail communication to author, "Subject: Cooperation Brazil-Haiti." October 5, 2016.

271 The World Bank Group (2016). Haiti Reconstruction Fund Financial Report prepared by the Trustee as of September 30, 2016. 6. Accessed December 16, 2016.

http://www.haitireconstructionfund.org/documents/steering_committee/en.
} 
the fund and second to the United States. A high-ranking Haitian government official and elected official spoke on the import role Brazil has served with the fund, however expresses concern for the future of South-South cooperation for both countries when he stated:

The other thing is Haitians have received [USD $\$ 65$ million dollars from the Haiti Reconstruction Fund from Brazil. So, Brazil was very aggressive in the manner they contributed. They have been one of the most visible partners in the post reconstruction era. There have been two government changes in Brazil. We [Haiti] do not know what the future holds for it [South-South cooperation]. So, it's difficult to say today what South-South cooperation is going to be when there is a different government for both Haiti and in Brazil.

From the survey questionnaires, respondents spoke of the potential of the South-

South cooperation for Haiti. A high-ranking U.S. government official claimed that: Haiti could benefit from the Brazilian expertise in critical areas that are central to the development of the Haitian economy e.g. agricultural development/food security, energy efficiency/climate change alleviation and more. Brazilian technical experts can spend time in Haiti working with local leaders and experts in a progressive yet hands-on manner.

A scholar-practitioner on Haiti added that:

Politically, it's about benefits, and I think it's a particular type of capitalism framework that Brazil can offer Haiti. It is my understanding that certain types of industry could be [an] important model to think about how and to harness SouthSouth cooperation [between the two countries]. They [Brazil] can provide 
education, as in the ways they can think about agricultural industries and obviously, their airlines, airports and airplanes. I would also say thinking about ways to promote sporting industries is also critical. Brazil has been quite successful.

This respondent also addressed Brazil's inspirational role and potential to positively influence Haitian society when he opined that Brazil can inspire new ways of approaching public policy around education and race:

I think there are different ways Brazil went through an affirmative action movement in the 1970s, which made some headway for many of the black Brazilians and Afro-Brazilian to enter into various sectors within the educational system and industries. By no means is it [Brazil's affirmative action movement] where it should be, but that [movement] could be quite influential for other nations and an inspiration for countries like Haiti to think about ways to educate its populations.

The respondent also cited that:

Haiti could benefit from engaging in South-South cooperation because there is a kind of a racial component emphasis of blackness, working class... the poor.

That is critical. And if other nations could understand how we [Haiti] can bring in the working poor, the people that have been marginalized into the working class and find ways to educate them, find ways to celebrate them culturally with what these peoples have contributed to the nation would be beneficial. That could mean bringing them in through the arts, media as well as into the political realm. [...] 
It's about elections, it's about class and it's about promotion of agriculture that Haiti can learn from Brazil.

Haiti benefits from South-South cooperation with Brazil in tangible and intangible ways. A World Bank development and disaster relief specialist and scholar-practitioner stated "Haiti benefits from Brazilian government and NGO development experience and by having professional soldiers, some of African origins, as MINUSTAH troops and officers." This draws attention to Brazil's inspirational role in the SSC framework, particularly around inspiring the majority black population on the island when they see other black individuals in positive leadership roles.

Though respondents found that the benefits the SSC framework offers Haiti are at once immediate and direct with great potential for more, their cooperation is also believed to be interrupted. According to the high-level consultant to the Haitian government, "Haiti could have benefited technically with this corporation had it been taken to the end game... we would have had Brasilia invested in Haiti and creating jobs." A high-level advisor to the Haitian government expressed a similar sentiment, citing examples of breaks in continuity:

But, this [Artibonite River Dam project] is the biggest thing that Brazil had to offer Haiti. That's all that I can recall. The Artibonite project used Brazilian engineering. And they took a very holistic approach such as flooding an artificial lake that leads to generating energy that distributes energy. Let's have systems in place so that people pay for the energy. Let's have an irrigation system. Let's do land titles. The Artibonite plan was very very detailed. It's a real shame what actually did happen. The last I heard about this project was that the Haitian 
government was looking into getting the Chinese to finance it with the Chinese Development Bank. The project cost 160 million and Brazil basically said I will put up 40 but you [Haiti] will have to raise the other 120 . So, the 120 needs to come from somewhere else. The only other tangible cooperation they had with Haiti was the donation of 30 or 40 ambulances they brought. There was a little technical cooperation in agriculture and this and that.

A 2014 news report by the Haiti Reconstruction Fund entitled "USD\$38.6 Million for Budget Support from Haiti Reconstruction Fund" contextualizes the example given by the respondent. The article states that "USD\$38.6 million representing USD\$US74 million in funding between 2010 and 2014 had been disbursed to the Haitian government in support of its budget. ${ }^{272}$ However, the same report detailed that another USD \$56 million had been identified for energy, agriculture, health, and professional training projects through the reallocation of USD $\$ 40$ million that had previously been set aside for a hydropower dam on the Artibonite River "at the request of the Brazilian government." 273 According to a 2012 new article reported by Folho de S.Paulo on September 1, OAS - a privately-owned engineering and infrastructure multinational conglomerate - intended to provide construction work on the Artibonite River Dam hydroelectric plant; however, OAS lost interest after setting up a logistics base in Haiti. ${ }^{274}$

\footnotetext{
${ }^{272}$ Haiti Reconstruction Fund (May 2014). "US\$38.6 Million for Budget Support from Haiti Reconstruction Fund,” May 28, 2014. Accessed October 16, 2016. http://www.haitireconstructionfund.org/news_en.

${ }^{273}$ Ibid.

${ }^{274}$ Machado, Renato (2012). “OAS Paralisa Obra no Haiti e Quer Receber Indenizaçã.” Folho de S.Paulo, September 1, 2012. Accessed on February 22, 2017. http://www1.folha.uol.com.br/fsp/mundo/63899-oasparalisa-obra-no-haiti-e-quer-receber-indenizacao.shtml.
} 
This example points to a Brazilian inspired initiative that was interrupted before outcomes could be produced. Brazil made an initial donation of USD \$55 million to the HRF and then actively sought the remaining USD $\$ 40$ million from the North to finish constructing the dam. If Brazil, who initiated the Artibonite River Dam project, received USD $\$ 40$ million from the HRF, it would have in effect represented a reimbursement on its initial USD $\$ 55$ million donation to the HRF. Ultimately, the Haitian government signed a Memorandum of Understanding with the Chinese government to finance the Dam at USD $\$ 240$ million. ${ }^{275}$ This example also points to Brazil's exhibiting regional leadership through multilateral for a, which were closely related to gaining access to opportunities and markets in the region. However, Brazil did not complete the project by either public sector or private sector trajectories.

This same high-level advisor to the Haitian government also gave another example of the introduction of a social-economic program for women and children that began as a bilateral initiative between Brazil and Haiti and grew to include the Dominican Republic and required Venezuelan financial assistance.

[Haiti] sent teams to Brazil to learn and understand Fome Zero/Zero hunger and Bolsa Familia. This was really the first time in Haiti's history any social program had been instituted. It's great. It was being funded by Venezuela's oil money. It was their first time ever...that people were getting monthly stipend when moms would send their kids to school with the conditional cash transfers. So they kind

\footnotetext{
${ }^{275}$ Rogers, David (2015). "Major Power Boost for Haiti as Chinese Firm Agrees to Finance \$240m Dam." Global Construction Review, February 10, 2015. Accessed on December 16, 2016.

http://www.globalconstructionreview.com/news/major-power-boost-haiti-chi8ne8s8e-f8i8r8m-a8gr8ee/.
} 
of built the program on the Brazilian model. But do you know who gave the technical cooperation to set it up? It was the Dominican Republic. That's interesting...well I guess interesting but makes sense since they're right there and they do it as well. But the whole idea was if Lula lifted forty-something million people out of poverty into the middle class we can to. But now they're [Brazil] sliding back into maybe not poverty but certainly not where we would hope they would be.

Brazil is well-known for the success of its national hunger programs such as Bolsa Familia (Family Purse) and Fome Zero (Zero Hunger) and is with providing technical assistance to other governments throughout the South. Analogous to the Artibonite River Dam Project, implementation of this Brazilian initiative required financing from another country.

\section{Military and Security Benefits for Haiti}

Aside from socioeconomic benefits, Haiti received military and security benefits from the SSC framework, especially after the massive 2010 earthquake. A high-level advisor to the Haitian government stated that Haiti has received a significant sum of donation from international assistance; however, Brazil provided Haiti with additional military protection. A high-level advisor to the Haitian government stated that:

In Haiti after the earthquake, the entire world poured into Haiti. It was a big deal to Lula and Dilma to say we're helping Haiti. There are 3,000 Brazilian troops in Haiti that rotate every 6 months so after 5 years you're looking at 30,000 Brazilian 
troops that have been through Haiti. They go back and they talk about it and gives them the sense of Brazilian pride that we can take care of a few.

Similarly, a high-ranking Haitian government official and elected official shared:

The fact is that the Brazilians helped stabilize Haiti for over 11 years with their military presence. We find that Brazil contributed greatly to the Haiti Development [Reconstruction] Fund. It was another sign of success. We achieved the clean energy with that as another sign of success. We have the success when we define it as the successful implementation of these projects. Brazil's Division of the Caribbean from Itamaraty report on improving public security through training 30 Haitian police officers through courses such as "Technical training for instructors of defensive tactics: police self-defense" and "Training of the Haitian National Police" implemented in partnership with the Brazilian Federal Police. A Latin Americanist scholar added:

Against this background, it should be emphasized that the size of the Latin American presence since 2004, both for the landing of peacekeepers as well as the large number cooperating in the region and the experience of interaction developed, is unprecedented in the history of the Caribbean country.

However, not every respondent viewed Brazil's presence in Haiti as positive nor its contributions to development impactful. A former high-ranking Haitian official and political appointee strongly protested the military and economic presence of Brazil in Haiti, while making reference to Brazil as an "occupying force:"

Going back to 2004...the situation has gotten worse in Haiti even though Brazil was the leading country that spearheaded the transition from the coup against 
Aristide from the election in 2006 to 2010 . None of those areas from 2006 to 2010 when there was the earthquake was the economy good...even with the election and Haiti having more money because of Petrocaribe from Venezuela. And, Brazil was a key partner in Haiti responsible for MINUSTAH, the occupying force. The statistical information on health, jobs, economic development have not gotten better. In fact, the country's economic growth went down instead of going up. So, therefore there has not been much of a change for Haitians for having Brazil there as a partner.

Additionally, this respondent stated:

Remember Brazil was an occupying force. Brazil was the head of the occupying military force in Haiti. Brazil had new markets. Haiti is the largest country in the Caribbean basin and a large consumer market. Brazil was there as an occupying military being the regional military power in the region. Haiti provided Brazil an opportunity. Now the obstacles...obviously the first one is there was no real massive grand plan for economic development when Brazil came in. Brazil came in to contain the political situation that the U.S. did not like and the French did not like. They used Brazil as a proxy to make sure that the ruling elite remain and there was no change in Haiti. So, therefore they did not come with an agreement to do any kind of development in Haiti. And besides we have to remember if Brazil wanted to bring development to Haiti, they had to compete with other companies that was already there... the French companies... the Dominican companies. So, one wonders whether Brazil wanted to compete with those companies. 
The high-level consultant to the Haitian government predicted that the likelihood of future Brazilian military assistance to Haiti would be weak:

I don't think you're going to see Brazil again with what they did with Haiti leading the military component. I don't think you're going to see that from Brazil for very long for at least a generation...if ever.

A Brazilianist acknowledged the problem Haitians have with the presence of MINUSTAH by stating, "MINUSTAH is actually challenged by many Haitian voices." However, a Scholar-practitioner and Latin Americanist cited that the benefits that Haiti receives from through cooperating with the international community cooperation includes Brazil outweighs the drawbacks:

Haiti has benefited much from external cooperation including Brazil’s. MINUSTAH, which in my view has been an important mission. The fact that it has not accomplished many of the expectations Haitian’s might have had does not render its accomplishments and importance mute.

\section{Benefits for Haiti are More Beneficial to Brazil}

Some participants believed that Brazil received more benefits than Haiti for engaging in the SSC framework. A high-level advisor to the Haitian government explicitly said that, "Brazil gets a whole lot more out of its cooperation with Haiti and still does." A high-level consultant to the Haitian government sought to explain how Brazil's leadership of MINUSTAH was beneficial in the role of a provider of SouthSouth cooperation:

Brazilian military leadership also brought with it other areas of corporation [such as] economic cooperation, police cooperation, agricultural infrastructure. Now as 
it relates to Brazil; South-South cooperation is an instrument of economic development for Brazil in countries. Forget the last 12 to 24 months what you've seen with regards to Brazil [allegations of high-level corruption] and multilatinas. What we call multlatinas are Brazilian multinational conglomerates. But, for the past 16 years the Brazilian companies have dominated in regions where they previously had no presence prior. In Africa mostly but also in Latin America where usually European and North American Anglo-Saxon groups had all of the big infrastructure projects, all the big concessions or oil... of hydroelectric dams. Suddenly you started seeing the political agenda of South-South cooperation and [with it] came a lot of new deals for Brazil to expand internationally. And grow significantly to the point of becoming some of the biggest engineering and construction firms in the world.

This respondent addressed the importance of Brazil's political and economic nature of Brazil's South-South cooperation agenda in the Global South. Thus, Brazil's engagement in South-South cooperation with Haiti is regarded as instrumental in increasing the economic presence of Brazil by way of the expansion of Brazilian companies.

\section{Political Power Benefits for Brazil}

Some participants believed that engaging in the SSC framework has provided benefits for Brazil, although the benefits mainly lay on politics and market opportunities. One scholar-practitioner and Brazilianist wrote in the survey questionnaire that: 
Looking at South-South cooperation today is something that helps Brazil to promote its internationalization. It is easier for us [Brazil] to deal with people from developing countries; it's easier than to deal with people from developed countries where they will be very worried.

This scholar-practitioner and Brazilianist stated that Brazil used to be a closed country; however, Brazil's engagement in South-South cooperation with Haiti allowed Brazil to "relate with developed countries as well, in a more proactive way." A high-level advisor to the Haitian government stated that "Brazil took great pride in being part of the Core group. The Core group in Haiti are the top countries. You have the U.S., France, and Brazil." A high-level consultant to the Haitian government likewise stated that: First you have to understand why Brazil got into Haiti in the first place Haiti. Your go back to 2004 when Lula was just starting his first mandate and he was a year into his mandate. He came with a very different and innovative social economic model in Brazil. And he came also with the ambition to bring Brazil to the forefront of global governance.

Two respondents referred to Haiti as a "laboratory" for South-South cooperation. A scholar-practitioner and Latin Americanist stated:

Haiti has been a great laboratory for Brazil and other Southern countries in the realm co cooperation as they have been able to try out their strategies in this area. I think Haiti has provided them with a great opportunity to test their credentials in a very challenging environment.

A high-ranking Brazilian government official and career diplomat claimed that the South-South engagement of Brazil was highly influenced by the Worker's Party (PT), 
and has contributed to an unconventional diplomacy. The respondent said that representatives were sent to Southern countries for initiatives that were "not exactly representative of professional diplomacy" as defined by the Ministry of Foreign Affairs [Itamaraty].

Six participants believed that Brazil's involvement with South-South cooperation as a development cooperation provider would help with securing a seat in the United Nations Security Council. A World Bank development and disaster relief specialist and scholar-practitioner stated in the survey that:

Brazil's gain is regional — and to a lesser extent, global—soft power, and it enhances its international profile as a relevant global player, which is compatible with its longstanding demand for a permanent seat at the UN SC.

A Latin-Americanist shared:

Brazil assumed military leadership of MINUSTAH knowing the possibility of an eventual success of the mission would involve greater recognition for itself within the UN system, something that could eventually favor their aspirations for a permanent presence in the Security Council.

Another scholar-practitioner on International Development added:

The benefit of engaging in South-South cooperation would go beyond Haiti. Brazil wants to identify itself as a key player in international relations. It's seeking a seat on the UN Security Council... it's about being a regional hegemon... seeking to mobilize support to be viewed as a key actor. They desire to emerge as a regional hegemon. Brazil in the region is partly symbolic and political. They want to be viewed as a key actor. 
A high-level consultant to the Haitian government questioned the legitimacy of Brazil's ongoing quest to secure a permanent seat on the UN Security Council when stating:

Therefore, Brazil in keeping with their own long-term strategy to make the case for systemic reform of Security Council, decided to take on the leadership of the military component of the peacekeeping of 2004. They wanted to demonstrate that they had the shoulders and the backbone of a permanent Security Council member. Twelve years into it, obviously it's fair to say that the Security Council is not for Brazil and members systematically veto Brazil. Brazil's leadership has been seriously eroded first and foremost at home. And I think history will not absolve Lula and what we call the Amorim doctrine. Celso Amorim was the foreign relations minister of Brazil for three terms under Lula and Dilma and then defense minister.

This respondent connected Brazil's unsuccessful quest to obtain a permanent seat on the UN Security Council to Brazil's overall foreign policy that seeks to reform the UN Security Council through its peacekeeping efforts.

\section{Market Benefits for Brazil}

Brazil's presence in Haiti came to be beyond achieving a minimum level of stability and adopted an integrated approach focused on institutional strengthening, promoting development and new markets. A former high-ranking Haitian official and political appointee stated that Haiti provided Brazil with new market opportunities. Specifically, this respondent said: 
It depends on which side you're looking at it. Brazil was looking at new markets in Haiti. For Haiti it did not do that much because Brazil could not change the political landscape in Haiti. There hasn't been much of a political benefit for Haitians. But for Brazilians there's been an increase in their share of the market in Haiti by Brazilian companies.

Table 11 summarizes the two sets of themes and sub-themes of benefits for Haiti and Brazil for engaging in the SSC framework.

Table 11

Benefits of Engaging in the SSC Framework

\begin{tabular}{llc}
\hline Themes & Sub-themes & Number of mentions \\
\hline Benefits for Haiti & Socioeconomic & 22 \\
& Military and security & 11 \\
& More beneficial to Brazil & 5 \\
& & \\
Benefits for Brazil & Political power & 11 \\
& New market & 8 \\
\hline
\end{tabular}

\section{Challenges from Engaging in the SSC framework}

In this sub-section, I will address the second sub-question. Brazil and Haiti encountered various challenges that were endemic of collaboration between two countries 
that had not sorted out what it meant to engage with each other. Challenges they held in common were (a) Haiti is disorganized, (b) economic challenges and (c) corruption.

A high-ranking Brazilian government official and career diplomat indicated that the early years of Brazil's South-South cooperation under the Worker's Party was conducted as a "secret diplomacy" and in part with other governments like Cuba, Venezuela, and Bolivia. A high-level advisor to the Haitian government mentioned issues of discrimination in South-South cooperation. A scholar-practitioner on Haiti similarly shared that "the South-South cooperation framework has a lot to do with whether or not nations really truly see practically non-white nations within the Global South as their equals culturally and politically." A scholar-practitioner and Latin Americanist said that South-South cooperation cannot be taken at face value and it is a mistake that Southern countries make. The participant cited that South-South cooperation has "failed to seriously build on the valuable experience of developed countries" and "has contented itself to criticize in ideological ways that are not always constructive and lucid." A high-level advisor to the Haitian government brought attention to the lack of diplomatic personnel:

I think a larger diplomatic presence in Haiti would have been helpful. There are a lot of troops and a lot of what they do is security-related so the diplomats focused on that. I think what they could have done was to develop guys working at their embassy [...]. The Brazilian diplomatic present isn't that strong in Haiti. I'm not saying they don't have people there but they should have more of an emphasis on that. But, their Brazilian ambassadors were consumed with their military troops than the development. 
Nonetheless, the participants identified three themes as obstacles that Brazil and Haiti encountered as challenges in engaging in the SSC framework. The themes are: (a) Haiti is disorganized, (b) economic challenges, and (c) corruption.

\section{Disorganization of Haiti}

The participants noted that an issue with the SSC framework is that Haiti is disorganized. A high-level advisor to the Haitian government shared how the lack of coordination led to the failed launch of an energy project in Haiti and narrated that the lead up to Brazil's presentation of the Artibonite hydro plant project for Haiti was an example of disorganization. The Haitian president was "running late" to meet with "top Brazilian generals" to discuss the project. It appeared to the Brazilians that the Haitians did not recognize the importance of the occasion as the Brazilian military had spent five or six million dollars putting the design together for the blueprint of the project.

A former high-ranking Haitian official and political appointee explained that the disorganization in Haiti was rooted in communication. They said that, "communication is one of the most expensive development items in Haiti. Therefore, it creates problems for businesses."

\section{Shared Economic Challenges of Brazil and Haiti}

The participants identified funding and investment and allocation of funding as a challenge in the SSC framework. A Brazilianist noted that Brazil is experiencing an economic crisis that affects the sustainability of providing for Haiti. A former highranking Haitian official and political appointee raised a similar concern, and stated that: 
But the big question for Brazil at the moment within Brazilian society is that their economy has regressed. Brazil is unable to support the projects as they used to because there's no money anymore.

A high-ranking Haitian government official and elected official stated that budgeting from other countries was an issue for the SSC framework. This participant stated that:

One challenge of South-South cooperation is the change of government and political will. The [issue being the] budgeting involved for the helping of countries. Brazil is going through a crisis with the political issues with the [Brazilian] oil companies. There are all those scandals so that their foreign outlook is sometimes overshadowed by the domestic issues. The other challenge is that the funds that were given [to Haiti] for the reconstruction is from a global fund so it isn't country-run or country-owned.

A high-ranking official with the U.S. government elaborated in the survey questionnaire that:

Lately it may be more challenging given the recent economic downturn. The government may be hard-pressed to find the resources to invest in R\&D and other knowledge goods at the expense of recurrent expenditure.

A high-level advisor to the Haitian government added that "Haiti had a really tough time and with the Chinese in Latin America" and that the Haitian officials were advised "to be careful" and expressed worry over who will "reap the benefits" of allowing the Chinese to bring "their Chinese workers to build whatever they need to." Furthermore, aid from South-South cooperation may have "created jealousy from other countries" due to having received "free money for Haiti that everyone else has to get as a loan." 
For several respondents, the severity of the economic challenges facing Brazil along with a change in political parties with the impeachment of the president whose party expanded South-South cooperation calls into question the sustainability and viability of Brazil's continued engagement in South-South cooperation. A scholarpractitioner and Brazilianist stated:

In the first Roussef administration, South-South cooperation had lost momentum - and budget. The situation has aggravated in the past few years, with the acting President shifting foreign policy, in direct criticism to the Lula period. [...] I think that this could be a second challenge, and not only about finance but having more actors involved on South-South cooperation. Brazilian society mainly. So I think we need another framework. The government doesn't speak about SouthSouth cooperation anymore.

A high-level consultant to the Haitian government added:

[Brazil's current administration] is sending a message to Washington and to the former allies that the former power has fallen. He wants to reassure financial markets and political leaders in Western capitals that they are no longer flirting with the ALBA countries. South-South cooperation is now an economic doctrine.

\section{Shared Challenge of Corruption for Brazil and Haiti}

Some of the participants perceived that Haiti faced a challenge in corruption that hinders the advances of the SSC framework. High-ranking Haitian official and political appointee narrated that: 
If you're following the situation where Haiti was given millions of dollars between 2000 and $2015 \ldots$ a lot of that money was managed by [an NGO organization]. Some of that money went to the [NGO organization]. I don't know if you read the stories. They got two hundred million dollars and reallocated it. In Haiti, the [NGO organization] workers were given money and were living on a cruise ship.

The high-ranking Haitian official and political appointee continued that:

The [NGO organization] managed the Haitian money to build an industrial complex in the North and they were supposed to hire 10,000 people but less than ten thousand people are in the park now. They're supposed to also build public housing and never finished. So maybe they will but you have to look at the agenda...they chose people with no knowledge about management who were [also] corrupt.

A high-level advisor to the Haitian government shared that international in-kind aid that went through Customs was often held up, and Customs officials "asked for money to let something through." They said that donations such as ambulances could be held up in the Customs office at the airport. A scholar-practitioner on Haiti summarized Haiti's challenge as a combination of political ineptness and issues related to the legal system:

The challenge has been trying to wrestle and overcome the stigma of being politically inept [which includes the] stigma of political chaos and economic, and financial corruption. The country is unstable, and that has been the challenge. How you think about cooperation impacts investment. So, not knowing whether 
the laws will be able to promote external foreign investments in favor of foreign partners has been a legal challenge for a long time. It has been very difficult for foreign investors to own property, [or] run a company.

Conversely, a high-level consultant to the Haitian government believed that the challenges from engaging in the SSC framework mainly stems from the international community. The respondent stated:

I think that the international community knew going in to Haiti it would not have the capacity to absorb the programs and execute them highly, in a fiduciary acceptable way for whoever the donor owners may have been. It was a way for the international community to also default on their own commitment because the engagement was for 10 years and 5 years into it nobody wants to give a dime anymore. They say the Haitians spoiled an opportunity and in a great part is responsible for their own demise. But the thing is that it seems that Haitians have been in a state of post-traumatic stress disorder for so long that they don't know what it is to be normal. We have stripped them of their sovereignty, which strips them of their identity, stripped of their sovereign capacity to respond to natural disaster. We will not allow them to remobilize a military police force or a mandatory service for their youth to serve as a military force. There is the total disintegration of the authority of state, local and municipal areas. Basically, there is lawlessness. There is survival of the fittest and Darwin at its most barest. The international community is in a great part responsible, but not solely responsible. A scholar-practitioner on international development addressed Brazil's historical role in South-South cooperation when making the observation that South-South 
cooperation is not challenging for Brazil however questions the future of the SSC framework under new and different administrations. The respondent stated:

South-South cooperation is not challenging for Brazil ...they have played an important part in the world of South-South cooperation historically. Brazil serves as a voice for autonomy and independence. For Brazil politically, South-South cooperation is the right framework for international relations and international development. But given current economic and financial crises South-South cooperation would require them to be in the forefront and provide technical assistance. They would have to be able to continue providing for Africa and Haiti and the crises would make it difficult. You also have the leadership crises with the departure of the current administration if it happens. A different administration would change their engagement with the developing world. Lula was aggressive. With a new government they may want to do something different. We don't know what the future engagement will be.

The table below (Table 12) lists the challenges that Brazil and Haiti's share in common.

Table 12

Challenges from Engaging in the SSC Framework

\begin{tabular}{ll}
\hline Themes & Number of mentions \\
\hline Haiti is disorganized & 13 \\
Economic challenges & 12 \\
Corruption & 4 \\
\hline
\end{tabular}




\section{Strategic Plans for Engaging in the SSC Framework}

This sub-section contains the responses to third sub-question, in which the participants revealed the strategic plans of Haiti and Brazil in engaging in the SSC framework. Three themes emerged as their strategic plan. The first theme represents a shared plan to (a) cultivate partnership, the second theme (b) Haiti learning to be selfsufficient, and the third theme (c) Brazil's leadership in the South. The themes and number of mentions are summarized at the end of this sub-section.

\section{Shared Strategic Plan to Cultivate Partnership}

Some of the participants believed that Brazil's help came from the Brazilian's "willingness to help." A high-ranking Haitian government official and elected official believed that Brazil and Haiti worked as partners, and stated that:

By adding assistance to the country you get one more hand. It is helpful having a partner in South-South cooperation because a lot times they are similar; culturally, historically, racially or otherwise...geopolitical similarity, so it helps.

A monitoring and evaluation specialist and contractor with USAID believed that the partnership brought positive results to both countries, and stated in the survey that: In concept, the collaborative initiative is positive. It can provide a level of cooperation among nations that respects culture, history and national interests.

Given the recent challenges in Brazil (political, economic and social), a solid 
partnership with another South hemisphere country, in this case Haiti, gives Brazil the opportunity to share its experience, knowledge and commitment as an alternative view to the issues it faces within its own country. Haiti is a country in need of much partnership and extended cooperation with another South nation (Brazil) that understands, at least in part, the demographic, education, and economic infrastructure gives purpose to the larger nation with experience, capacity, and intellectual/experiential resources to share.

A high-ranking official with the U.S. government believed that by partnering with Brazil, "strategically, Haiti may be able to increase the pace of its development by learning from the experiences with the partner state." A scholar-practitioner and Latin Americanist perceived that Brazil partnering with Haiti resulted in "humbling challenges of partnering with Haitian stakeholders and that demonstrating sustainable development results could open the door to better cooperation practices."

A high-ranking Haitian government official and elected official added that the Brazil-Haiti partnership was strategic for both countries:

Two countries decided to work together...So there is humanitarian on one side and geopolitical considerations on the other side to gain some votes. Both countries can benefit and be to their advantage. This cooperation can be beneficial. They have no reason not engage.

\section{Haiti Learning to be Self-sufficient}

Strategically, Haiti aims to eventually attain self-sufficiency. A monitoring and evaluation specialist and contractor with USAID stated that partnership through South- 
South cooperation allowed Haiti to achieve tangible short and long-term leadership stability goals, and added that technical assistance "is a key to building the human infrastructure that will give hope and possibility to its citizens." The framework offers a strategic, though ambitious, path of cooperation that can invest in long term reform." A High-level advisor to the Haitian government explained that Haiti did not only need financial assistance. Haiti also needed "technical training." Member countries of the South tend to provide financial assistance, and Haitians welcomed the technical assistance provided by the United States.

However, in the e-mail communication with the Brazilian Ministry of Foreign Affairs; Division of the Caribbean for Itamaraty, technical assistance provided by Brazil was enumerated, dating back to the promulgation of the Basic Agreement on Technical and Scientific Cooperation in 2004 (signed 1982). The document showed that:

From 2004 to 2009, several actions in the framework of technical cooperation for development were held between Brazil and Haiti. Noteworthy is the project "Management and Reconstitution of Vegetation Cover of Mapou Basin" held in partnership with Spain, which aimed to increase forest and agroforestry for productive, ecological, energy and food purposes; as well as the recovery of degraded areas at risk of erosion, landslides and floods. In its execution, it built a nursery from which 200,000 seeds of native plants were planted in Haiti. It is also worth of notice the success of the project "Promotion of Sustainability vegetable production in the region of Kenscoff," lead by Embrapa and the Ministry of Agriculture Natural Resources and Rural Development (MARNDR), which allowed the creation of a vegetable seed bank in partnership with the 
Association AFE Neg Kombite. They formed about 200 farmers and distributed 150 kits of seeds adapted to soil and climate conditions of the region.

The document also revealed that after the 2010 earthquake, Brazil committed to training Haitian health professionals, and continued with agricultural and infrastructure projects. A high-ranking Haitian official and political appointee narrated why there is a need for technical assistance and the potential of South-South collaboration with: Haiti has been very good in producing local peanuts that are organic peanuts. Peanuts are a basic staple for the people of Haiti and a good source of protein. The famers make money from it. It creates rural jobs. It has a lot of commercial value. The U.S. had an overproduction of peanuts so they decided to put together an economic package that included bringing peanuts to Haiti. Suddenly the farmers that were cultivating their own peanuts in Haiti could not survive on peanuts. The U.S. peanuts are cheaper than the local Haitian peanuts. The U.S. was saying they were helping Haitians with the package but they are killing local production. And once you kill local production, farmers don't have the ability farm their land. So they farmers go to the city but there are no jobs and there are no opportunities. This has been the U.S. policy since the 1980s. The U.S. on behalf of economic aid has killed local production. There is a difference between southern countries and the North. In the 1980s, Thailand went to Haiti and you know what they did. Thailand went to Haiti and opened a technical and research center. They trained the Haitians in production. They produced a variety of grains. With the right production there was an increase production. This is what 
south-south collaboration is. Haiti as a result had large rice production because of the collaboration from Thailand.

A scholar-practitioner on international development acknowledged that the North remains relevant to the South, but the South should seeking greater independence: It's pragmatic and strategic and [however] you can't get rid of the U.S. and other Northern states and institutions but moving away from depending on them in terms of geopolitics is good. Haiti must be smart enough to play the game well and to not be dependent. And they know how to play the game well.

Furthermore, a monitoring and evaluation specialist and contractor with USAID claimed that partnership with Brazil provided Haiti with more opportunities, and a Brazilianist similarly expressed that "engagement with Brazil allows Haiti to diversify its donor contacts to both gain new experience and resources, and to reduce its dependence on traditional donors." Yet, a high-ranking Haitian government official and elected official reiterated the importance of "Brazilian private sector investment in Haiti" for the SSC framework to be sustainable and that "we tried to build efforts with Brazil but where not successful." [...] For any development effort to be successful there is a role for the private sector that does the investment in the economy in strengthening the economy, job creation and profit-making."

\section{Brazil's Leadership in the South}

Although Brazil may be categorized as a middle-income country, Brazil is also considered a forerunner in South America and the Global South. Some of the participants believed that aside from aspiring for a permanent seat on the UN Security 
Council, the strategic plans of Brazil in engaging in the SSC framework also included the intention to lead the South. A high-ranking official with the U.S. government claimed:

This may allow Brazil to strategically position itself as a leader in the South in the provision of technical assistance and act as a knowledge center to other Southern states. This may also allow Brazil to gain diplomatic soft power when trying to advance topics important to its national interest in regional or international fora. A monitoring and evaluation specialist and contractor with USAID expressed the same belief:

Brazil has a legitimate opportunity to be a leader in South nation growth and progress in the coming decades. It can provide a strategy for others, though smaller, nations to embrace ideals, enterprises, and possibilities. Among exports, Brazil can export its progress on human rights (still emergent), its economic (a bit challenged these days) and its commitment to the democratic future (now under close review with the impeachment proceedings). How Brazil emerges from these internal challenges is critical to its role as a leader in the Southern Hemisphere.

One participant looked at Brazil's participation in South-South cooperation as greater than the promoting the principles of South-South cooperation and more in alignment with the realist view of power politics. The scholar-practitioner on international developments cited:

On the surface it appears to be about solidarity, horizontality... [however], it's about realism. Solidarity, that is what's driving it initially. It is about obtaining the Security Council seat. They deserve the leadership role. Their language 
doesn't support it. It's about classic realism, national interest within South-South cooperation.

Further, a scholar-practitioner and Latin Americanist added:

It raises its stature as a major southern power. Brazil believes that by championing a new approach it is carving out space in the global existing architecture. In my view this is important and many of the points advocated by Brazil are relevant to open up a frank conversation about the shortcomings of cooperation in general.

However, one Scholar-practitioner and Brazilianist questioned how deliberate Brazil was in pursuing the SSC framework as a strategy. The participant stated: I just don't know to which extent this was a strategy. In the literature about strategy, there is that may be called "imagined strategy." And, I think this could not be more liked imagined strategy. I mean something that came spontaneously and that later the government identified it as useful for this mean and started promoting it you know. I do not think it was planned from the beginning you know. Maybe for some international organizations that promoted it [it would be true]. Maybe they had something like this in mind. But I'm not sure in the case of Brazil; it was something really, really planned.

Table 13 contains a combination of themes that Haiti and Brazil hold in common (cultivate partnership) and individually (Haiti learning to be self-sufficient and Brazil's leadership in the South).

Table 13 
Strategic Plans for Engaging in the SSC Framework

\begin{tabular}{ll}
\hline Themes & Number of mentions \\
\hline Cultivate partnership & 11 \\
Haiti learning to be self-sufficient & 7 \\
Brazil's leadership in the South & 4 \\
\hline
\end{tabular}

\section{SUMMARY OF THE QUALITATIVE FINDINGS}

Based on the findings from the three sub-questions, several main themes emerged that can explain why Brazil and Haiti engage in a bilateral cooperation. These reasons can be classified as the following (a) political, (b) economic, and (c) leadership aspirations within Latin America and the Global South for Brazil and increasing selfsufficiency for Haiti.

To address the first sub-question, data analysis revealed that the SSC framework has provided benefits for both Haiti and Brazil despite the economic standing of both countries. South-South cooperation has provided mutual benefit in the socioeconomic market of both Haiti and Brazil. Through South-South cooperation, Haiti has also received military and security aid from Brazil. Nonetheless, some participants believed that Brazil received more benefits in the partnership due to the rise in political power, and the opportunity for a new market.

For the second sub-question, the challenges for Haiti and Brazil in engaging in the SSC framework were the disorganization of Haiti, economic challenges, and government corruption. The expense for communication led to the lack of communication in Haiti; as a result, miscommunication and lack of coordination often occurred. Haiti was considered the poorest country in the Western hemisphere, and Brazil has also been 
experiencing an economic crisis, which made economic struggles as a challenge in the partnership. Finally, Haiti's government — particularly the Customs officers-were corrupt and took advantage of donations from international sources.

For the third sub-question, I identified three themes as the strategic plans of Haiti and Brazil in engaging in the SSC framework. The first strategy of both countries was to cultivate partnership. The participants generally regarded the partnership of Haiti and Brazil as mutually beneficial. The second strategy was for Haiti to learn to be selfsufficient. In that way, Haiti may be able to develop its own manpower in the long run. The third strategy involved Brazil's leadership in the South. Brazil has been more economically powerful than other LAC countries, and providing for Haiti has contributed strategically to increasing Brazil's political power in the region and by extension globally.

\section{CONCLUSION}

Prior to the presentation of the study's findings based on content analysis, I situated the application of crisis in political and economic histories of Haiti and Brazil and the rise of the latter as a development provider. Brazil and Haiti both experience political and economic crisis, receive international development assistance, and have been regarded as "exceptional" within the international system. Each country's exceptionalism is regarded differently. For Haiti, the notion of crisis is viewed as intrinsic to Haitian society and for Brazil descriptive of an economic and political cycle the country periodically face as a developing country. Foreign invasion and intervention was applied to Haiti repeatedly between 1914 until the time of the writing of this study 
2017. Further, Brazil's period known as the "Brazilian Miracle" could exist as the same time the Brazilian citizens experienced censorship of the media, political oppression, torture, exile, forced disappearances, rapes, and killings at the hand of an authoritarian regime and military dictatorships without the application of foreign invasion or intervention. I would conclude that Brazil distanced itself from its experiences with political and economic crisis between the 1960s and 1980s through its foreign policy activism under President Lula, which called for an aggressive international cooperation strategy around development cooperation with other Southern countries. Brazil no longer wanted be perceived as a crises-ridden, crisis-prone developing country in need of assistance from the North but one that could act as a regional leader and global player. Haiti figured prominently in Brazil's plan to achieve international recognition and became Brazil's top recipient of Brazil's development assistance.

Contextualizing the notion and application of crisis to Haiti and Brazil anchors the analytical and political analysis of the remaining chapters. First, only one respondent forcefully opposed the presence of Brazil as a legitimate response to the political and economic situation in Haiti. Second, none of the participants suggested foreign intervention or invasion of Brazil while it grapples with it political and economic crisis underway since 2015. Lastly, only one respondent (the same one who opposed Brazil's presence) questioned the impact of Brazilian contribution to development cooperation in Haiti. Overall, this section transitions into answering the central question of the study with a more in-depth discussion of the findings of the study's contributions. 


\section{CHAPTER 5}

\section{A SOUTH-SOUTH SOLUTION?}

\section{INTRODUCTION}

The purpose of this chapter is to examine the overall cooperation framework between Southern countries through the central question, "Why Southern countries engage in South-South cooperation?" based on the collaboration between Brazil and Haiti. Consequently, I divided the examination into three tasks.

The first task began by discussing the findings presented in the previous chapter. The findings followed from the study's sub-questions, which explore the benefits, challenges, and strategic rationale for the application of the SSC framework:

1. How do Brazil and Haiti benefit from engaging in the South-South cooperation framework?

2. How challenging is the SSC framework for Brazil and Haiti?

3. How is engaging in the SSC framework strategic for both Brazil and Haiti? I sourced the findings from qualitative interviews and surveys with leading experts and practitioners on South-South cooperation in Latin America and the Caribbean. The study's participants included high-ranking officials in the governments of Brazil and Haiti, including current and former cabinet members and diplomats. They have been involved in commenting on, setting the agenda, making decisions on, and implementing South-South cooperation in general and Brazil and Haiti in particular. These elite respondents were chosen because they have acted on behalf of the state or in the case of academics possess in-depth, expert knowledge of South-South cooperation in the region. 
Specifically, this task involved discussing the findings within a larger social-political context. This required the use of archival data sources and academic literature.

The second task endeavored to explain the hypothesized relationship between South-South cooperation and development cooperation. The goal was to ascertain whether South-South cooperation affects development cooperation in one of three ways, strengthening, weakening, or having no impact on development in Brazil and Haiti. The findings were used to address the direction of the impact of South-South cooperation on development cooperation in terms of benefits, challenges and strategic rationale for the SSC framework. Figure 3 provides a framework of the graphic representation of the approach taken to answer the directionality of the hypotheses.

\begin{tabular}{|c|c|c|c|c|}
\hline Hypothesis & \multicolumn{4}{|c|}{$\begin{array}{l}\text { South-South cooperation affects development cooperation by } \\
\text { strengthening, weakening or having no impact on development in } \\
\text { Brazil and Haiti. }\end{array}$} \\
\hline \multirow[t]{2}{*}{$\begin{array}{l}\text { Purpose of } \\
\text { the sub- } \\
\text { questions }\end{array}$} & \multicolumn{4}{|c|}{$\begin{array}{l}\text { To explain the hypothesized relationship between South-South } \\
\text { cooperation and development cooperation through the Brazil-Haiti } \\
\text { SSC framework }\end{array}$} \\
\hline & & $\begin{array}{l}\text { How do Brazil } \\
\text { and Haiti benefit } \\
\text { from engaging } \\
\text { in the SSC } \\
\text { framework? }\end{array}$ & $\begin{array}{l}\text { How } \\
\text { challenging is } \\
\text { the SSC } \\
\text { framework for } \\
\text { Brazil and Haiti? }\end{array}$ & $\begin{array}{l}\text { How is engaging } \\
\text { in the SSC } \\
\text { framework } \\
\text { strategic for both } \\
\text { Brazil and Haiti? }\end{array}$ \\
\hline \multirow{3}{*}{ Directionality } & Strengthen & & & \\
\hline & Weaken & & & \\
\hline & No Impact & & & \\
\hline Outcome & & & & \\
\hline
\end{tabular}

Figure 3. Graphic representation addressing the hypothesis framework. 
In the third task, I set out to answer the main research question by connecting the study's overall contributions. The study's contributions include the explanatory framework and qualitative findings. Figure 4 provides a framework of the graphic representation of the contributions for the study's findings.

\begin{tabular}{|c|c|c|}
\hline $\begin{array}{c}\text { Central Research } \\
\text { Question }\end{array}$ & \multicolumn{2}{|c|}{$\begin{array}{c}\text { Why Southern countries engage in South-South } \\
\text { cooperation? }\end{array}$} \\
\hline $\begin{array}{c}\text { Study } \\
\text { Contributions }\end{array}$ & $\begin{array}{c}|c| \\
\text { Findings of the Explanatory } \\
\text { Framework }\end{array}$ & $\begin{array}{c}\text { Findings of the Qualitative } \\
\text { Research } \\
\text {-in-depth interviews } \\
\text {-survey questionnaire } \\
\text {-data source }\end{array}$ \\
\hline $\begin{array}{c}\text { Overall Result of } \\
\text { the Study's } \\
\text { Contributions }\end{array}$ & \begin{tabular}{c}
$|c|$ \\
\hline
\end{tabular} & \multicolumn{2}{|c|}{} \\
\hline
\end{tabular}

Figure 4. Graphic representation addressing the central question framework.

Overall, I took into account the three tasks of the chapter. The tasks were based upon the findings of the study's contributions and data sources. The chapter then segues into the dissertation's concluding chapter.

\section{DISCUSSION OF THE QUALITATIVE FINDINGS}

Benefits for Haiti Engaging in the SSC Framework

Generally, the participants found that the partnership with Brazil provided Haiti with "socioeconomic" and "military and security" development. Brazil provided Haiti 
with humanitarian assistance amounting to USD \$24 million in $2014,{ }^{276}$ and has been providing military and security development since Brazil became the leader of the UN Stabilization Mission in Haiti (MINUSTAH) in 2004. Researchers have estimated that Brazilian spending in Haiti approximated USD\$500-510 million as of 2011. ${ }^{277}$ Participants did not address Brazil's technical cooperation with Haiti in significant detail. Either the participants were unfamiliar with Brazil's bilateral technical cooperation with Haiti, or did not deem Brazil's technical cooperation with Haiti as relevant when responding to the question of benefits for Haiti engaging in the SSC framework with Brazil. The Brazilian government provided an e-mail communication from the Division of the Caribbean for Itamaraty revealing that prior to the 2010 earthquake in Haiti, the technical cooperation spearheaded by the Brazilian Cooperation Agency was largely focused on forestation and agricultural development of Haiti. ${ }^{278}$ Additionally, the 2007 Brazilian Ministry of External Relations document entitled "South-South Cooperation Activities Carried out by Brazil" indicated that Haiti received technical cooperation towards democratic consolidation and organization of local and legislative elections (USD\$1,000,000), electoral observation (USD\$7,486.67), and access to new information and communication technologies (USD\$365.40). ${ }^{279}$ In 2010, per the e-mail communication with the Division of the Caribbean for Itamaraty when the

\footnotetext{
${ }^{276}$ Global Humanitarian Assistance (2015).

${ }^{277}$ Kenkel (2013), 99.

${ }^{278}$ Brazilian Ministry of Foreign Affairs; Division of the Caribbean for Itamaraty, e-mail communication to author, "Subject: Cooperation Brazil-Haiti." October 5, 2016.

${ }^{279}$ Brazilian Ministry of External Relations (2007), 51-52.
} 
earthquake devastated Haiti, the Brazilian government implemented health and safety projects such as a partnership with the Albert Einstein Hospital to combat cholera, and the "Study for Strengthening Actions for the Promotion of Family Agriculture and Food Security and Nutrition (Local Procurement)." Road infrastructure projects also commenced in 2012, and technical training of the Haitian National Police was also conducted by the Brazilian government. ${ }^{280}$ Recently, Haiti completed the "Revitalization of the Ministry of Agriculture, Natural Resources and Rural Development of Haiti's Farm (MARNDR)" project with the donation of a weather station and an irrigation system, as well as assistance with farm infrastructure, all of which contributed to a higher number of corn production in Haiti for the year 2016. ${ }^{281}$ Negotiations for building a vocational training center were also finalized, and the project was proposed to begin in $2017 .{ }^{282} \mathrm{~A}$ project involving the training of the Haitian Health Authority signed in 2010 was due to be completed in $2018 .^{283}$

Brazil is also well known and celebrated for its development cooperation with Haiti in the area of humanitarian assistance (particularly following the 2010 earthquake) and military and security development. Moulin and Thomaz (2016) identified Haitian migrants as "humanitarian" immigrants who fled Haiti following the 2010 earthquake

\footnotetext{
${ }^{280}$ Brazilian Ministry of Foreign Affairs; Division of the Caribbean for Itamaraty, e-mail communication to author, "Subject: Cooperation Brazil-Haiti." October 5, 2016.

${ }^{281}$ Ibid.

${ }^{282}$ Ibid.

${ }^{283}$ Ibid.
} 
and arrived in Brazil seeking a better life. ${ }^{284}$ Brazil received approximately 38,000 migrants of Haitian descent between 2010 and 2015. ${ }^{285}$ In January 2012, Brazil's National Council on Immigration began to issue prospective Haitian immigrants 5-year permanent humanitarian visas under the Brazilian National Immigration Council (CNIg) Normative Resolution n.97, which resulted in their issuing around 50,000 humanitarian visas between 2012 and 2016 and the Brazilian government another 43,871 permanent resident visas. ${ }^{286}$ The adoption of the humanitarian visas by the CNIg is considered a “special immigration policy."287 A February 7, 2012 New York Times article reported that the Brazilian government sent over $\$ 500,000$ in aid to the Acre and Amazonas to support these states who received an influx of Haitian immigrants. ${ }^{288}$ Given the sizeable Haitian immigrant population, I expected that the participants would focus upon and emphasize the importance of the Brazilian governments liberal immigration policy towards Haitians following the 2010 earthquake as a benefit for Haiti.

Furthermore, the qualitative findings revealed little regarding Brazil's existing technical cooperation activities with Haiti, although Brazil largely defines its

\footnotetext{
${ }^{284}$ Moulin, Carolina and Thomaz, Diana. (2016). The Tactical Politics of 'humanitarian' Immigration: Negotiation Statis, Enacting Mobility. Citizenship Studies. 20(5).

${ }^{285}$ Ibid. 596.

286 Rathod, Jayesh and Granja, João Guilherme Casagrande (2016). "U.S. Can Learn from Brazil about Haitian Migration.” Orlando Sentinel. December 10, 2016. Accessed February 21, 2017. http://www.orlandosentinel.com/opinion/os-ed-haiti-migration-lessons-from-brazil-121016-2-20161210story.html.

288 Romero, Simon and Zarate, Andrea. (2012). "Influx of Haitian into the Amazon Prompts Immigration Debate in Brazil.” New York Times. http:/www.nytimes.com/2012/02/08/world/americas/brazil-limitshaitian-immigration.html.
} 
development cooperation as technical cooperation with Southern countries. For the years 2000-2014, the Ministry of Foreign Relations Brazilian Cooperation Agency online database documented 110 South-South cooperation projects with Haiti; all but four have since been deemed "complete." 289 Additionally, the Division of the Caribbean for Itamaraty stated that two bilateral projects have been scheduled for 2016 , with one continuing through 2017. ${ }^{290}$ The scale of Brazil's bilateral technical cooperation since 2004 appears relatively small, given Haiti's population that includes over 10 million inhabitants and scope of ongoing political, economic, and environmental issues. It may appear that Haiti gained a great deal from engaging in the SSC framework with Brazil through the socioeconomic and military and security development benefits.

Nevertheless, the qualitative findings of this study revealed that Haiti could have potentially gained a great deal more from their collaboration, had Brazil placed a greater emphasis on increasing its technical cooperation.

Moreover, participants repeatedly referenced the potential of the SSC framework to benefit Haiti. Participants were keen to address the role that race could play in improving the lives of Haitians through lessons learned from Brazilian innovative approaches to public policies in the realm of education, affirmative action, industry, and culture. According to the CIA World Factbook, Haiti is ethnically 95\% black and 5\% mulatto and white. 291A World Bank development and disaster relief specialist spoke to

\footnotetext{
${ }^{289}$ Brazilian Ministry of Foreign Relations; Brazilian Cooperation Agency (2016). Pesquisa de Projects Online Database. Accessed December 16, 2016. http://www.abc.gov.br/Projetos/pesquisa.

${ }^{290}$ Brazilian Ministry of Foreign Affairs; Division of the Caribbean for Itamaraty, e-mail communication to author, "Subject: Cooperation Brazil-Haiti." October 5, 2016.

${ }^{291}$ Central Intelligence Agency (2016).
} 
mentorship through modeling with the presence of professional soldiers in the MINUSTAH of African origins. A scholar-practitioner of Haiti summed up the potential of the Brazil-Haiti framework for Haiti when alluding to the possible translation of Brazilian successes with improving the social conditions of its Afro-Brazilian population in the context of the majority dark-skinned Black and impoverished Haitian population. The minority elite are mostly lighter-skinned and more affluent. Modest success in this area could present a huge impact on conditions in Haiti-according to a 2012 World Bank household survey, "More than 6 million out of 10.4 million (59\%) Haitians live under the national poverty line of USD $\$ 2.42$ per day, and over 2.5 million (24\%) live under the national extreme poverty line of USD $\$ 1.23$ per day. It is also one of the most unequal countries, with a Gini coefficient of 0.61 as of 2012."292

Included among the sub-themes on benefits for Haiti was the sub-theme that Haiti's engagement with Brazil was "more beneficial to Brazil." The emergence of this sub-theme under "Benefit for Haiti" indicates that for some participants, the SSC framework between Brazil and Haiti does not fully adhere to one of the core principles of South-South cooperation which is "mutual benefit." Since the principles of South-South cooperation are more expansive than traditional Northern assistance, the SSC framework allows for public sector and private sector development. Public sector and private sector development were not found to be a significant benefit that Haiti was either able to capitalize upon or be given the opportunity to develop in its collaboration with the Brazilian government or market. Besides the technical projects mentioned by the

\footnotetext{
${ }^{292}$ World Bank (2017).
} 
Brazilian government, the Artibonite River Dam project and the Viva Rio project were the only initiatives participants identified or mentioned by name. Though the Brazilian model of development cooperation is based upon its provision of technical cooperation, this has not been so in its collaboration with Haiti since the initial signing of the Basic Agreement on Technical and Scientific Cooperation in 1982. Technical cooperation has been modest between the two countries since the agreement was promulgated in 2004 . Overall, the qualitative findings are consistent with Malacalza's assertion that Lula is responsible for Brazilian development cooperation with Haiti with his decision to allow Brazil to lead MINUSTAH. However, the findings contest the traditional notion that Brazil's cooperation focuses primarily on technical cooperation, at least in the case of Haiti.

\section{Benefits for Brazil Engaging in the SSC Framework}

Predominantly, the qualitative findings revealed that Brazil opened up opportunities for political power and a new market through its partnership with Haiti. Some participants perceived that engaging in South-South cooperation was an easier framework for Brazil because coordinating with developing countries is easier compared to more developed countries in the Global North. In addition, South-South cooperation with Haiti enhances the ability of Brazil to promote its internationalization within a political sphere. The qualitative findings also revealed that Brazil's engagement in bilateral cooperation with Haiti could lead to a permanent seat on the UN Security

Council. A permanent seat on the UN Security Council could lead to Brazil gaining more diplomatic power, which would advance their own interests and priorities on a global 
level. There is a basic belief that Brazil's involvement in Haiti could enhance the international profile of Brazil as a regional and global leader.

Being a middle-income country, Brazil has been a donor and a recipient of development; nonetheless, in among the LAC countries, Brazil has gained a strong influence, specifically in Haiti. Brazil played a role in intervening with the Haitian government following the political upheaval surrounding President Jean-Bertrand Aristide when it was decided they would assume leadership of MINUSTAH after the U.S.-led Multinational Interim Force departed 3 months following his ousting. Following the review of the document by Marroni de Abreu (2013) and Vazquez (2013), the Brazilian Cooperation Agency (ABC) had supported the act of enhancing their leadership practices in low development countries of the South. ${ }^{293}$ Brazilian engagement in Haiti could show their effective leadership in a country that has lots of challenging problems. Specifically, the challenging case of Haiti serves as an opportunity for Brazil to experiment, test and apply leadership through its development cooperation activities. Hirst and Nasser makes mention of Brazil's peacekeeping operation as a "challenging learning process" as it sought to develop and a "Brazilian way" of peacekeeping through its leadership command of the MINUSTAH. ${ }^{294}$

\footnotetext{
${ }^{293}$ Vazquez, Karin (2013). "Enhancing Management Practices in the South: Study on Country-Led Practices." United Nations Office for South-South Cooperation. New York: United Nations Office for South-South Cooperation. Accessed September 28, 2016. http://tcdc2.undp.org/GSSDAcademy/ResourceCentre/docs/SSC_Case_Designed_Web.pdf ; Marroni de Abreu, Fernando Jose' (2013). “A Evolução da Cooperação Técnica Internacional no Brasil.” Mural International, 1(2): 3-16.

${ }^{294}$ Hirst, Monica and Nasser, Reginaldo Mattar (September 2014). "Brazil's Involvement in Peacekeeping Operations: The New Defence-security-foreign policy nexus." Norwegian Peacebuilding Resource Center, 1.
} 
Further, pacification methods employed by the Peace and Pacification Units in Rio were "first experimented with in Port-au-Prince." 295 Since 2004, MINUSTAH's Community Violence Reduction Unit has implemented violence reduction intervention in Haiti through its institutional support of a Rio de Janeiro based Brazilian NGO, Viva Rio. ${ }^{296}$ In 2006, in response to concerns of then President René Préval about the presence of security details (MINUSTAH and the National Haitian Police) in slum areas such as Cité Soleil, Viva Rio made the following recommendation given the situation on the ground in Haiti:

The strategy suggested for MINUSTAH was to use Latin American expertise and to apply the experiences of the various UN peacekeeping battalions to the Haitian context. At the time it was initiated, seven of 12 troop contributors to the mission were South American states. In the case of the Brazilian battalion, the Haitian situation was understood in terms of their experience of working in favelas and with gang violence in Brazil. ${ }^{297}$

Thus, Brazil derived benefits that directly helped its domestic security situation while at the same time fulfilling its international responsibilities. In this instance, the groundwork

\footnotetext{
${ }^{295}$ Ibid.

${ }^{296}$ Yazdani, Mariam, Bercovitch, Daniela and Charles-Voltaire, Jane (2014). "Knowledge Transfer on Urban Violence: From Brazil to Haiti. Environment \& Urbanization. International Institute for Environment and Development (IIED). 26(2): 457-468.

297 Ibid. 459.
} 
for the development cooperation emerged from experiences gained in Brazil and then later in Haiti through the nexus of UN peacekeeping and security.

The findings pointed to Haiti offering Brazil a new market for Brazilian goods. A high-level consultant suggested forgetting scandals regarding Brazilian officials and “multilatinas" and instead focusing on what these multilatinas or Brazilian multinational enterprises (MNE) ${ }^{298}$ have accomplished in markets commonly reserved for "European and North American Anglo-Saxon" entities. Brazil is largely regarded as a closed economy when compared to the more liberal economies in LAC such as Chile. Thus, engaging in bilateral cooperation with other Southern countries including Haiti could lead to an expanded market economy. The study participants perceived that Brazil could increase its market share by engaging with Haiti as Haitian people continued to be influenced by Brazilian culture through popular media and goods.

According to the Brazilian newspaper Folho de S. Paulo, in 2008, while on a trip to meet with Brazilian troops in MINUSTAH, President Lula sought to stimulate private investment in Haiti by inviting businessmen from energy and infrastructure as well as contractors. $^{299}$ The news article elaborated that multinational conglomerates Odebrecht, Andreade Guitierrez, and Camargo Corrêa were invited. ${ }^{300}$ Previously, a Brazilian construction company (name not released at the time) received USD $\$ 80$ million from the

\footnotetext{
${ }^{298}$ See Ferreira da Silva, Jorge, da Rocha, Angela, Carneiro, Jorge. (2009). "The International Expansion of Firms from Emerging Markets: Toward a Typology of Brazilian MNEs." Latin American Business Review, 10: $95-115$ for a discussion on the rise of emerging market MNEs using Brazilin MNEs as a case study.

${ }^{299}$ Folho de S.Paulo (2008). “Local Report: Lula Vai Levar Empresários ao Haiti Em Maio.” April 24, 2008. Accessed February 22, 2017. http://www1.folha.uol.com.br/fsp/brasil/fc2404200806.htm .

${ }^{300}$ Ibid.
} 
European Development Bank for the initial phase of Haitian road construction. ${ }^{301}$ Four years later, Folha de S.Paulo named OAS as a company that won a bid to construct the highway however later stopped construction. ${ }^{302}$ OAS claimed that it had completed $60 \%$ of the project, but halted construction because the Haitian government had not fulfilled its contraction obligations to expropriate the area resulting in USD $\$ 42$ in damages to resume construction. ${ }^{303}$ According to the news article, OAS was the only Brazilian company operating in Haiti in 2012. ${ }^{304}$

\section{Challenges for Engaging in the SSC Framework}

Twenty-four years transpired before Brazil and Haiti activated their SSC framework initiated in 1982. The framework became operative under the Lula administration in 2004. The departure of the U.S.-led Multinational Interim Force created an opportunity for Brazil to assume leadership of MINUSTAH, which is expected to continue through April 2017. The Lula administration prioritized Haiti over other countries in 2004, and Haiti received additional humanitarian assistance during periods of natural disasters (2010 earthquake, Hurricane Matthew). Despite that, as stated in the previous chapter, 106 out of 110 South-South cooperation projects between Brazil and

\footnotetext{
301 Ibid.

302 Machado (2012).

303 Ibid.

304 Ibid.
} 
Haiti are considered "complete," 305 with only one continuing through $2017 .{ }^{306}$ Evidence of a shift in Brazil's policy regarding South-South cooperation away from humanitarian and peacekeeping can be found in a speech given by Brazilian Ambassador Carlos Cozendey at the UN sponsored Third International Conference on Financing for Development in July 2015:

$[\ldots]$ we are moving from an agenda focused specifically on developing countries and their most pressing needs, to one of universal nature, applicable to all countries, rich or poor, and which seeks to address a much more comprehensive set of policy objectives, such as trade, industrialization and sustainable patterns of consumption and production. A pending but urgent task will be to align the UN development system to this more complex and sophisticated agenda, based on a universal approach instead of a donor-recipient mindset.

African countries currently are the main partners of Brazil in South-South cooperation. The Brazilian South-South technical cooperation has been developed with more than thirty-three African countries through bilateral channels, amounting to approximately USD\$57 million. The Brazilian Agency for

\footnotetext{
${ }^{305}$ Brazilian Ministry of Foreign Relations; Brazilian Cooperation Agency (2016)

${ }^{306}$ Brazilian Ministry of Foreign Affairs; Division of the Caribbean for Itamaraty, e-mail communication to author, "Subject: Cooperation Brazil-Haiti." October 5, 2016.
} 
Cooperation $(\mathrm{ABC})$ runs about a hundred and fifty projects and short-term initiatives in Africa. ${ }^{307}$

At no point during Ambassador Cozendey's speech did he mention Haiti or Brazil's longstanding leadership of the ongoing UN-sponsored peacekeeping operation in Haiti. Nevertheless, several participants stated that South-South cooperation and the SSC framework between Brazil and Haiti was no longer representative of the one envisioned under President Lula. One participant called the impeachment of President Dilma Roussef in 2016 an “institutional coup on Dilma” by the Brazil's ultra-conservative officials, thus signaling the end of South-South cooperation as traditional South-South cooperation. Brazilian firms' investments abroad thus indicate a much more pragmatic, economically driven SSC framework. According to the Global Humanitarian Assistance Report 2014, Brazil's international humanitarian assistance was among the top 10 donor decreases for 2013 at $-97 \% .^{308}$

Broadly speaking, the Brazil-Haiti framework of South-South cooperation has not developed independent of external actors; the overall findings indicate that the sustainability of the framework has been heavily dependent on who was president of Brazil (President Lula) and the policies of the governing party (PT). However, the Brazil-Haiti SSC framework has been active over the course that MINUSTAH has been

\footnotetext{
307 Cozendey, Carlos (July 2015). Statement by the Special Envoy of the President of the Federative Republic of Brazil, Ambassador Carlos Cozendey at the Plenary Session of the Third International Conference on Financing for Development. Addis Ababa, July 2015. Accessed February 23, 2017. http://www.un.org/esa/ffd/ffd3/wp-content/uploads/sites/2/2015/07/Brazil.pdf. ${ }^{308}$ Global Humanitarian Assistance (2014). Global Humanitarian Assistance Report 2014. Bristol: Global Humanitarian Assistance. Accessed March 13, 2017. http://www.globalhumanitarianassistance.org/wp-content/uploads/2014/09/GHA-Report-2014interactive.pdf.
} 
engaged in their peacekeeping operations. As mentioned by one of the study's participants, a larger diplomatic unit whose focus expanded beyond security-related concerns of Brazil's troops would have strengthened the SSC framework; however, "Brazilian ambassadors were [more] consumed with their military troops than the development." Even so, the main themes that emerged identified the challenges of the Brazil-Haiti SSC framework. For example, Haiti is disorganized, both countries suffer serious economic challenges, and both are afflicted by severe corruption.

Haiti is not an equal partner to Brazil, who is a MIC in terms of development and resources. Haiti is regarded as a fragile state and consequently exhibit characteristics of a country with challenges to governance. ${ }^{309}$ Though Brazil has extensive development cooperation with other LICs, particularly on the continent of Africa in Guinea-Bissau and Mozambique, there was the added cultural and language advantage of sharing the same Portuguese colonizer and language not present in a Brazil-Haiti framework. In several interviews and survey responses, participants spoke to similar histories and cultures, but did not address the significance of different colonizers and language as factor that could affect the Brazil-Haiti SSC framework. It was not clear for one respondent that SSC frameworks in fact exhibit fairness for visibly black populations. Consequently, it is not apparent from the qualitative findings or the literature that Haiti is able to engage in a SSC framework with another country who is a MIC, such as Brazil, where outcomes on development could ensue that are mutually beneficial. The theme of "Haiti is

\footnotetext{
${ }^{309}$ Heine and Thompson (2011).
} 
disorganized" was supported by examples of a lack of coordination, communication, and resources to fully engage in the SSC framework.

The political and economic situation in Haiti presented an opportunity for Brazil to signal and project a positive image of the country as a regional leader and global player by capitalizing on its military might and its foreign policy that emphasizes international cooperation with strategic partners mainly in Latin America and the Portuguese-speaking countries of Africa. Yet, Brazil has yet to obtain a permanent seat on the UN Security Council, which calls into question its ability and efforts to reform and expand the UN Security Council membership beyond the current five permanent members: China, France, Russia, the United Kingdom, and the United States. On a state visit to India in 2009, U.S. president Barack Obama endorsed India's candidacy to a permanent seat on the UN Council, but did not do the same for Brazil the following year. The U.S.'s lack of endorsement of a permanent seat on the UN Security Council came after Brazil's June 2010 vote against a U.S. proposal to impose sanctions against Iran for its nuclear program. By August 2011, Celso Amorim, President Lula's former Minister of Foreign Relations - and one of the main articulators of Brazilian participation in the peacekeeping mission in Haiti-came to support the departure of Brazilian troops from Haiti as Minister of Defense under Brazilian President Dilma Rousseff. ${ }^{310}$

Among the questionnaire respondents, those who are primarily practitioners found the Brazil-Haiti SSC framework challenging for Brazil due to the country's economic and political challenges. These individuals have recent, on-the-ground experience

\footnotetext{
${ }^{310}$ O Globo (2011). "Na posse, Celso Amorim defende retirada de tropas brasileiras no Haiti." August 8, 2011. Acceessed February 15, 2017. http://g1.globo.com/jornal-nacional/noticia/2011/08/na-posse-celsoamorim-defende-retirada-de-tropas-brasileiras-no-haiti.html.
} 
implementing and evaluating development cooperation, thereby observing the problems Brazil and Haiti encounter while engaging in the SSC framework. In particular, Brazilian practitioners and scholar academics were direct in their statements that the SSC framework is challenging for Brazil and Haiti. Specifically, they stated that Brazil should be more pragmatic in its relations with other nations because Brazil does not have money to invest and develop other countries given the country's economic crisis. A Brazilianist summed up the challenging situation by stating, "Haiti is not of strategic importance to Brazil.”

Few academic scholars stated that the SSC framework is not challenging for Brazil despite political and economic crisis. Mentions included, "It is not challenging at all, Brazil embraces it with great enthusiasm" and, "South-South cooperation is not challenging for Brazil.” In the case of Haiti, all but one participant held the SSC framework as challenging. Principally, most of the study's participants regard the SSC framework as challenging for Brazil and Haiti.

\section{$\underline{\text { Strategic Plans for Engaging in the SSC Framework }}$}

Based on the study findings, part of Brazil's strategy in engaging in South-South cooperation was to increase the perception of its leadership in the South, while Haiti aimed to receive assistance for self-sufficiency. As in the study of decision-making in international relations in Afinotan (2014), Southern countries engaged in South-South cooperation because it is in their self-interest to do so, which was also the case with this study's qualitative findings on Brazil and Haiti. The findings revealed that the decisions 
of Brazil and Haiti to engage in South-South cooperation may be governed by national interests such as individual political and economic agendas.

The qualitative findings of this study revealed that Haiti's strategic plan in engaging in South-South cooperation involved the receipt of financial assistance, as well as technical assistance to gain greater self-sufficiency. Financial assistance contributed to Haitian attempts to sustain their current situation in Haiti, while technical assistance allowed Haitians at the local level to be trained for long-term benefits and greater selfsufficiency in the future. Training involved, but was not limited to, health professionals for the well-being of the Haitians, military personnel for security, and farmers for the sustainable development of agriculture. However, Brazilian military presence in Haiti through MINUSTAH has been perceived as an "occupying force" by some Haitians and study participants; this may have induced fear in civilians. As mentioned by a highranking Haitian government official and elected official, Haiti has been unsuccessful with garnering success with private sector investments by Brazilian companies. Dady Chery, a blog writer whose work was posted on the Canadian-based Global Research Centre for Research on Globalization website, characterized Haiti's "lead export" to Brazil as “overwhelmingly young, male, and educated" Haitian immigrants, somewhat reminiscent of slavery. ${ }^{311}$ Chery's conclusion was based on a report in $O$ Tempo on a 2014 survey requested by $\mathrm{CNIg}$ about the lives of 340 Haitian immigrants to Brazil. ${ }^{312}$

\footnotetext{
311 Chery, Dady (2015). Hati's Lead Export: Brazil's New Slaves.” Global Research Centre for Research on Globalization, December 19, 2015. Accessed February 25, 2017. http://www.globalresearch.ca/haitis-lead-export-brazils-new-slaves/5496837.

312 Mattos, Litza (December 2015). Minas Gerais Recebe 3.000 Imigrantes do Haiti por Ano.” O Tempo, May 17, 2014. Accessed on February 25, 2017. http://www.otempo.com.br/mobile/capa/mundo/minasgerais-recebe-3-000-imigrantes-do-haiti-por-ano-1.846891.
} 
In any case, the strategic plans of Brazil in engaging in South-South cooperation involved enhancing Brazil's leadership role, including the quest to secure a permanent seat on the UN Security Council. Despite having the status of a MIC, Brazil engages in South-South cooperation, and provides assistance for Haiti as an act of pursuing their national interest. However, Brazil and Haiti both have strategic national gains in the partnership. This finding is supported by Afinotan (2014), who views independent states as rational entities in which national decisions are governed by national interests. ${ }^{313}$

Closely aligned with the themes for Brazil's strategic plans for engaging in the SSC framework is the previously mentioned finding that the SSC framework is not only political in nature, but perceived as an easier framework to employ as Brazil seeks to promote its internationalization on a global stage. A permanent seat on the UN Security Council could lead to Brazil gaining greater diplomatic power, which could advance their own interests and priorities. According to Kenkel (2013), the effectiveness of Brazil's peacekeeping efforts in Haiti plays an important role in advancing Brazil's interests, ${ }^{314}$ most especially under the Lula Administration. A high-level consultant to the Haitian government commented that the SSC framework is governed by an adage, “"He who has the gold makes the rules.' Since Haiti has long experienced financial issues, Haiti is not necessarily fully sovereign in its decision-making."

For Brazil, it may not be difficult to exhibit leadership with a partner country in a socio-economic position of Haiti, and it has been in both countries' interest to cultivate a

\footnotetext{
${ }^{313}$ Afinotan (2014).

314 Kenkel, (2013), 103.
} 
partnership. Brazil investment in technical cooperation activities outside of its role and participation in MINUSTAH has been small scale relative to its capabilities in the area of technical cooperation. Yet, Brazil has experienced international recognition for its involvement in development cooperation in Haiti. As previously mentioned in Chapter 4, Brazil was the first country to make a contribution to the HRF. Brazil's support of the HRF with a financial donation illustrates Brazil's engagement with the global system through its financial support of a Haitian relief fund with direct ties to global, multilateral fund. Following the 2010 earthquake and Brazil's contribution, the country received accolades from the international community among which the World Bank Group President Robert B. Zoellick stated:

Many promises have been made in support of Haiti's reconstruction. Turning these into reality for the Haitian people is urgent. Brazil's has a long-standing history of friendship with Haiti and has provided critical support in peace-keeping and security efforts over the past years. Haiti and the international community will also benefit from Brazil's vast development experience in the planning and implementation of reconstruction. We all look forward to Brazil's contributions in shaping the HRF into an effective mechanism for investing in a more prosperous future for the Haitian people. ${ }^{315}$

\footnotetext{
${ }^{315}$ World Bank (2010). "Press Release: Brazil becomes the First Country to Country to Contribute to Haiti Reconstruction Fund." May 11, 2010. Accessed February 24, 2017. http://www.worldbank.org/en/news/press-release/2010/05/11/brazil-first-country-contribute-haitireconstruction-fund.
} 
The Bank president's sentiment is parallel with Burges's assessment of Brazilian leadership strategy. ${ }^{316}$ Brazil negotiates on behalf of other southern countries through multilateral institutions. ${ }^{317}$

Additionally, the structure of the HRF provides a context for Brazil to possibly assert its influence through its partnership with Haiti. The HRF Steering Committee receives proposals for HRF funding for projects in Haiti. Brazil is a member of the HRF Steering Committee that is made up two other countries - Haiti and Norway—and multilateral institutions that include the Inter-American Development Bank (IADB), the $\mathrm{UN}$, and the World Bank. The makeup of the committee is significant for Brazil in terms of its ability to influence decision-making regarding HRF project funding and approvals. Brazil is the only Southern country on the steering country besides Haiti, and is the only bilateral development provider other than Norway. This membership structure reduces competing voices at the table should other development providers had voting privileges regarding project approvals. Brazil also has the ability to submit proposals to the HRF for funding consideration, which it has done in the case of the Artibonite River Dam project; the funds were later approved and redirected. ${ }^{318}$ Thus, Brazil supports the conditions for the HRF as a valuable mechanism for supporting Haiti, as well as an opportunity to further its own interests. Brazil has demonstrated that as an emerging donor country, it can capitalize on its development experience and work within the existing international aid architecture.

\footnotetext{
${ }^{316}$ Burges (2012).

${ }^{317}$ Ibid.

${ }^{318}$ Haiti Reconstruction Fund (May 2014).
} 
In Chapter 4, a scholar-practitioner and Latin Americanist cited that Brazil's approach to development cooperation is creating a new space within the existing global architecture. The results of the current study indicated that bilateral initiatives between Brazil and Haiti, as well as Brazilian private sector investment in Haiti (or lack thereof), are interrupted before completion, and/or are relatively short-term or short-lived.

\section{ADDRESSING THE HYPOTHESIS}

The main hypothesis was that South-South cooperation affects development cooperation by strengthening, weakening or having no impact on development in Brazil and Haiti. To determine the direction of the hypothesized relationship, I analyzed the overall directionality of the responses of the study's participants in relation to each of the sub-questions. For the first sub-question, I analyzed the participants' responses within three distinct categories: (a) "outstanding" or "positive" regarding the benefits of Brazil and Haiti engaging in the SSC framework; (b) "abnormal" or "negative" from engaging in the SSC framework; and (c) "normal," "neutral," or "exhibits potential." The study's second sub-question also employed three categories of: (a) high, (b) low, and (c) neutral. The third sub-question followed the same pattern of the second sub-question.

The categories that include responses that were "neutral" were participant responses that lacked significant direction regarding the impact of current SSC framework on development between Brazil and Haiti. On the question of benefits, I added "exhibits potential" to capture the number of participants who opted to speak to the "potential" of SSC framework rather than the existing state of the SSC framework for Brazil and Haiti. Additionally, categories on benefits included "normal" and "abnormal." 
Abnormal was included because one respondent averred that outcomes that ensued from the SSC framework were not to be viewed as normal and that the SSC framework would likely discontinue with ongoing administration and policy shifts. "Normal," "neutral," and "exhibits potential" were grouped together because each does not reflect directionality on the current SSC framework. Figure 5 shows the result of the analysis on the direction of the participants' responses to the sub-questions. For example, the number " 5 " represents five participants who provided responses in a given direction.

\begin{tabular}{|c|c|c|c|}
\hline & \multicolumn{3}{|c|}{ Respondent Indications } \\
\hline & $\begin{array}{l}\text { Outstanding/ } \\
\text { Positive }\end{array}$ & $\begin{array}{l}\text { Abnormal/ } \\
\text { Negative }\end{array}$ & $\begin{array}{c}\text { Normal/ } \\
\text { Neutral/ } \\
\text { Exhibits Potential }\end{array}$ \\
\hline \multirow[t]{3}{*}{$\begin{array}{l}\text { How do Brazil and Haiti benefit } \\
\text { from engaging in the SSC } \\
\text { framework? }\end{array}$} & 5 & 1 & 9 \\
\hline & \multicolumn{3}{|c|}{ Respondent Indications } \\
\hline & High & Low & Neutral \\
\hline \multirow[t]{3}{*}{$\begin{array}{l}\text { How challenging is the SSC } \\
\text { framework for Brazil and Haiti? }\end{array}$} & 8 & 5 & 2 \\
\hline & \multicolumn{3}{|c|}{ Respondent Indications } \\
\hline & High & Low & Neutral \\
\hline $\begin{array}{l}\text { How is engaging in the SSC } \\
\text { framework strategic for both } \\
\text { Brazil and Haiti? }\end{array}$ & 3 & 4 & 8 \\
\hline
\end{tabular}

Figure 5. Directionality of the qualitative responses to the dissertation sub-questions.

In the next step, I combined the respondents' indications on the sub-questions to determine if South-South cooperation affects development cooperation by strengthening, weakening, or having no impact on development in Brazil and Haiti. I accomplished this by assigning a numerical strength to each of the outcomes from 0 to 9 . The outcomes 
were assigned in this manner because the maximum number of respondent indication in any category in Figure 5 was 9. Figure 6 show the direction of the indication assignments.

\begin{tabular}{|l|l|l|}
\hline \multicolumn{1}{|c|}{ Responses } & \multicolumn{1}{c|}{ Respondent Indications } & \multicolumn{1}{l|}{ Assigned Direction } \\
\hline$n=0-n=2$ & Abnormal, Negative, Low & Weaken \\
\hline$n=3-n=5$ & $\begin{array}{l}\text { Normal, Neutral, Exhibits } \\
\text { Potential }\end{array}$ & No impact \\
\hline$n=6-n=9$ & Outstanding/Positive/High & Strengthen \\
\hline
\end{tabular}

Figure 6. Indication assignment.

To explain the hypothesized relationship between South-South cooperation and development cooperation each of the sub-questions received an assigned direction based on the strength of the indications of the respondents. For the first sub-question, "How do Brazil and Haiti benefit from engaging in the SSC framework?" there was no impact. This indicates that participants did not find the SSC framework to be particularly impactful in either direction on the development of Brazil and Haiti. A counterfactual assessment of Haiti without the presence of MINUSTAH or Brazilian development cooperation could provide a useful point of comparison. In response to the second subquestion, "How challenging is the SSC framework for Brazil and Haiti?" participants' results were mixed regarding the challenge that the SSC framework presents for Brazil and Haiti. Half of the participants regarded the SSC framework as highly challenging, and the other half deemed the challenge of the SSC framework to be low or neutral for Brazil and Haiti. The findings of the study are thus inconclusive regarding how challenging the SSC framework is for Brazil and Haiti. In response to the third sub- 
question, "How is engaging in the SSC framework strategic for both Brazil and Haiti?" the results were also inconclusive. Half of the participants found that engaging in the SSC framework had no impact on development for Brazil and Haiti, and the other half of the participants held that the SSC framework was spilt between being highly strategic or not very strategic. Overall, South-South cooperation affects development cooperation in a way that is inconclusive because the study's respondents find that the SSC framework is both challenging in a way that is not highly beneficial or strategic for either country. I concluded from the outcomes that the impact of South-South cooperation on development between Brazil and Haiti is not necessarily dependent on the benefits or challenges of the SSC framework. These results call into question the strategic nature of the SSC framework. Figure 7 presents a graphic representation of the results and outcomes of addressing the hypothesis.

\begin{tabular}{|c|c|c|c|c|}
\hline Hypothesis & \multicolumn{4}{|c|}{$\begin{array}{l}\text { South-South cooperation affects development cooperation by } \\
\text { strengthening, weakening or having no impact on development in } \\
\text { Brazil and Haiti. }\end{array}$} \\
\hline \multirow{2}{*}{$\begin{array}{l}\text { Purpose of } \\
\text { the sub- } \\
\text { questions }\end{array}$} & \multicolumn{4}{|c|}{$\begin{array}{l}\text { To explain the hypothesized relationship between South-South } \\
\text { cooperation and development cooperation }\end{array}$} \\
\hline & & $\begin{array}{l}\text { How do Brazil } \\
\text { and Haiti benefit } \\
\text { from engaging } \\
\text { in the SSC } \\
\text { framework? }\end{array}$ & $\begin{array}{l}\text { How } \\
\text { challenging is } \\
\text { the SSC } \\
\text { framework for } \\
\text { Brazil and Haiti? }\end{array}$ & $\begin{array}{l}\text { How is engaging } \\
\text { in the SSC } \\
\text { framework } \\
\text { strategic for both } \\
\text { Brazil and Haiti? }\end{array}$ \\
\hline \multirow{3}{*}{ Directionality } & Strengthen & & & $\mathrm{X}$ \\
\hline & Weaken & & $\mathrm{X}$ & \\
\hline & No Impact & $X$ & $X$ & $X$ \\
\hline
\end{tabular}




\begin{tabular}{|c|l|}
\hline Outcome & $\begin{array}{l}\text { The impact of South-South cooperation on development between } \\
\text { Brazil and Haiti is not necessarily dependent on the benefits or } \\
\text { challenges of the SSC framework and calls into question the strategic } \\
\text { nature of the SSC framework. }\end{array}$ \\
\hline
\end{tabular}

Figure 7. Graphic representation addressing the hypothesis results and outcomes.

\section{ADDRESSING THE CENTRAL QUESTION}

The final task was to answer the central research question by connecting the study's overall contributions. The study's contributions include the findings from the explanatory framework (based upon South-South cooperation and development cooperation literatures) and the qualitative research.

\section{Contribution of the Exploratory Framework to Answering the Central Question}

The major findings of the Explanatory Framework can be encapsulated in prospects for an emerging donor challenge to the traditional aid architecture and the nature of South-South cooperation in Latin America. Emerging donors from the South are considered a challenge to the international aid architecture because they operate outside the traditional aid architecture, ${ }^{319}$ represent solidarity among emerging powers within multilateral fora, ${ }^{320}$ and by presenting the case for a more inclusive international architecture that considers the needs of Southern countries. ${ }^{321}$

\footnotetext{
319 Burges (2012); Abdenur and da Fonseca (2013)

${ }^{320}$ Fues, (2013)

${ }^{321}$ Abdenur and da Fonseca (2013); Gray, Kevin and Murphy, Craig (2013). "Introduction: Rising Powers and the Future of Global Governance." Third World Quarterly, 34(2).
} 
In the early 2000s, Global South countries became active agents in articulating the rhetoric of South-South cooperation, taking policy positions in multilateral forums and institutions and establishing new institutions (material and symbolic). Emerging economies and regional powers became vocal critics of global governance and sought to reform its structures through their collective action at the international level. Brazil is recognized as a spokesperson among and on behalf of Southern countries at multilateral fora as Brazil views itself as “development regional leader" in South America. ${ }^{322}$

South-South cooperation appeared to be more suitable for Southern countries, as the SSC framework gave precedence to the principles and approaches of the Southern countries. Kindornay and Samy (2012) wrote that the structures and institutions that deliver aid (international aid architecture) have been described as "dysfunctional and uncoordinated;" these authors questioned the legitimacy of these structures because the framework lacks recipient ownership. ${ }^{323}$ Northern countries tend to focus on "forecasting" and "aid effectiveness." 324

The emerging donor challenge to the traditional international aid architecture emerges from rise of the South economically and politically and driven by an ongoing need for political and economic and technological cooperation. ${ }^{325}$ Big developing economies such as Brazil, India, and China experienced rapid, high, and sustained

\footnotetext{
${ }^{322}$ Pinheiro and Gaio (2014), 9

${ }^{323}$ Kindornay and Sam (2012).

${ }^{324}$ Bry (2016).

${ }^{325}$ IBON International (2014).
} 
economic growth during the early $2000 \mathrm{~s}^{326}$ and were recognized for their pragmatic and innovative trade, investment, and development. ${ }^{327}$ Moreover, Bry (2016) noted that Southern countries aspired to break away from the traditional aid paradigm, especially with the South's lack of emphasis on an evaluation-based framework for their development cooperation. Southern countries were believed to aspire to establish an alternative model of development cooperation. ${ }^{328}$ The establishment of an alternative model may also explain why Brazil as a Southern donor engages in South-South cooperation. $^{329}$

Gore (2013) posited that projects under South-South cooperation provided more representative development cooperation than assistance from North-South relations. ${ }^{330}$ Brazil's approach to South-South cooperation is more pragmatic through its focus on "market friendly" and "self-interested" economic opportunities that may benefit their regional partners. ${ }^{331}$ According to Malacalza (2014), Brazil led the ABC countries with a neo-developmentalist diplomacy model of cooperation in Haiti following the 2010 earthquake. ${ }^{332}$ This model of development cooperation is characterized by public investment, development, energy, transportation, telecommunication, and housing

\footnotetext{
${ }^{326}$ OECD (2013).

${ }^{327}$ United Nations (2011); Malik (2013).

${ }^{328}$ Bry (2016).

${ }^{329}$ IBON International (2014).

${ }^{330}$ Gore (2013)

331 Burges (2007), 1344.

${ }^{332}$ Malacalza (2014).
} 
construction. ${ }^{333}$ Despite the ideological shift in inter-American relations that allowed engagement in UN peacekeeping activities in Haiti, Feldman et al. argued that the ABC countries missed an opportunity to distinguish its international development cooperation in Haiti. ${ }^{334}$ Brazil has pursued its national interest of enhancing leadership and has sought a seat in the UN Security Council. ${ }^{335}$ Vieira and Alden (2011) claimed that Brazil made progress in its leadership through investments in the provision of "regional public goods" as it seeks to influence regional politics. ${ }^{336}$ Exact figures on Brazilian cooperation do not exist due to the nature of its bilateral peacekeeping activities and incomplete or unreported aid and development cooperation. ${ }^{337}$

Rowlands (2012) found that Southern donors' norms and practices differ from donors that adhere to DAC-based development assistance. ${ }^{338}$ Following either Kenneth Waltz' view of international politics that states exist within an anarchic international system $^{339}$ (structure) or Alexander Wendt's "anarchy is what states make of it" 340 (process), Southern donor countries have not been made to report their development cooperation activities to traditional global institutions or adhere to the North's norms and

\footnotetext{
333 Ibid. 66-67.

${ }^{334}$ Feldman, et. al (2011), 11

335 Ekström and Alles (2012), 18; Nieto (2012), 166-69.

${ }^{336}$ Vieira and Alden, 513, 516

${ }^{337}$ OECD (2016).

${ }^{338}$ Rowlands, 2012

${ }^{339}$ Waltz, Kenneth N. (1979). Theory of International Politics. Boston, MA: McGraw-Hill. 79-106.

${ }^{340}$ Wendt, Alexander (1992). "Anarchy is What States Make of It: The Social Construction of Power Politics." International Organization, 46(2).
} 
practices. There are no incentives for Southern countries to follow the North in the capacity of development providers. ${ }^{341}$

Scholars in the literature on development cooperation have offered a continuum along which to view the possibility of emerging donors creating a new, more representative aid architecture to its impossibility. Quadir (2013) acknowledged the possibility of a more representative aid architecture if emerging donors focused on the needs of recipients. ${ }^{342}$ Burges (2012) suggested that emerging donors are not a threat if held to the same standards of OEC-DAC countries; ${ }^{343}$ while, Chin and Quadir (2012) asserted that it is not clear whether Southern donors are in fact that different from the North in their practices. ${ }^{344}$ Rowlands (2012) acknowledged that emerging donors can create a new paradigm that does not pose a threat to the traditional aid architecture due to the diversity of their paradigms and the heterogeneity of Southern donors. ${ }^{345}$ Gore (2013) offered the more optimistic analysis that the aid architecture is in the process of being replaced by a new development cooperation architecture that better reflects the complexity and diversity of the development cooperation landscape. ${ }^{346}$ Six (2009) outlined that development and the development cooperation paradigm is incompatible with non-Western donors' fundamental approach to development with new programs

\footnotetext{
${ }^{341}$ Sinha and Hubbard, (2012). 2.

${ }^{342}$ Quadir (2013), 321.

${ }^{343}$ Burges (2012), 226.

${ }^{344}$ Quadir (2012).

${ }^{345}$ Rowlands (2012). 630.

${ }^{346}$ Gore (2013), 769.
} 
such as China's “world development” paradigm. ${ }^{347}$ Six’s view of development cooperation aligned with Gosovic's (2016) suggestion that South-South cooperation needs updating in order to be more applicable to contemporary times. ${ }^{348}$

From the findings of the explanatory framework that examines the emerging donor challenge to the traditional aid architecture and the nature of South-South cooperation in Latin America as a contribution to answering the central question the following can be determined. First, Southern countries believe they are better equipped to help other Southern countries because they represent a diversity of perspectives and practices that may better assist recipient countries - as Southern countries, they have been where recipient countries are now in terms of development and are now middleincome countries. Second, Southern countries do not have the same restrictions as Northern donors on their development cooperation with other Southern countries in terms of OECD-DAC prescriptions and conditionalities-Northern institutions have been unsuccessful in getting Southern countries to adhere to Northern development practices which leaves out private sector financing, commercial interests and foreign direct investment. Third, Southern countries see South-South cooperation as an opportunity to pursue their individual national interests through the framework of South-South cooperation as an emerging donor —For Haiti, Southern countries have approached development cooperation primarily on an individual (or country)basis despite models and frameworks to the contrary (ie. $A B C, A L B A$ ).

\footnotetext{
${ }^{347}$ Clemons (2009), 1108-1109.

${ }^{348}$ Gosovic (2016).
} 


\section{Contribution of the Qualitative Findings to Answering the Central Question}

The first sub-question was, "How do Brazil and Haiti benefit from engaging in SouthSouth cooperation framework?” Although it may appear that Haiti has more to gain from engaging in the SSC framework, findings of this study revealed that both Haiti and Brazil received benefits from the SSC framework. Generally, the participants found that the partnership with Brazil provided Haiti with socioeconomic, military, and security development. Brazil has provided Haiti with approximately US\$500-510 million in assistance between 2004 and $2011^{349}$ and military and security development since Brazil became the leader of the UN Stabilization Mission in Haiti. Yet, the qualitative findings also revealed that Haiti could have benefited more in the SSC framework with Brazil, if Brazil had focused more on providing technical cooperation. Participants made only a few references to non-peacekeeping initiatives including humanitarian visas for Haitians. However, a number of participants spoke to the potential rather than the current reality of the SSC framework when discussing the benefits for Haiti. There was also the interesting sub-theme for Haiti, that Brazil's engagement was more beneficial for Brazil than Haiti. This sub-theme calls into question the nature of the mutual benefit of the Brazil-Haiti SSC framework.

Being a MIC, Brazil has been a donor and a recipient of development strategies; nonetheless, among the LAC countries, Brazil has gained a strong influence, specifically in Haiti. Brazil played a role in intervening with the Haitian government following the

\footnotetext{
${ }^{349}$ Kenkel (2013), 99.
} 
political upheaval surrounding President Jean-Bertrand Aristide. ${ }^{350}$ Following the review of the document by Marroni (2013) and Vazquez (2013), the Brazilian Cooperation Agency (ABC) supported the act of enhancing leadership practices in LDCs. Brazil also opened up opportunities for a new market and political power through its partnership with Haiti. Of note, has been Brazil's ability to exercise leadership in Haiti while at the same time promote its internationalization agenda, experiment with pacification methods in high crime areas of Haiti and develop a Brazilian way of peacekeeping.

The second sub-question was, "How challenging is SSC framework for Brazil and Haiti?" The results of the analysis revealed that the challenges for Haiti and Brazil in engaging in the SSC framework were the disorganization of Haiti, economic challenges, and government corruption. Northern countries that have been known to exploit Haiti have been the ones providing development, political and military aid. Researchers have noted that Haiti's international relations appeared to contribute to its development struggles. ${ }^{351}$ Abdenur and Da Fonseca (2015) pointed out that Northern countries and institutions continue to play a significant part in the South-South cooperation despite reductions in Northern aid to the Global South following the 2008 financial crises. The authors claimed that the North desired to hold influence over Southern donors and SouthSouth cooperation.

For Brazil, according the study's qualitative findings, challenges for the SSC framework have been attributed to the economic and political crisis surrounding the economy and political corruption. These were factors that were not present when Brazil

\footnotetext{
350 Vieira and Alden (2011).

${ }^{351}$ O'Connor et al. (2014); Ramachandran and Walz (2012).
} 
first began to prioritize SSC framework in 2004. Furthermore, half of the study's participants find the SSC framework challenging for Brazil and Haiti and that the framework lacks sustainability due to Brazil's economic crisis, the fact that President Lula is no longer in office as president and a shift in government policy in the area of South-South cooperation. However, other participants mainly regard the SSC framework as not challenging, at least not for Brazil. As mentioned previously, the Brazil-Haiti framework has not developed independent of external actors. These external actors include the UN-sponsored MINUSTAH (the North) which includes the support of other Southern countries who are also affiliated with the United Nations mission such as Argentina and Chile. Thus, Brazil's presence in Haiti may not be regarded as challenging when considering the role and presence of external actors that are from the North or whose presence in Haiti is supported by the North. Additionally, there has been evidence that Brazil has shifted away from South-South cooperation that prioritizes Haiti in government policy and peacekeeping operations through the UN. Both countries' challenges around Haiti's disorganization and their mutual challenges stemming from economic and political corruption may eventually question the sustainability of their framework.

The third sub-question was, "How is engaging in the SSC framework strategic for both Brazil and Haiti?" The results of the analysis revealed that there was a perceived strategic benefit for both Brazil and Haiti in engaging in a South-South bilateral cooperation. The findings indicated that Brazil and Haiti both have strategic national gains in the partnership. Based on the study findings, part of Brazil's strategy in engaging in South-South cooperation was to enhance its leadership in the Global South, 
while Haiti aimed to receive assistance for self-sufficiency. As in the study of Afinotan (2014), Southern countries engaged in South-South cooperation due to mutual national interests, as did Brazil and Haiti, based on the study findings. ${ }^{352}$

The findings of this study revealed that Haiti's strategic plan in engaging in South-South cooperation involved the receipt of financial assistance, as well as technical assistance. Financial assistance helped Haitians sustain the current situation in Haiti, while technical assistance allowed Haitians at the local level to be trained for long-term benefits and self-sufficiency in the future. Training involved, but were not limited to, health professionals for the well-being of the Haitians, military personnel for security, and farmers for the sustainable development of agriculture. As previously mentioned, Brazilian military presence in Haiti through MINUSTAH has not necessarily been viewed positively. ${ }^{353}$ Nevertheless, the strategic plans of Brazil in engaging in SouthSouth cooperation involved enhancing their leadership role, including the pursuit of securing a seat on the UN Security Council. To date, Brazil has not gained a permanent seat on the UN Security Council, and according to several of the study's participants, South-South cooperation is no longer a priority for Brazil. Despite being a middle income country, Brazil therefore engaged in South-South cooperation and provided assistance for Haiti as an act of pursuing their national interest.

\footnotetext{
352 Afinotan (2014).

${ }^{353}$ Lemay-Hebert, Nicolas (2015). "United Nations Stabilisation Mission in Haiti (MINUSTAH)" in The Oxford Handbook of United Nations Peacekeeping Operations edited by Joachim Koops, Norrie MacQueen, Thierry Tardy, and Paul D. Williams, Oxford: Oxford University Press, 727.; Muggah, Robert (2010). "The Effects of Stabilisation on Humanitarian Action in Haiti." Disasters, 34(53): 5446-5447.
} 
The major contribution of the qualitative findings to answering the central question is two-fold. First, the impact of Brazilian assistance to Haiti is highly conditioned upon each country's relationship to the North. Second, changes in the political and economic conditions of Brazil as the development cooperation provider affects the SSC framew ork.

\section{Overall Results of the Study's Contributions}

The findings of the study conclude that South-South cooperation is an alternative to North-South cooperation. Southern countries believe they are better equipped to help other Southern countries because they represent a diversity of perspectives and practices that may better assist recipient countries. Southern countries do not have the same restrictions as Northern donors on their development cooperation with other Southern countries in terms of OECD-DAC prescriptions and conditionalities. Southern countries see South-South cooperation as an opportunity to pursue their individual national interests through the framework of South-South cooperation as an emerging donor. The contributions of the explanatory framework and qualitative research leads to a two-prong answer to the central question Why Southern countries engage in South-South cooperation?: (1) a SSC framework between two Southern countries may serve as an alternative to North-South cooperation despite remaining highly conditioned by the Northern-dominated international system of governance such as the United Nations MINUSTAH peacekeeping operation in the case of Brazil and Haiti and (2) the SSC framework is primarily driven by emerging donor countries in a MIC-LIC context. Thus, changes in the political and economic conditions of emerging donor countries have great 
potential for destabilizing the sustainability of SSC frameworks. With regard to Southern development providers, it appears they do not encounter impunity from the international system for their role in the lack of sustainability of SSC frameworks, and recipients have little recourse. Figure 8 shows a graphic representation that addresses the central question and includes the overall results of the study's contributions.

\begin{tabular}{|c|c|c|}
\hline $\begin{array}{c}\text { Central } \\
\text { Research } \\
\text { Question }\end{array}$ & \multicolumn{2}{|c|}{ Why Southern countries engage in South-South cooperation? } \\
\hline $\begin{array}{c}\text { Study } \\
\text { Contributions }\end{array}$ & \begin{tabular}{l}
\multicolumn{1}{c}{ Findings of the Explanatory } \\
\multicolumn{1}{c}{ Framework } \\
-literature \\
(1) Southern countries believe they \\
are better equipped to help other \\
Southern countries because they \\
represent a diversity of perspectives \\
and practices that may better assist \\
recipient countries \\
(2) Southern countries do not have \\
the same restrictions as Northern \\
donors on their development \\
cooperation with other Southern \\
countries in terms of OECD-DAC \\
prescriptions and conditionalities \\
(3) Southern countries see South- \\
South cooperation as an \\
opportunity to pursue their \\
individual national interests through \\
the framework of South-South \\
cooperation as an emerging donor
\end{tabular} & \begin{tabular}{l}
\multicolumn{1}{c}{ Findings of the } \\
Qualitative Research \\
-in-depth interviews \\
-survey questionnaire \\
-data sources \\
(1) The impact of \\
Brazilian assistance to \\
Haiti is highly conditioned \\
upon each country's \\
relationship to the North \\
(2) Changes in the \\
political and economic \\
conditions of Brazil as the \\
development cooperation \\
provider impacts the SSC \\
framework
\end{tabular} \\
\hline \multicolumn{3}{|c|}{$\begin{array}{l}\text { Overall Results of the Study's Contributions } \\
\text { zork between two Southern countries may serve as an alternative } \\
\text { operation however remain highly conditioned by the Northern- } \\
\text { tional system of governance such as the United Nations } \\
\text { ekeeping operation in the case of Brazil and Haiti }\end{array}$} \\
\hline
\end{tabular}


(2) The SSC framework is primarily driven by emerging donor countries in a MIC- LIC context.

Changes in the political and economic conditions of the emerging donor country has great potential for destabilizing the sustainability of the SSC framework without much impunity for the Southern development providers by way of the international system and little recourse for the recipient country.

Figure 8. Graphic representation addressing the central question.

The chapter opens with the title "A South-South Solution" which suggests that South-South cooperation provides a solution for Southern countries, however, one that is complex. In the case of Brazil and Haiti who represent a MIC and LIC, the role of the North must be considered. South-South cooperation at its inception, embraces the presence of the North and for emerging donors, the opportunity to extend its influence beyond its region and onto an international stage. The next chapter looks at the study's contributions for rethinking development cooperation and directions for future study. 


\section{CHAPTER 6}

\section{CONCLUSION}

"Everyone needs a little help on the way to becoming self-reliant." Tupac Amaru Shakur; an American rapper and hip-hop artist, MTV News, $1992^{354}$

\section{INTRODUCTION}

\section{Task and Synopsis of the Study}

The overall task of this study was to examine South-South cooperation as an alternative development strategy in LAC in the wake of declining aid from the Global North to the Global South. The general problem was that as an economic and political framework, South-South cooperation has not produced the empirical support of that of the prevailing North-South framework. The central research question was, "Why Southern countries engage in South-South cooperation?" The question of why is important given the history of political and economic crisis in developing countries including those that are currently middle income. Therefore, the purpose of this qualitative case study was to examine this problem through the Brazil-Haiti SSC framework. I accomplished this by analyzing the impact through the benefits, challenges and strategic rationale of their SSC framework.

The study was guided by the fundamental idea that national interests drive development cooperation between and on behalf of states in the South; thus, states are motivated by their national interests when making decisions and creating policies within

\footnotetext{
${ }^{354}$ Shakur, Tupac Amaru (1992). "Tupac Calls Out Trump's Greed in this Unseen 1992 MTV Interview.” Accessed February 10, 2017. http://www.mtv.com/news/2870384/tupac-calls-out-trumps-greed-in-thisunseen-1992-mtv-interview/.
} 
a SSC framework. I expected that the self-interests of Southern states would explain the existence of South-South cooperation as opposed to strict ideological considerations on solidarity or ethical responsibility.

In order to examine the benefits, challenges and strategic plans for Brazil and Haiti's engagement in development cooperation, three research sub-questions guided the dissertation study. Specifically, the sub-questions sought to determine the nature of the Brazil-Haiti framework of cooperation from the perspectives of high-ranking officials and subject matter experts on South-South cooperation between Brazil and Haiti. Additional data collected included newspapers, government documents, speeches, and press releases to further collaborate, support, and contextualize the relationship between Brazil and Haiti.

Among the study's participants were high-ranking officials in the governments of Brazil and Haiti, including current and former advisors, consultants, political appointees, cabinet members, and diplomats, as well as experts affiliated with the World Bank, U.S. government officials, and USAID contractors. They have been involved in commenting on, setting the agenda, decision-making, and implementing South-South cooperation in general and in Brazil and Haiti. I chose these elite respondents because they have acted on behalf of the state or in the case of academics possess in-depth expert knowledge of South-South cooperation in the region.

Overall, as a subject of study, each case country benefited from their engagement in South-South cooperation. However, the ways in which they each benefited differed and the likelihood of subsequent benefit for either country was questionable given present and ongoing shifts in presidential policy and party. The second sub-question focused on 
examining how challenging the SSC framework is for Brazil and Haiti. Both countries share a similar set of challenges for their engagement in the SSC framework. Those challenges shape the attributes of their partnership and the sustainability of the SSC framework. The third sub-question looked at the strategic reasoning for each country's engagement in South-South cooperation. According to the qualitative findings, the strategy for cultivating a partnership stemmed from Brazil's need to strengthen its position as a leader in the South through technical cooperation and peacekeeping and for Haiti to become more self-sufficient in the areas they received technical cooperation and peacekeeping from Brazil- namely military and security assistance.

I understood that countries in the South engage in South-South cooperation, not mainly because of a shared mutual national interest by way of the SSC framework, as proposed in Chapter 1, or because of a shared mutual benefit, as espoused under the principles of South-South cooperation. Each country's political landscape vis-à-vis the North drives their SSC framework, as evidenced by the number of participants who connect the Brazil-Haiti SSC framework to Brazil's quest for a permanent UN Security Council seat; Haiti's overwhelming need for "military and security" benefits following the political crisis surrounding President Aristide; and need for additional assistance from the UN supported MINUSTAH led by Brazil following the 2010 earthquake.

Though I expected that the self-interests of Southern states would explain the nature of their development cooperation, each country's political relationship with the North were also an intervening factor in their SSC framework. An imminent threat to the future of the Brazil-Haiti SSC framework points to Brazil's shifting priorities amid political crisis and economic recession and the probable end of MINUSTAH or change in 
country leadership of the peacekeeping operation in Haiti by April 2017. ${ }^{355}$ Haiti remains a low income, low development country in terms of country risk; however, political and economic changes in Brazil present another intervening factor that challenges the BrazilHaiti SSC framework.

I also hypothesized in Chapter 1 that the South-South cooperation framework affects development by strengthening development cooperation because the framework considers factors outside the scope of domestic conditions. In the case of Brazil and Haiti, the outcome was inconclusive given that the impact of South-South cooperation on development between the two countries is not necessarily dependent on the benefits or challenges of the SSC framework. This outcome ties into the findings of the explanatory framework in a similarly inconclusive way. Southern countries believe that as development partners, they are better positioned to help other Southern countries with a Southern brand of development cooperation. Yet, these same countries seek their individual national interests. Thus, outcomes of the hypothesis and findings of the explanatory framework are both inconclusive and suggest that South-South cooperation as a development model is not straight forward.

Two overarching themes emerged from the contributions of the dissertation study: (a) the intervening influence of the Northern-dominated international system of governance on the Brazil-Haiti SSC framework and (b) uncertain political and economic future of Brazil. The findings of the study concluded that South-South cooperation is an alternative to North-South cooperation, however; the impact of Brazilian assistance to

\footnotetext{
355 United Nations Security Council (2016). "Resolution 2313, The Question Concerning Haiti," Adopted by the Security Council at its $7790^{\text {th }}$ meeting on October 13, 2016. Accessed December 14, 2016. http://unscr.com/en/resolutions/2313.
} 
Haiti is highly conditioned upon each country's relationship to the North and changes in the political and economic conditions of Brazil as the development cooperation provider.

The goal of this chapter is to offer a political analysis of the impact of Brazil's assistance to Haiti since 2004, as well as a prognosis for the sustainability of the SSC framework for LICs in similar development situations to Haiti in need of international development cooperation. I begin by tracing ways to rethink development cooperation in Latin America through the Brazil-Haiti case, followed by an evaluation of the potential impact of current international developments on the prospects for South-South cooperation for countries in the Global South. The chapter concludes with recommendations for further research and conclusion.

\section{RETHINKING DEVELOPMENT COOPERATION}

Brazil is a BRIC country that considers itself a global player. ${ }^{356}$ At the time Brazil promulgated its technical cooperation agreement with Haiti and assumed leadership of the UN peacekeeping operations in 2004, the country had a strong economy, sizable military and a president willing to make Haiti a priority development partner above its traditional Latin American and Portuguese-speaking African country partners in terms of monetary and human resource investment. Haiti became a benefactor of sustained Brazilian technical cooperation after Brazil assumed leadership of the UNsponsored peacekeeping operation MINUSTAH. Brazil's motivation for assuming leadership of MINUSTAH has been strongly linked to its desire to obtain a permanent

\footnotetext{
${ }^{356}$ Dauvergne and Farias (2012); de Freitas Santos and Cerqueira (2014); Christensen, Steen Fryba (2013). "Brazil’s Foreign Policy Priorities." Third World Quarterly, 34(2).
} 
seat on the UN Security Council. Japan is the only country that has served more often than Brazil as a non-permanent member of the Security Council. ${ }^{357}$

The primary challenge for Haiti is that it only became a benefactor of sustained Brazilian technical cooperation after Brazil assumed leadership of the UN-sponsored peacekeeping operation MINUSTAH. This position signals that Haiti's relationship may be highly dependent upon the presence of the Brazilian-led peacekeeping operation sponsored the UN (a Northern multilateral institution). In tangible terms, Haiti has offered Brazil a platform to exercise its regional and global leadership aspirations and promote its internationalization including Brazilian multinational enterprises. Haiti developed an international development strategy in tandem with the North through the establishment of the HRF, of which Brazil is the only other country member from the South. As an international development strategy, Haiti promotes a policy of a friendly business climate and openly encourage foreign investments as key to its economic recovery. The findings of this study suggested that Brazil has been less than enthusiastic about capitalizing on Haiti's willingness to engage in significant, sustained investments. A study participant suggested that Brazil is not willing to compete with other countries with longstanding interests in Haiti such as the United States, the Dominican Republic, and France. On the same question, another participant commented on Brazil's dominance in the region, but not specifically in regards to Haiti. As a result of the Brazil and Haiti's SSC framework, several lessons can inform thinking on South-South cooperation as an alternative development strategy for Southern countries.

\footnotetext{
357 Sotamayor Velazquez, Arturo (2013). "Democratization and Commitment to Peace: South America's Motivation to Contribute to Peace Operations" in South America and Peace Operations: Coming of Age edited by Kai Michael Kenkel, London and New York: Routledge, 45-63.
} 


\section{Brazilian Involvement in Haiti}

Brazilian involvement in Haiti has been largely associated with its leadership of MINUSTAH and the expansion of South-South cooperation as a matter of foreign policy under President Lula and the early years of the President Dilma's administration.

Brazilian participation in peace operations in Haiti is decidedly different from that of its previous operations that have been labeled "token contributions." 358 Brazilian generals have held the role of Force Commander leader for the entire duration of the MINUSTAH mission, as well as the largest allotment of troops. Given the size and scope of Brazilian economic and political capabilities relative to other developing country contributions, their overall peacekeeping contribution could be considered modest when it is reported that Bangladesh, Ethiopia, India, Pakistan, and Rwanda are the top five contributors of troops and police forces to UN peacekeeping missions. ${ }^{359}$

Brazil had minimal technical cooperation with Haiti prior to its leadership of MINUSTAH, a multilateral approach to engagement with the country. Brazil and Haiti signed the Basic Agreement on Technical and Scientific Cooperation on October 15, 1982. The two countries did not formally begin technical cooperation in earnest until November 24, 2004, when the agreement was formally signed into law. The signing of the agreement into law in 2004 represents a 22-year difference between the initial agreement and 5 months after Brazil assumed leadership of MINUSTAH. For the years

\footnotetext{
358 According to Katharina Coleman, the term "token contributions" signifies small contingencies of military observers, staff officers and liaison officer cited by Kenkel (2013), 98.

${ }^{359}$ Reuters (September 2015). “Countries Pledge 40,000 U.N. Peacekeepers at U.N. Summit." September 28, 2015. Accessed December 27, 2017. http://www.reuters.com/article/us-un-assembly-peacekeepersidUSKCNORS2E420150929.
} 
2000-2014, the Ministry of Foreign Relations online database documented 110 SouthSouth cooperation projects with Haiti; all but four have been marked complete. ${ }^{360}$ In addition, the Brazilian Ministry of Foreign Affairs Division of the Caribbean for Itamaraty stated that two bilateral projects have been scheduled for 2016, with only one continuing through 2017, as of October 5, 2016. ${ }^{361}$ Overall, there has been a decline in the levels of technical and humanitarian cooperation between Brazil and Haiti following a high of 16 projects after the January 2010 earthquake. ${ }^{362}$

Brazil had minimal technical cooperation with Haiti prior to 2004, and its assistance has steadily declined since 2010 . Whether Haiti will retain its priority status with Brazil will be determined once Brazilian-led leadership of MINUSTAH has occurred. Brazil's bilateral cooperation with Haiti has been strongly linked to its multilateral activities with Haiti. Thus, Brazilian involvement in Haiti is not as robust as it has appears given the role and participation of MINUSTAH.

\section{Relying on the UN Sponsored Peacekeeping for Development is Problematic}

The UN Security Council between 2004 and 2016 has adopted 16 resolutions on the mandate of MINUSTAH. For nearly 5 years, the UN Security Council has sought to scale back its operations in Haiti. Resolution 2070 (2012) began the process of drawing

\footnotetext{
${ }^{360}$ Brazilian Ministry of Foreign Relations; Brazilian Cooperation Agency (2016).

${ }^{361}$ Brazilian Ministry of Foreign Affairs; Division of the Caribbean for Itamaraty, e-mail communication to author.

${ }^{362}$ Brazilian Secretariat of Strategic Affairs of the Presidency of the Republic (2014). "Brazilian Cooperation for International Development 2010." Institute for Applied Economic Research (IPEA), 75.
} 
down MINUSTAH troops with the withdrawal of infantry and engineering personnel. ${ }^{363}$ Three years later, Resolution 2243 (2015) affirmed the "possible" withdrawal of MINUSTAH and "transition" to a future United Nations presence in Haiti after October 15, 2016. ${ }^{364}$ The UN Security Council reaffirmed the same intent the following year with Resolution 2313 (2016). ${ }^{365}$ The Council moved forward with its intent to draw down troops, despite Haiti experiencing significant electoral challenges resulting in delays and postponements of the presidential runoffs between December 2015 and October 2016, the resignation of the president without a replacement in February 2016, and Category 4 Hurricane Matthew on October 4, 2016. Resolution 2313 (2016) extended MINSTAH operations through April 15, 2017, pending review of the security and stability context. ${ }^{366}$ Thus, intentions for the full withdrawal of MINUSTAH have been underway since 2015; this signals that Haiti's ongoing and long-standing development challenges are not a necessary justification for the continued presence of the MINUSTAH mission and Brazilian leadership.

Resolution 2313 (2016), which articulates the most current MINUSATAH mandate, affirms the existence of numerous, ongoing development challenges in Haiti. The acknowledged challenges include: (a) the Haitian National Police lack of

\footnotetext{
${ }^{363}$ United Nations Security Council (2012). "Resolution 2070," Adopted by the Security Council at its $6845^{\text {th }}$ Meeting, on October 12, 2012. Accessed on December 14, 2016. http://www.un.org/en/ga/search/view_doc.asp?symbol=S/RES/2070(2012).

${ }^{364}$ United Nations Security Council (2015). "Resolution 2243 (2015)," Adopted by the Security Council at its $7534^{\text {th }}$ Meeting, on October 14, 2015. Accessed on December 14, 2016. http://www.un.org/en/peacekeeping/documents/minustahres2243.pdf.

${ }^{365}$ United Nations Security Council (2016).

${ }^{366}$ Ibid.
} 
independence and need for international support; ${ }^{367}$ (b) significant humanitarian and state capacity challenges, which include drought and food insecurity that impacts 1.5 million people; (c) an increase in suspected cases of cholera and cholera-related deaths; ${ }^{368}$ (d) substantial problems with sexual and gender-based violence, ${ }^{369}$ and (e) failure by the Haitian government to assign a ministry to oversee human rights and lack of progress by the judicial authorities to investigate and prosecute crimes of serious human rights and violations. ${ }^{370}$ The combination of social inequality, inflation, insufficient investment, political uncertainty, and lack of transparent and effective governance systems are believed to negatively impact development and the implementation of the Strategic Development Plan of Haiti. ${ }^{371}$

Noting with concern the slow progress towards consolidating the rule of law and calling on the Haitian Government to address the deficiencies in the justice and corrections systems, prolonged pretrial detention, prison overcrowding, widespread corruption, and denial of human rights including fair trial guarantees[.] ${ }^{372}$

\footnotetext{
${ }^{367}$ Ibid. 2.

368 Ibid. 3.

${ }^{369}$ Ibid. 4.

${ }^{370}$ Ibid.

${ }^{371}$ Ibid.

${ }^{372}$ Ibid. 4.
} 
Issues around rule of law, justice, corrections systems, and human rights date back to the initial resolution establishing MINUSTAH. These have remained priority concerns over the course of the UN mission in Haiti.

\section{Contested Domestic Support within Brazil}

Prior to MINUSTAH, the UN authorized five UN missions led by non-Latin American or Caribbean countries around stability, security, elections, human rights, and one observer group since the early 1990s. A noted difference is Brazilian leadership and troop contribution. ${ }^{373}$ Since 1947, Brazil has taken part in UN peacekeeping missions under Chapter VI peacekeeping provisions, including the Organization of American States' sponsored Inter-American Peace Force in the Dominican Republic in 1965. From the start of Brazil's engagement in Haiti in 2004 through the UN peacekeeping mission, however, domestic actors have debated the legitimacy of Brazilian involvement in MINUSTAH under Chapter VII. MINUSTAH's Chapter VII reference to a peace enforcement mandate runs counter to Brazil's historical principle of non-interventionism in the internal affairs of foreign countries. Brazil has repeatedly sought to withdraw its peacekeeping forces from Haiti. The failure to achieve a permanent seat on the U.S. Security Council and long-debated issues of legitimacy within the country concerning Brazilian involvement in Haiti contribute to the weakness of the Brazil-Haiti SSC framework prior to Brazil's political and economic crisis, despite benefits each country has received.

${ }^{373}$ Kenkel (2014). 


\section{Conclusion: South-South Cooperation is Dead or Haiti is No Longer a Priority}

If one views Brazil's South-South cooperation framework similarly to that of its economy, one can observe boom and bust cycles. Specifically, one can recognize a relationship with Haiti characterized by ups and downs as reflective of the spending cycles before and after natural disasters instead of a balanced occurrence. Key factors include the state of the economy, presidential will, and political crises. Brazil has predicated its foreign policy on development cooperation and success in South-South cooperation on a foundation of helping the poor. Brazil was able to capture domestic success around social programs such as Bolsa Familia and experiment with their security measures, thus creating a security-development nexus.

The findings of the current study contributed to the idea that the decisions of each independent state — at least in theory — are governed by motives for their national interest. Brazil and Haiti's engagement in South-South cooperation was believed to be fueled by national motives ${ }^{374}$ as they pursued their political and economic interests. This study is significant in addressing the South-South relationship of Brazil and Haiti. Findings in this study suggested that both Brazil and Haiti both had received benefits from engaging in the SSC framework; however, some Haitian leaders, officials, and scholar-practitioners perceived that despite Haiti having received assistance through development projects and plans from Brazil, Brazil had more to gain politically and economically from the partnership with Haiti. Brazil may no longer seek the same national interests as it did in 2004. Brazil may no longer seek the same national interests around pursuing a

\footnotetext{
${ }^{374}$ Afinotan (2014)
} 
permanent UN Security Council seat through the Brazil-Haiti SSC framework. More importantly, a political analysis of the findings led me to reconcile this view with the summation by two of the study's respondents: (a) Haiti is not a priority, and (b) Brazil's South-South cooperation (at least with Haiti) is dead. Scholars may use these findings to enhance future policies and agreements between the two countries and to clarify the feasibility of other SSC frameworks and relationships with similar political and economic circumstances.

\section{DIRECTIONS FOR FUTURE STUDY}

Without a renewed commitment from Brazil as an emerging donor from the South and isolationist thinking prevalent among major powers, ${ }^{375}$ Haiti and other LICs will need to look to the skills gained through the years as recipients with traditional and now emerging donors and perhaps pursue other non-traditional providers. ${ }^{376}$ With this understanding, possible directions for future research from the contributions of the study can be made. First, a study exploring the perspectives of Global South leaders and officials representing the countries that provided the highest levels of humanitarian assistance after the 2010 earthquake may be explored to gain greater insight into the limitations that national interests play in contributing to Haiti and other LICs. Second, researchers could consider a comparative study of development cooperation initiatives

\footnotetext{
${ }^{375}$ New York Times (2017). “Mr. Trump’s Island Mentality.” Sunday Review. March 5, 2017, 166(57527): 12. Accessed March 27, 2017. https://www.nytimes.com/2017/03/04/opinion/sunday/president-trumps-island-mentality.html?_r=0; Hunt, Alex and Wheeler, Brian (2017). "Brexit: All You Need to Know about the UK Leaving the EU." BBC News. Accessed March 27, 2017. http://www.bbc.com/news/uk-politics-32810887

376 The Middle East has a long history of regional development cooperation and contributors to Haitian relief following the 2010 earthquake. See Smith (2011).
} 
that have been undertaken in tandem with other stakeholders known as trilateral cooperation with a single recipient country. Third, the methodology employed in this study may be replicated in the understanding of the development strategies of other Global South countries engaged in South-South cooperation. Understanding the benefits, challenges, and strategies of other Global South countries engaging in the South-South cooperation could contribute to a more in-depth understanding of why Southern country choose to engage in South-South cooperation. Fourth, further in-depth analysis of the strategic plans of Haiti and Brazil in engaging in South-South cooperation may be examined once MINUSTAH has withdrawn peacekeeping operations in Haiti. A central question under study could include whether Brazil will return to its pre-2004 levels of cooperation (which was minimal), remain the same, or become more robust. Lastly, a study could encompass the perspectives of Haitian humanitarian agencies and nongovernment organizations, the police, representatives from the agricultural sector, and the infrastructure development sector, as the mentioned stakeholders appear to be directly affected by the assistance from Brazil.

\section{CONCLUSION}

In this study, I sought to examine South-South cooperation as an alternative development strategy in an era characterized by reductions in aid from the Global North to the Global South. I accomplished this goal by examining the SSC framework between Brazil and Haiti with the expectation that their cooperation would be motivated by achieving mutual national interest within their development cooperation framework when creating policy and entering agreements. It was expected that Brazil and Haiti's self- 
interest as Southern states would explain the nature of their development cooperation; however, each country's political relationship with the North were also an intervening factor in their SSC framework. South-South cooperation has been making a breakthrough in the development strategies of Southern countries; however, little is known from the SSC framework. ${ }^{377}$ Brazil and Haiti share some similar political history and culture, and as a result may fit their countries' development strategies within the SSC framework better than in the North-South relationship. ${ }^{378}$

The findings of this study revealed that both Brazil and Haiti benefitted from South-South cooperation. While Haiti generally received assistance, Brazil increased political power and the opportunity for new markets in the partnership. Yet, the study's participants did not find SSC framework particularly impactful on the development of Brazil and Haiti with Brazil gaining more their collaboration than Haiti. The findings were inclusive with regard to how challenging the SSC framework is for Brazil and Haiti. Half of the study's participants found the framework "highly challenging" and the other half "low or neutral" in terms of a challenge for Brazil and Haiti. Strategically, Brazil and Haiti aim to gain development from engaging in the SSC framework, whereby Brazil aims to gain political power in the South, while Haiti aims to achieve sustainable development. The findings were also inconclusive on the strategic nature of the SSC framework. Half of the study's participant did not hold that engaging in the SSC framework as impactful for Brazil and Haiti. The other half of the participants were

\footnotetext{
${ }^{377}$ Dreher, et al. (20110; Gray and Gills (2016).

${ }^{378}$ Baranyi, et al. (2015).
} 
divided between finding the SSC framework as highly strategic or not very strategic (low).

Themes emerging from the findings contribute to an understanding of the intervening nature of the international system of governance on the SSC framework for both Brazil and Haiti, including the quality of their benefits, the nature of their challenges, and the strategies they employ in their development cooperation. More pointedly, shifts in the political and economic conditions in emerging donor country should be considered a marker that governs the sustainability of the SSC framework despite the alternative nature of South-South cooperation. Presenting a "South-South solution" as an alternative to North-South cooperation does not imply immunity from the North, markets or other destabilizing influences. 


\section{REFERENCES}

Abdenur, Adriana Erthal and Marques Da Fonseca, João Moura Estevão (2013). "The North's Growing Role in South-South Cooperation: Keeping the Foothold." Third World Quarterly, 34(8): 1475-1491.

Abdenur, Adriana. Erthal and De Souza Neto, Danilo Marcondes (2014). "Rising Powers and the Security-Development Nexus: Brazil's Engagement with Guinea-Bissau." Journal of Peacebuilding \& Development, 9(2): 1-16.

Afinotan, L. Andy (2014). "Decision-making in International Relations: A Theoretical Analysis." Canadian Social Science, 10(5): 249-256.

Amar, Paul (2012). Global South to the Rescue: Emerging Humanitarian Superpowers and Globalizing Rescue Industries. New York: Routledge.

Baranyi, Stephen, Feldmann, Andreas E. and Bernier, Lydia (2015). "Solidarity Forever? ABC, ALBA and South-South Cooperation in Haiti." Third World Quarterly, 36(1): 162-178.

Baron, Mark A. (2008). Guidelines for Writing Research Proposals and Dissertations. Division of Educational Administration: University of South Dakota, 1-52.

Beckett, Greg (2013). "Rethinking the Haitian Crises." in The Idea of Haiti: Rethinking Crises and Development. Edited by Millery Polyné. University of Minnesota Press. 27-49.

Beeby, C. E. (1992). “The Biography of an Idea: Beeby on Education.” Wellington (N.Z): Council of Educational Research, as cited on the UNESCO webpage. Accessed November 24, 2014. http://www.unesco.org/education/educprog/50y/brochure/aid/226.htm

Belgrade Declaration of Non-Aligned Countries, 1961 (Excerpts) (n.d.). Accessed October 20, 2015. http://pustakahpi.kemlu.go.id/dir_dok/01st\%20Summit\%20of\%20the\%20NonAligned\%20Movement\%20\%20Final\%20Document\%20(Belgrade_Declaration).pdf

Betancourt, María Clara Sanín and Schultz, Nils-Sjard (2009). "South-South Cooperation in Latina America and the Caribbean: Ways ahead following Accra." FRIDE. March 2009, 2.

Bilal, Sanoussi (2012). "What is the Rise of South-South Relations About?: Development, Not Aid." MO* Papers. Brussels: European Centre for Development Policy Management, September 2012, No. 70,1-37. 
Brazilian Ministry of External Relations (2012). Webpage. "Projectos Estruturantes." Accessed December 4, 2016.

http://www.abc.gov.br/Gestao/ProjetosEstruturantes.

Brazilian Ministry of External Relations (July 2007). "South-South Cooperation Activities Carried Out by Brazil." Under - Secretariat General for Cooperation and Trade Promotion. Accessed October 12, 2016.

Brazilian Ministry of Foreign Affairs; Division of the Caribbean for Itamaraty, e-mail communication to author, "Subject: Cooperation Brazil-Haiti." October 5, 2016.

Brazilian Ministry of Foreign Affairs (2015). "Press Release 271: Note of Clarification." Accessed February 22, 2017. http://www.itamaraty.gov.br/en/press-releases/13456-note-of-clarificationhaiti2015.

Brazilian Ministry of Foreign Relations; Brazilian Cooperation Agency (2016). Pesquisa de Projects Online Database. Accessed December 16, 2016. http://www.abc.gov.br/Projetos/pesquisa.

Brazilian Secretariat of Strategic Affairs of the Presidency of the Republic (2014). "Brazilian Cooperation for International Development 2010." Institute for Applied Economic Research (IPEA).

Bruxton, Julia D. (2013). "Swimming Against the Tide: Venezuela and Peace Operations" in South America and Peace Operations: Coming of Age edited by Kai Michael Kenkel, London and New York: Routledge, 171-172.

Bry, Sandra. H. (January 2016). "The Evolution of South-South Development Cooperation: Guiding Principles and Approaches." European Journal of Development Research, 1-16.

Burges, Sean W. (2012). "Developing from the South: South-South Cooperation in the Global Development Game.” Austral: Brazilian Journal of Strategy \& International Relations, 1(2): 225-249.

Burges, Sean W. (2007). "Building a Global Southern Coalition: The Competing Approaches of Brazil's Lula and Venezuela's Chavez." Third World Quarterly, 28(7): 1343-1358.

Bullard, Nicola (2012). "Global South, the Concept of." In Encyclopedia of Global Studies, edited by Mark Juergensmeyer and Helmut K. Anheier. Thousand Oaks, CA: Sage Publications, 724-72. 
Cabral, Lidia and Weinstock, Julia (September 2010). "Brazilian Technical Cooperation for Development." Drivers, Mechanics and Future Prospects. ODI. Accessed November 16, 2015. https://www.odi.org/sites/odi.org.uk/files/odiassets/publications-opinion-files/6137.pdf.

Cabral, Lidia, Russo, Giuliano and Weinstock, Julia ( 2014). "Brazil and the Shifting Consensus on Development Co-operation: Salutary Diversions from the "Aideffectiveness' Trail?.” Development Policy Review, 32(2): 179-202.

Central Intelligence Agency (2016). Haiti. In The World Factbook. Accessed February 15, 2017. https://www.cia.gov/library/publications/the-worldfactbook/geos/ha.html.

Chandran, Rahul and Coooper, Hannah (2015). "Meeting the Challenge of the 20130 Agenda: Alternative Forms of Development Cooperation and the United Nations." United Nations University Centre for Policy Research, November 2015.

Chery, Dady (2015). Hati's Lead Export: Brazil's New Slaves." Global Research Centre for Reesearch on Globalization, December 19, 2015. Accessed February 25, 2017. http://www.globalresearch.ca/haitis-lead-export-brazils-newslaves/5496837.

Chin, Gregory and Quadir, Fahimul (2012). "Introduction: Rising States, Rising Donors and the Global Aid Regime." Cambridge Review of International Affairs, 25(4): 493-506.

Christensen, Steen Fryba (2013). "Brazil's Foreign Policy Priorities." Third World Quarterly, 34(2): 271-286.

Civic Impulse (2016). S. 1104 - 113th Congress: Assessing Progress in Haiti Act of 2014. Accessed December 15, 2016. https://www.govtrack.us/congress/bills/113/s1104.

Costa Vaz, Alcides and Inoue, Cristina Yumie Aoki (2007). "Emerging Donors in International Development Assistance: The Brazil Case," Ottawa: International Development Research Centre Partnership and Business Development Division.

Crassweller, Robert (1971). “Darkness in Haiti.” Foreign Affairs, January 1971 49(2).

Creswell, John W. (2013). Qualitative Inquiry \& Research Design: Choosing Among Five Approaches ( $3^{\text {rd }}$ ed.). Thousand Oaks, CA: Safe Publications, Inc.

Cozendey, Carlos (July 2015). Statement by the Special Envoy of the President of the Federative Republic of Brazil, Ambassador Carlos Cozendey at the Plenary Session of the Third International Conference on Financing for Development. 
Addis Ababa, July 2015. Accessed February 23, 2017.

http://www.un.org/esa/ffd/ffd3/wp-content/uploads/sites/2/2015/07/Brazil.pdf.

Das Gupta, Anirudha and Shahid, A. S. (1981). "Ghana's Non-alignment under Kwame Nkruhma." International Studies, 20(1-2): 1-503.

Dauvergne, Peter and Farias, Deborah B.L. (2012). "The Rise of Brazil as a Global Development Power." Third World Quarterly, 33(5): 903-917.

de Freitas Santos, Roberta and Cerqueira, Mateus Rodrigues (2015). "South-South Cooperation: Brazilian Experiences in South America and Africa." História, Ciências, Saúde - Manguinhos, 22(1), 1-25.

de Renzio, Paolo and Seifert, Jurek (2014). "South-South Cooperation and the Future of Development Assistance: Mapping Actors and Options." Third World Quarterly, 35(10): 1860-1875.

Dexter, Lewis (2006). Elite and Specialized Interviewing. University of Essex, Colchester, UK: ECPR Press - ECPR classics.

Devlin, Robert and FFrench-Dave, Ricardo (1995). "The Great Latin American Debt Crisis: A Decade of Asymmetric Adjustment." Revista de Economia Politica, julho-septembro, 15(3)59.

Dreher, Axel, Nunnenkamp, Peter, and Thiele, Rainer (2011). “Are 'New' Donors Different? Comparing the Allocation of Bilateral Aid between Non-DAC and DAC Donor Countries.” World Development, 39(11): 1950-1968.

Ekström, Karin and Alles, Leonardo (2012). "Brazilian Foreign Policy Under Lula: From Non-intervention to Non-indifference." Political Perspectives, 6(2): 9-29.

Ferreira da Silva, Jorge, da Rocha, Angela, Carneiro, Jorge. (2009). "The International Expansion of Firms from Emerging Markets: Toward a Typology of Brazilian MNEs.” Latin American Business Review, 10:95-115.

Feldman, Andreas, Lengyel, Miguel, Malacalza, Bernabé and Rmalho, Antonio (2011). "Lost in Translation: ABC Cooperation and Reconstruction in Haiti." Journal of Peacebuilding and Development, 6(3): 1- 17; Special Issue, Washington, DC, United States: Center for Global Peace, American University.

Final Communiqué of the Asian-African conference of Bandung (24 April 1955). (n.d.). Centre Virtuel de la Connaissance sur l'Europe (CVCE). Accessed October 14, 2014. http://www.cvce.eu/en/obj/final_communique_of_the_asian_african_conference_ of_bandung_24_april_1955-en-676237bd-72f7-471f-949a-88b6ae513585.html 
Folho de S.Paulo (2008). "Local Report: Lula Vai Levar Empresários ao Haiti Em Maio." April 24, 2008. Accessed February 22, 2017.

http://www1.folha.uol.com.br/fsp/brasil/fc2404200806.htm .

Foreign Policy Magazine (2016). "Fragile State Index." (webpage). Accessed December 27, 2016. http://foreignpolicy.com/fragile-states-index-2016-brexitsyria-refugee-europe-anti-migrant-boko-haram/

Francis, Jill J., Johnston, Marie, Robertson, Clare, Glidewell, Liz, Entwistle, Vikki Ann Eccles, Martin P. and Grimshaw, Jeremy M. (2010). "What is an Adequate Sample Size? Operationalising Data Saturation for Theory-based Interview Studies." Psychology and Health, 25(10): 1229-1245.

Franzosi, Roberto (1987). “The Press as a Source of Socio-Historical Data: Issues in the Methodology of Data Collection from Newspapers." Historical Methods: A Journal of Quantitative and Interdisciplinary History. 20(1): 5-16.

Fues, Thomas (2013). "New Dynamics in South-South Cooperation." German Development Institute. (DIE).

Galletta, Anne (2013). Mastering the Semi-Structured Interview and Beyond: From Research Design to Analysis and Publication. New York, NY: NYU Press.

Gillham, Bill (2000). Developing a Questionnaire. London: Continuum.

Ghosh, Peu (2013). International Relations. Delhi: PHI Learning PVT. LTD.

Global Humanitarian Assistance (2015). Global Humanitarian Assistance Report 2015. Bristol: Global Humanitarian Assistance. Accessed December 16, 2016. http://www.globalhumanitarianassistance.org/wp-content/uploads/2015/06/GHAReport-2015_-Interactive_Online.pdf

Global Humanitarian Assistance (2014). Global Humanitarian Assistance Report 2014. Bristol: Global Humanitarian Assistance. Accessed March 13, 2017. http://www.globalhumanitarianassistance.org/wp-content/uploads/2014/09/GHAReport-2014-interactive.pdf.

Gore, Charles (2013). "The New Development Cooperation Landscape: Actors, Approaches, Architecture." Journal of International Development, 25(6): 769786.

Gosovic, Branislav (2016). "The Resurgence of South-South Cooperation.” Third World Quarterly, 37(4): 733-743.

Gray, Kevin and Gills, Barry K. (2016). "South-South Cooperation and the Rise of the Global South." Third World Quarterly, 37(4): 557-574. 
Gray, Kevin and Murphy, Craig (2013). "Introduction: Rising Powers and the Future of Global Governance." Third World Quarterly, 34(2): 183-193.

Greenburg, Jennifer (2013). "The "Strong Arm" and the "Friendly Hand": Military Humanitarian in Post-earthquake Haiti” Journal of Haitian Studies, 19(1): 95.

Guest, Greg, Bunce, Arwen and Johnson, Laura (2006). "How Many Interviews are Enough? An Experiment with Data Saturation and Variability." Field Methods, 18(1): 59-82.

Hagedoorn, Paulien and Beets, Gijs (October 2011). "New Donor Countries." The Hague: Netherlands Interdisciplinary Demographic Institute \& United Nations Population Fund. Accessed June 26, 2016. http://resourceflows.org/sites/default/files/RF\%20Report\%20New\%20donor\%20c ountries\%20_Oct2011_.pdf.

Haiti Reconstruction Fund (2016). "Pledging Donors," Accessed October 16, 2016. http://www.haitireconstructionfund.org/members.

Haiti Reconstruction Fund (May 2014). “US\$38.6 Million for Budget Support from Haiti Reconstruction Fund," May 28, 2014. Accessed October 16, 2016. http://www.haitireconstructionfund.org/news_en.

Hanson, Gordon H. (2012). "The Rise of Middle Kingdoms: Emerging Economies in Global Trade." The Journal of Economic Perspectives, 26(2): 41-63.

Heine, Jorge and Thompson, Andrew S (2011). Fixing Haiti: MINUSTAH and Beyond. New York: United Nations University Press.

Hirst, Monica (February 2010). "Brazil in Haiti: the Challenges Ahead." Norwegian Peacebuilding Resource Center.

Hirst, Monica and Nasser, Reginaldo Mattar (September 2014). "Brazil's Involvement in Peacekeeping Operations: The New Defence-Security-Foreign Policy Nexus." Norwegian Peacebuilding Resource Centre (NOREF).

Hunt, Alex and Wheeler, Brian (2017). "Brexit: All You Need to Know about the UK Leaving the EU." BBC News. Accessed March 27, 2017.

http://www.bbc.com/news/uk-politics-32810887

IBON International. (2014). Ibon Primer on South-South Cooperation. IBON International. Quezon City, Philippines: IBON International. Accessed November 16, 2015. http://iboninternational.org/resources/14/05/13/ibon-primersouth-south-cooperation 
Inoue, Cristina Yumie Aoki and Costa Vaz, Alcides (2012). "Brazil as 'Southern donor': Beyond Hierarchy and National Interests in Development Cooperation?." Cambridge Review of International Affairs, 25(4): 507-534.

Janus, Heiner, Klingebiel, Stephen and Paulo, Sebatian (2014). "Beyond Aid: A Conceptual Perspective on the Transformation of Development Cooperation." Journal of International Development. Published online: DOI: 10.1002/jid.3045.

Kenkel, Kai Michael (2013). "Out of South America to the Globe: Brazil's Growing Stake in Peace Operations" in South America and Peace Operations: Coming of Age edited by Kai Michael Kenkel, London and New York: Routledge.

Kindornay, Shannon and Samy, Yiagadeesen (2012). "Establishing a Legitimate Development Cooperation Architecture in the Post-Busan Era," North-South Institute. Accessed December 16, 2017. http://www.nsiins.ca/publications/establishing-a-legitimate-development-co-operationarchitecture-in-the-post-busan-era/.

Kligerman, Maxwell, Walmer, David and Merrell, Sylvia. Bereknyei (November 2015). "The Socioeconomic Impact of International Aid: A Qualitative Study of Healthcare Recovery in Post-earthquake Haiti and Implications for Future Disaster Relief." Global Public Health, 1-14.

Kohlbacher, Florian (January 2006). "The Use of Qualitative Content Analysis in Case Study Research.” Forum Qualitative Sozialforschung/Forum: Qualitative Social Research, 7(1) Article 2, Accessed July 28, 2016. http://www.qualitativeresearch.net/index.php/fqs/article/view/75/153.

Krüger, Lydia, "North-North, North-South and South-South Relations," in Global Transformation and World Futures: Knowledge, Economy, and Society, 1 edited by Sohail Inayatulah, Oxford: EOLSS Publishers.

Least Developed Countries Ministerial Conference 2013 (2013). "Issues Paper: From the Instanbul Programme of Action to the world We Want in 2015 and Beyond: Implementing the UNIDO Operation Strategy.” Accessed November 26, 2016. http://www.unido.org/fileadmin/user_media_upgrade/Media_center/2013/News/L DC_2013/2013_UNIDO_LDC_issues_paper.pdf.

Machado, Renato (2012). "OAS Paralisa Obra no Haiti e Quer Receber Indenizaçã." Folho de S.Paulo, September 1, 2012. Accessed on February 22, 2017. http://www1.folha.uol.com.br/fsp/mundo/63899-oas-paralisa-obra-no-haiti-equer-receber-indenizacao.shtml. 
Malagon-Maldonado, Gabriella (2014). "Qualitative Research in Health Design." HERD: Health Environments Research \& Design Journal, 7(4): 120-134.

Malik, Khalid (2013). "Human Development Report 2013: The Rise of the South: Human Progress in a diverse world." The Rise of the South: Human Progress in a Diverse World (March 15, 2013). UNDP-HDRO Human Development Reports.

Manning, Richard (2006). "Will 'Emerging Donors' Change the Face of Internatioal Coopertation?.” Development Policy Review, 24(4): 371-385.

Marcondes de Souza Neto, Danilo (2013). "Regional Defense Integration and Peacekeeping Cooperation in the Southern Cone" in South America and Peace Operations: Coming of Age edited by Kai Michael Kenkel, London and New York: Routledge, 68.

Marroni de Abreu, Fernando Jose’ (2013). “A Evolução da Cooperação Técnica Internacional no Brasil." Mural International, 1(2): 3-16.

Marshall, Catherine, and Rossman, Gretchen. B. (2014). Designing Qualitative Research. Thousand Oaks, CA: Sage.

Mattos, Litza (2014). "Minas Gerais Recebe 3.000 Imigrantes do Haiti por Ano.” O Tempo, May 17, 2014. Accessed February 25, 2017. http://www.otempo.com.br/capa/mundo/minas-gerais-recebe-3-000-imigrantesdo-haiti-por-ano-1.846891.

Mawdsley, Emma (2011). "The Changing Geographies of Foreign Aid and Development Cooperation: Contributions from Gift Theory." Transactions of the Institute of British Geographers. 37(2): 256-272.

Mawdsley, Emma., Savage, Laura. and Kim, Sung-Mi (2012). “A 'Post-Aid World'? Paradigm Shift in Foreign Aid and Development Cooperation at the 2011 Busan High Level Forum." The Geographical Journal, 180(1): 22-38.

Mayring, Philip (2014). Qualitative Content Analysis: Theoretical Foundation: Basic Procedures and Software Solution. Accessed July 22, 2016. http://nbnresolving.de/urn:nbn:de:0168-ssoar-395173.

Milani, Carlos. R. S. and Echart Muñoz, Enara (2013). "Does the South challenge the Geopolitics of International Development Cooperation?." Geopolitica(s). Revista de Estudios Sobre Espacio y Poder. 4(1): 35-41.

Ministry of External Affairs; Government of India (2012). "History and Evolution of Non-Aligned Movement.” Accessed October 20, 2014. https://mea.gov.in/infocus-article.htm?20349/History+and+Evolution+of+NonAligned+Movement 
Mintz, Sidney W. (1995). Can Haiti Change? Foreign Affairs, January/February 1995 $74(1)$.

Mohan, Giles (2016). "Emerging Powers in International Development: Questioning South-South Cooperation." In The Palgrave Handbook of International Development, Palgrave Macmillan UK, 279-296.

Morais de Sa e Silva, Michelle (2010). "How Did We Get Here? The Pathways of SouthSouth Cooperation" in "South-South Cooperation? The Same Old Game or a New Paradigm?." Poverty in Focus edited by Rathin Roy and Melissa Andrade, International Policy Centre for Inclusive Growth, Bureau for Development Policy, UNDP, 25: 3-4.

Moulin, Carolina and Thomaz, Diana (2016). "The Tactical Politics of 'Humanitarian' Immigration: Negotiation Stasis, Enacting Mobility." Citizenship Studies, 20(5): 595-609.

Muhr, Thomas (2016). "Beyond 'BRICS': Ten Theses on South-South Cooperation in the Twenty-First Century." Third World Quarterly, 37(4): 630-648.

Napoleão, Thomaz and Kalil, Mariana (2015). "Stabilization as the Security of Peacebuilding? The Experience of Brazil and MINUSTAH in Haiti.” Brasiliana Journal for Brazilian Studies, 3(2). Accessed on December 27, 2017. http://ojs.statsbiblioteket.dk/index.php/bras/article/view/19998/18191.

New York Times (2017). “Mr. Trump's Island Mentality.” Sunday Review. March 5, 2017, 166(57527): 12. Accessed March 27, 2017. https://www.nytimes.com/2017/03/04/opinion/sunday/president-trumps-islandmentality.html?_r=0

Nieto, W. Alejandro Sánchez (2012). "Brazil's Grand Design for Combining Global South Solidarity and National Interests: A Discussion of Peacekeeping Operations in Haiti and Timor." Globalizations, 9(1): 161-178.

O Globo (2011). "Na posse, Celso Amorim defende retirada de tropas brasileiras no Haiti." August 8, 2011. Acceessed February 15, 2017. http://g1.globo.com/jornal-nacional/noticia/2011/08/na-posse-celso-amorimdefende-retirada-de-tropas-brasileiras-no-haiti.html.

O'Connor, Daniel, Brisson-Boivin, Kara and Ilcan, Suzan (2014). "Governing Failure: Development, Aid and Audit in Haiti." Conflict, Security \& Development, 14(3): 309-330. 
Organisation for Economic Cooperation and Development (OECD) (2016). "Statistics on Resource Flows to Developing Countries." (webpage). Accessed December $16,2016$. http://www.oecd.org/dac/stats/statisticsonresourceflowstodevelopingcountries.ht $\mathrm{m}$.

Organisation for Economic Cooperation and Development. (2014). "Non-DAC Countries and the Debate on Measuring Post-2015 Development Finance. DAC Meeting, February 10, 2014.” Accessed November 26, 2014. http://www.oecd.org/dac/dac-global-relations/NonDAC\%20countries\%20and\%20the\%20debate\%20on\%20measuring\%20post2015\%20development\%20finance.pdf.

Organisation for Economic Co-operation and Development (OECD) (2013). Perspectives on Global Development 2013 Industrial Policies in a Changing World: Shifting up a Gear. Accessed October 29, 2016. http://www.oecd.org/dev/pgd/COMPLETE-\%20Pocket\%20EditionPGD2013.pdf.

Organisation for Economic Co-operation and Development (OECD) ( November 2008). "Factsheet: Is it ODA?." OECD.org. Accessed July 21, 2014, from http://www.oecd.org/investment/stats/34086975.pdf

Organisation for Economic Co-operation and Development (OECD) (2006). "DAC in Dates: The History of OECD's Development Assistance Committee." Access July 28, 2014. http://www.oecd.org/dac/1896808.pdf.

Organisation for Economic Co-operation and Development (OECD) (n.d.). Official development assistance - definition and coverage. OECD.org. Accessed July 21, 2014, from http://www.oecd.org/investment/stats/officialdevelopmentassistancedefinitionand coverage.htm.

Organisation for Economic Co-operation and Development (OECD) (n.d.). "Organisation for European Economic Co-operation." (webpage). Accessed on November 25, 2014.

http://www.oecd.org/general/organisationforeuropeaneconomiccooperation.htmhttp://www.oecd.org/general/organisationforeuropeaneconomiccooperation.htm.

Organisation for Economic Co-operation and Development (OECD). (n.d.). "History of DAC Lists of Aid Recipient Countries." (webpage). Access on November 25, 2014. http://www.oecd.org/dac/stats/historyofdaclistsofaidrecipientcountries.htm\#Origi ns. 
Önis, Ziya (2016). "Democracy in Uncertain Times: Inequality and Democratic Development in the Global North and Global South." METU Studies in Development, 43(1): 317-336.

Partners in Population Development (n.d.). "Chapter 1, South-South Cooperation: A Pathway for Development." Accessed November 20, 2014. http://www.partnerspopdev.org/publication/ppd-handbook/.

Perales, José Raúl (2011). "Haiti and the Regional Dynamics of International Cooperation" in Fixing Haiti: MINUSTAH and Beyond edited by Jorge Heine and Andrew S. Thompson. New York: United Nations University Press.

Pinheiro, Leticia and Giao, Gabrieli (2014). "Cooperation for Development, Brazilian Reginal Leadership and Global Protagonism." Journal of the Brazilian Political Science Association, 8(2): 8-30.

Potter, William and Mukhatzhanova, Gaukhar (2012). Nuclear Politics and the NonAligned Movement: Principles vs Pragmatism. Milton Park, Abingdon, Oxon: Routledge for the International Institute for Strategic Studies.

Quadir, Fahimul (2013). "Rising Donors and the New Narrative of 'South-South' Cooperation: What Prospects for Changing the Landscape of Development Assistance Programmes?" Third World Quarterly, 34(2): 321-338.

Ramachandran, Vijaya and Walz, Julie (2015). "Haiti: Where Has all the Money Gone?.” Journal of Haitian Studies, 21(1): 26-65.

Rathod, Jayesh and Granja, João Guilherme Casagrande (2016). "U.S. Can Learn from Brazil about Haitian Migration." Orlando Sentinel. December 10, 2016. Accessed February 21, 2017. http://www.orlandosentinel.com/opinion/os-edhaiti-migration-lessons-from-brazil-121016-2-20161210-story.html.

Reuters (September 2015). "Countries Pledge 40,000 U.N. Peacekeepers at U.N. Summit.” September 28, 2015. Accessed December 27, 2017. http://www.reuters.com/article/us-un-assembly-peacekeepersidUSKCNORS2E420150929.

Reuters (May 2010), "Brazil Pays First Donation into Haiti Quake Fund.” Haiti Reconstruction Fund, May 11, 2010. Accessed December 16, 2017. http://www.haitireconstructionfund.org/news0511.

Reisman, W. Michael (1995). "Haiti and the Validity of International Action," Faculty Scholarship Series, Paper 884. 
Richey, Lisa Ann and Ponte, Stefano (2014). "New Actors and Alliances in Development." Third World Quarterly, 35(1): 1-21.

Robledo, Carmen (2015). "New donors, Same Old Practices? South-South Cooperation of Latin American Emerging Donors." Bandung: Journal of the Global South, 2(3), 1-16.

Rogers, David (2015). "Major Power Boost for Haiti as Chinese Firm Agrees to Finance \$240m Dam." Global Construction Review, February 10, 2015. Accessed December 16, 2016. http://www.globalconstructionreview.com/news/majorpower-boost-haiti-chi8ne8s8e-f8i8r8m-a8gr8ee/.

Romero, Simon and Zarate, Andrea. (2012). "Influx of Haitian into the Amazon Prompts Immigration Debate in Brazil." New York Times. http://www.nytimes.com/2012/02/08/world/americas/brazil-limits-haitianimmigration.html.

Rowlands, Dane (2012). "Individual BRICS or a Collective Bloc? Convergence and Divergence amongst 'Emerging Donor' Nations." Cambridge Review of International Affairs. 25(4): 629-649.

Rosseel, Peter, De Corte, Erik, Blommaert, Jan and Verniers, Elke (2009). “Approaches to North-South, South-South and North-South-South Collaboration: A Policy Document." Ku Leuven. Accessed November 26, 2014. https://lirias.kuleuven.be/handle/123456789/229636.

Roy, Rathin, and Andrade, Melissa (2010). "South-South Cooperation? The Same Old Game or a New Paradigm?." Poverty in Focus. International Policy Centre for Inclusive Growth, Bureau for Development Policy, UNDP, 25: 1-25.

Sanahuja, José Antonio (2010). "Post-liberal regionalism: S-S Cooperation in Latin America and the Caribbean in South-South Cooperation? The Same Old Game or a New Paradigm?," in "South-South Cooperation? The Same Old Game or a New Paradigm?." Poverty in Focus edited by Rathin Roy and Melissa Andrade, International Policy Centre for Inclusive Growth, Bureau for Development Policy, UNDP, 25: 17-19.

Santiso, Javier (2013). The Decade of the Multilatinas. Cambridge: Cambridge University Press.

Santos, Rita and Cravo, Teresa Almeida (2014). "Brazil's Rising Profile in United Nation Peacekeeping Operations since the End of the Cold War." Norwegian Peacebuilding Resource Centre (NOREF).

Shakur, Tupac Amaru (1992). “Tupac Calls Out Trump's Greed in this Unseen 1992 MTV Interview.” Accessed February 10, 2017. 
http://www.mtv.com/news/2870384/tupac-calls-out-trumps-greed-in-this-unseen1992-mtv-interview/.

Sinha, Pranay and Hubbard, Michael (2012). "How Does the Existence of IATI shape the Dynamics of Emerging Donors under South-South Cooperation?." University of Birmingham, International Development Department. Accessed July 26, 2016. http://www.birmingham.ac.uk/Documents/college-social-sciences/governmentsociety/idd/research/aid-data/chapter3.pdf.

Shurtleff, William and Aoyagi, Akiko (2015). History of Soybeans and Soy Foods in Eastern Europe (Including All of Russia) (1783-2015). Soy Center. Accessed December 16, 2016. http://www.soyinfocenter.com/books/189.

Six, Clemons (2009). The Rise of Postcolonial States as Donors: A Challenge to the Development Paradigm?. Third World Quarterly, 30(6): 1103-1121.

Smith, Kerry (2011). "Non-DAC Donors and Humanitarian Aid: Shifting Structures, Changing Trends." Global Humanitarian Assistance. UK: Development Initiatives, 1-25.

Snyder, Glenn H. and Diesing, Paul (1977). Conflict among Nations, Bargaining, Decision Making and Systems Structure in International Crisis. New Jersey: Princeton University Press.

Sotomayor Velazquez, Arturo C. (2013). "Democratization and Commitment to Peace: South America's Motivations to Contribute to Peace Operations." in South America and Peace Operations: Coming of Age edited by Kai Michael Kenkel, London and New York: Routledge, 45-63.

Sparkle, Matthew (2007). "Everywhere but Always Somewhere: Critical Geographies of the Global South." The Global South. 1(1): 117-126.

Stuenkel, Oliver. (May 2013). "Institutionalizing South-South Cooperation: Towards a New Paradigm? Background Research Paper Submitted to the High Level Panel on the Post-2015 Development Agenda." Accessed November 26, 2014. http://www.post2015hlp.org/wpcontent/uploads/2013/05/Stuenkel_Institutionalizing-South-South-CooperationTowards-a-New-Paradigm.pdf.

Tan, See Seng and Acharya, Amitav (2008). Bandung Revisited: The Legacy of the 1955 Asian-African Conference for International Order. Singapore: NUS Press, National University of Singapore. 
Taylor, Steven J., Bogdan, Robert and DeVault, Marjorie (2015). Introduction to Qualitative Research Methods: A Guidebook and Resource. Hoboken, NJ: John Wiley \& Sons.

The Reality of Aid (2010). "South-South Development Cooperation: A Challenge to the Aid System?." The Reality of Aid Management Committee, 1-22. Accessed October 14, 2016. http://www.realityofaid.org/roa_report/south-southdevelopment-cooperation-a-challenge-to-the-aid-system/

Trivedi, Sonu. (2005). Handbook of International Organizations. New Delhi: Atlantic Publishers and Distributors.

Troilo, Pete. (2012). "Setting Its Own Course, Brazil Foreign Aid Expands and Evolves." DEVEX. Accessed January 20, 2017.

https://www.devex.com/news/setting-its-own-course-brazil-foreign-aid-expandsand-evolves-78631.

Truman, Harry (1949). “Inaugural Address.” Speech, Washington, DC, January 20, 1949. Harry S. Truman Library and Museum. Accessed November 26, 2015. http://library.menloschool.org/chicago/speech.

Ugwuja, Alex A., Ubaku, Kelechi C. Obiakor, Nwachukwu J. and Ibekilo, Bruno (2014). "South-South Cooperation and the Prospects of a New International Economic Order: An Insight into the India Brazil-South Africa (IBSA) Dialogue Forum." International Journal of Humanities Social Sciences and Education (IJHSSE), 1(8): 171-182.

United Nations. (2011). The State of South-South Co-operation: Report of the Secretary-General, A/66/229. Accessed November 16, 2015. http://www.preventionweb.net/files/resolutions/N1144233.pdf.

United Nations Conference on Trade and Development (UNCTAD) (2010). "Economic Development in Africa Report 2010: South-South Cooperation - Africa and the New Forms of Development Partnership." United Nations Publication. Accessed November 16, 2016.

http://unctad.org/en/Pages/Publications/EconomicDevelopmentinAfricaseries.asp $\mathrm{x}$.

United Nations Development Program (UNDP) (2008). Executive Summary SouthSouth Cooperation - Concepts, Typology and Challenges United Nations System / Brazil. Accessed November 16, 2016. http://rss.cebri.org/213.pdf.

United Nations Office of the High Representative for the Least Developed Countries, Landlocked developing countries and small island developing states (OHRLLS) (2011). "Harnessing the Positive Contribution of South-South Co-operation for 
Least Developed Countries' Development in New Delhi” Fourth United Nations Conference on the Least Developed Countries Background Paper, 18-19 February 2011. 6. Accessed November 28, 2014.

http://www.un.org/en/conf/ldc/pdf/background\%20paper\%20on\%20southsouth $\% 20$ cooperation $\% 20$ for $\% 201 d c s \% 20$ development-final.pdf.

United Nations Peacekeping (n.d.). "Peacekeeping Operations." (webpage access). Accessed January 4, 2017. http://www.un.org/en/peacekeeping/operations/.

United Nations Security Council (2016). "Resolution 2313, The Question Concerning Haiti," Adopted by the Security Council at its $7790^{\text {th }}$ meeting on October 13, 2016. Accessed December 14, 2016. http://unscr.com/en/resolutions/2313.

United Nations Security Council (2015). "Resolution 2243 (2015)," Adopted by the Security Council at its $7534^{\text {th }}$ Meeting, on October 14, 2015. Accessed December 14, 2016. http://www.un.org/en/peacekeeping/documents/minustahres2243.pdf.

United Nations Security Council (2012). "Resolution 2070," Adopted by the Security Council at its $6845^{\text {th }}$ Meeting, on October 12, 2012. Accessed December 14, 2016. http://www.un.org/en/ga/search/view_doc.asp?symbol=S/RES/2070(2012).

United States Agency for International Development (USAID). (2011). USAID Policy Framework 2011- 2015. Washington, D.C.: USAID.

United States Department of State; Office of the Historian "U.S. Invasion and Occupation of Haiti, 1915-34.” (webpage). Accessed February 21, 2017. https://history.state.gov/milestones/1914-1920/haiti

Van Bilzen, Gerard (2015). The Develpoment of Aid. Newcastle upon Tyne, UK: Cambridge Scholars Publishing.

Vazquez, Karin (2013). "Enhancing Management Practices in the South: Study on Country-Led Practices." United Nations Office for South-South Cooperation. New York: United Nations Office for South-South Cooperation. Accessed September 28, 2016. http://tcdc2.undp.org/GSSDAcademy/ResourceCentre/docs/SSC_Case_Designed _Web.pdf.

Vieira, Marco Antonio and Alden, Chris (2011). "India, Brazil, and South Africa (ISBA): South-South Cooperation and the Paradox of Regional Leadership." Global Governance, 17: 507-528.

Vijaya Ramachandran and Julie Walz. 2012. "Haiti: Where Has All the Money Gone?" CGD Policy Paper 004. Washington, D.C.: Center for Global Development. 
Accessed December 27, 2016.

http://www.cgdev.org/content/publications/detail/1426185.

Waltz, Kenneth N. (1979). Theory of International Politics. Boston, MA: McGrawHill. 79-106.

Wendt, Alexander (1992). "Anarchy is What States Make of It: The Social Construction of Power Politics." International Organization, 46(2).

Willis, Katie (2006). "Chapter 15: Interviewing" in Doing Development Research. edited by Vandana Desai, and Robert B. Potter. London: Sage, 144-152.

Woods, Ngaire (2008). "Whose Aid? Whose Influence? China, Emerging Donors and the Silent Revolution in Development Assistance." International Affairs, 84(6): 1205-1221.

World Bank (2017). “Haiti Overview.” (webpage). Accessed February 27, 2017. http://www.worldbank.org/en/country/haiti/overview\#1.

World Bank (2016). "Haiti Reconstruction Fund Financial Report Prepared by the Trustee as of September 30, 2016." Accessed December 16, 2016. http://www.haitireconstructionfund.org/documents/steering_committee/en.

World Bank. (2012). Global Monitoring Report 2012: Food Prices, and the Millennium Development Goals (MDGs). Accessed July 15, 2016. http://www.imf.org/external/pubs/ft/gmr/2012/eng/gmr.pdf.

World Bank (2010). "Press Release: Brazil becomes the First Country to Country to Contribute to Haiti Reconstruction Fund." May 11, 2010. Accessed February 24, 2017. http://www.worldbank.org/en/news/press-release/2010/05/11/brazilfirst-country-contribute-haiti-reconstruction-fund.

World Concern (2011). "Haiti Earthquake Facts and Figures." (webpage). Accessed Janary 20, 2017. http://reliefweb.int/report/haiti/haiti-earthquake-facts-andfigures.

Xalma, Cristina. (2013). "The New Boom in South-South Cooperation: The Experience of Ibero-America." Institute for the Integration of Latin America and the Caribbean @ Journal. January-June 2013.,( 36)17: 25-38.

Yazdani, Mariam, Bercovitch, Daniela and Charles-Voltaire, Jane (2014). "Knowledge Transfer on Urban Violence: From Brazil to Haiti. Environment \& Urbanization. International Institute for Environment and Development (IIED). 26(2): 457468. 
Yin, Robert K. (2014). Case Study Research: Design and Methods. Thousand Oaks, CA: Sage.

Yin, Robert K. (1981) “The Case Study Crisis: Some Answers.” Administrative Science Quarterly, 26: 58-65.

Zhou, Yiping (October 2010). The Future of South-South Development Assistance and the Role of the UN. Speech presented to the OECD Meeting of National Focal Points for Policy Coherence for Development, Paris, France. Accessed June 11, 2014. http://www.oecd.org/development/pcd/46188961.pdf. 


\section{APPENDIX I}

Interview Questions

Benefits:

1. What are some of the main benefits of South-South cooperation between Brazil and Haiti?

2. What are the political benefits of South-South cooperation between Brazil and Haiti?

3. How is successful development determined within the Haiti-Brazilian cooperation framework?

4. How significant has Brazilian technical cooperation versus other types of cooperation ie. financial assistance been for Haiti?

5. How sustainable are development cooperation activities and projects between Brazil and Haiti?

6. What are the main incentives driving Brazil-Haiti cooperation given ongoing efforts to overcome severe development challenges?

7. Overall, what are the significant strengths of Brazil-Haiti cooperation for Haiti/Brazil?

Challenges:

1. How does the unique history of Haiti contribute to the challenges for continuing a Brazil-Haiti framework of South-South cooperation from the perspective of your country?

2. What are some of the main challenges of South-South cooperation between Brazil and Haiti?

3. What are the political, economic, and social barriers in implementing South-South cooperation framework for Brazil and Haiti?

4. What are the cultural barriers that can impede the success of South-South cooperation framework for Brazil and Haiti?

5. What role does Haiti's relationship with other LAAC countries, Northern states and multilateral institutions challenge Brazil-Haiti cooperation?

6. It is understood that states in the Global South who engage in South-South cooperation do not follow traditional reporting and evaluation mechanisms: How challenging is this for the Brazil-Haiti framework?

7. Overall, what are the significant weakness of Brazil-Haiti cooperation for Haiti/Brazil?

Strategic:

1. What's the strategic reasoning for the application of South-South cooperation to Brazil and Haiti?

2. Which types of development cooperation activities are the most successful? What are the main lessons and drivers of South-South cooperation between Brazil and Haiti? 
3. In your opinion, what makes South-South cooperation an alternative development strategy to Northern assistance for countries of the South?

4. What is the political strategy behind South-South cooperation between Brazil and Haiti?

5. What is the economic strategy behind South-South cooperation between Brazil and Haiti? In what ways does the South-South cooperation framework expand competition and choice for recipient countries like Haiti?

6. What is the social strategy behind South-South cooperation between Brazil and Haiti?

7. How is it in Haiti and Brazil's best interest to engage in South-South cooperation framework? In what ways is it rational and in their national interest? 


\section{APPENDIX II}

Survey Questionnaire

\begin{tabular}{|l|l|}
\hline \multicolumn{1}{|c|}{ QUESTIONS } & \\
\hline $\begin{array}{l}\text { What is your opinion on South-South } \\
\text { cooperation framework? }\end{array}$ & \\
\hline $\begin{array}{l}\text { How does Brazil benefit from } \\
\text { engaging in South-South cooperation } \\
\text { framework with Haiti? }\end{array}$ & \\
\hline $\begin{array}{l}\text { How does Haiti benefit from } \\
\text { engaging in South-South cooperation } \\
\text { framework with Brazil? }\end{array}$ & \\
\hline $\begin{array}{l}\text { How challenging is South-South } \\
\text { cooperation framework for Brazil? }\end{array}$ & \\
\hline $\begin{array}{l}\text { How challenging is South-South } \\
\text { cooperation framework for Haiti? }\end{array}$ & \\
\hline $\begin{array}{l}\text { How is engaging in South-South } \\
\text { cooperation framework strategic for } \\
\text { Brazil? }\end{array}$ \\
\hline $\begin{array}{l}\text { How is engaging in South-South } \\
\text { Haition framework strategic for }\end{array}$ \\
\hline
\end{tabular}




\section{APPENDIX III}

Institutional Review Board Letter

\section{MEMORANDUM}

To:

CC:

From:

Date:

Protocol Title:
Dr. Eduardo Gamarra

Maria Melendez-Vargas, MIBA, IRB Coordinator

October 23, 2015

"South-South Cooperation as an Altemative Development Strategy.

Rethinking Development through South-South Cooperation in Latin

America"

The Florida Intemational University Office of Research Integrity has reviewed your research study for the use of human subjects and deemed it Exempt under 46.101(b) (1) of the Common Rule via the Exempt Review process.

IRB Protocol Exemption \#: IRB-15-0385

IRB Exemption Date: $10 / 22 / 15$

TOPAZ Reference \#: 103932

As a requirement of $I R B$ Exemption you are required to:

1) Submit an Event Form and provide immediate notification of:

- Any additions or changes in the procedures involving human subjects.

- Every serious or unusual or unanticipated adverse event as well as problems with the rights or welfare of the human subjects.

2) Submit a Project Completion Report Form when the study is finished or discontinued.

Special Conditions: N/A

For further information, you may visit the IRB website at http://research.fiu.edu/irb. 
VITA

KAREN CLAY

1988-1992

1992-1993

1998-1999

1998-1999

$1998-1999$

1999-2000

2001-2003

2004-2011

2009-2014

2014-2017
B.A., Political Science

Texas A \& M University

College Station, Texas

Master of Public Administration

Texas A \& M University

College Station, Texas

Educational Specialist in International Education

New York University

New York, New York

Graduate Assistant

Metropolitan Center for Urban Education

New York, New York

Intern

New York City Commission for the United Nations

Consular Corps and Protocol

New York, New York

International Affairs Specialist

Market Intelligence and Political Risk at ENRON

Houston, Texas

Consultant; International Education Programs

Images of Mare Literacy Project \& Quilombo Niger Okan

Intervention Specialist

Miami Dade College

Miami Florida

M.A., International Studies

Florida International University

Miami, Florida

Doctoral Candidate

Florida International University

Miami, Florida 
2011-2016

Global STEM Program Manager

Spelman College

Atlanta, GA

2016-present

Assistant Director for Study Abroad

Spelman College

Atlanta, GA

\section{PUBLICATIONS AND PRESENTATIONS}

Clay, K. Recruiting and Retaining STEM Students into International Research Experiences: Best Practices for Working with Under-Represented Groups. Presented at Georgia International Educators--Tennessee International Educators Bi-State Conference. Chattanooga, TN, February, 20, 2014.

Clay, K. GSTEM: Advancing International Research Opportunities for STEM Students at Spelman College. Poster presented at Innovation Through Institutional Integration: Improving the Undergraduate STEM Experience, Washington, DC, March 13, 2014.

Clay, K. Global Undergraduate Research: Enhancing Knowledge. Paper presented at the National Council on Undergraduate Research (NCUR). Lexington, KY, April, 3, 2014.

Clay, K. "The G-STEM Model for Enhancing Global Research in the STEM Disciplines." Poster presented at the Faculty Resource Network (FRN) 2014 National Symposium; San Juan, Puerto Rico, November 22, 2014.

Togunde, D., McCormack, K., Galvao, T., Clay, K. "The Spelman Model for Enhancing Global Research in the STEM Disciplines," IMPACT Arcadia University. 2015.

Chapter contributor on the Global STEM Program in STEM and Social Justice: Teaching and Learning in Diverse Settings-A Global Perspective. Developed the $S^{3}$ Model for the Successful Recruitment and Retention of African American Students in to International Research Experience. Expected 2017. 